UNIVERSIDAD DE SALAMANCA

FACULTAD DE BIOLOGÍA
DEPARTAMENTO DE BIOLOGÍA

CELULAR Y PATOLOGÍA

ÁREA DE BIOLOGÍA CELULAR

VNIVERSiDAD

DSALAMANCA

\title{
Expresión de proteínas ligantes de calcio durante la ontogenia del Sistema Nervioso Central de teleósteos
}

Angel Fernando Porteros Herrero 
José Aijón Noguera, Catedrático de Citología e Histología Vegetal y Animal de la Facultad de Biología de la Universidad de Salamanca, Director del Departamento de Biología Celular y Patología

\section{CERTIFICO:}

Que el presente trabajo titulado "Expresión de proteínas ligantes de calcio durante la ontogenia del Sistema Nervioso Central de teleósteos", ha sido realizado en el Departamento de Biología Celular y Patología, bajo la dirección de los Profs. Dres. Alonso Peña y Arévalo Arévalo, y considero que reúne las condiciones necesarias para ser defendido en nuestra Universidad y optar al título de Doctor en Biología.

Salamanca, Abril de 1997 
Quiero expresar mi más sincero agradecimiento

- Al Prof. Dr. D. José Aijón, por haberme concedido la oportunidad de realizar esta Tesis Doctoral y haber facilitado en todo momento el desarrollo de mi trabajo.

- Al Prof. Dr. D. José Ramón Alonso y a la Profa. Dra. Dña. Rosario Arévalo, directores de esta Tesis, por su continua ayuda y preocupación, robando tiempo a sus propias ocupaciones y a su descanso, así como por sus enseñanzas, aliento, paciencia y comprensión.

- Al Prof. Dr. D. Juan Lara, por el interés demostrado durante la elaboración de este trabajo y sus comentarios siempre acertados.

- A mis compañeros del área de Biología Celular del Departamento de Biología Celular y Patología, por su ayuda y amistad.

- Al Prof Dr. D. Ricardo Vázquez y al Prof. Dr. D. Eliseo Carrascal por haberme permitido utilizar el equipo de las Unidades de Anatomía C e Histología del Departamento de Anatomía e Histología Humanas de la Universidad de Salamanca.

- Al Dr. D. Juan Carlos Velasco y a D. Juan José Pérez-Regadera, así como al personal de las piscifactorias de Galisancho (Salamanca) y Vegas del Guadiana (Badajoz) por las facilidades brindadas en la obtención de los animales de experimentación.

- A mi familia.

- Al Ministerio de Educación y Ciencia (beca predoctoral AP-92), la DIGYT (PB941388), la Junta de Castilla y León y la Universidad de Salamanca cuyas subvenciones han hecho posible la realización de la presente Tesis Doctoral. 


\section{ÍNDICE}

\section{INTRODUCCIÓN}

ONTOGENIA DEL SISTEMA NERVIOSO CENTRAL DE VERTEBRADOS

MORFOGÉNESIS DEL SISTEMA NERVIOSO CENTRAL DE PECES TELEÓSTEOS

Telencéfalo

Diencéfalo

Mesencéfalo

Metencéfalo

Mielencéfalo

Médula espinal

EL CALCIO DURANTE EL DESARROLLO

PROTEÍNAS LIGANTES DE CALCIO

Parvalbúmina

Calbindina D-28k

Calretinina

JUSTIFICACIÓN Y OBJETIVOS

\section{MATERIAL Y MÉTODOS}

MATERIAL

MÉTODOS

FIJACIÓN

CORTE

PROCESAMIENTO DE EMBRIONES IN TOTO

TÉCNICA INMUNOCITOQUÍMICA EN SECCIONES DE TEJIDO

TÉCNICA INMUNOCITOQUíMICA IN TOTO

CONTROLES DE LA REACCIÓN INMUNOCITOQUÍMICA

ESPECIFICIDAD DE LOS ANTICUERPOS

Calbindina D-28k

Parvalbúmina

Calretinina

TINCIONES HISTOLÓGICAS BÁSICAS

DOCUMENTACIÓN

\section{RESULTADOS}

\section{A) DESCRIPCIÓN DE LOS RESULTADOS}

DESCRIPCIÓN GENERAL DEL SISTEMA NERVIOSO CENTRAL DE LA TRUCHA ARCO IRIS 
Telencéfalo

Diencéfalo

Mesencéfalo

Metencéfalo

Mielencéfalo

Médula espinal

CALRETININA

Telencéfalo

Diencéfalo

Mesencéfalo

Metencéfalo

Mielencéfalo

Médula espinal

PARVALBÚMINA

Telencéfalo

Diencéfalo

Mesencéfalo

Metencéfalo

Mielencéfalo

Médula espinal

CALBINDINA D-28K

Telencéfalo

Diencéfalo

Mesencéfalo

Metencéfalo

Mielencéfalo

Médula espinal

\section{B) ICONOGRAFÍA}

LISTA DE ABREVIATURAS

FIGURAS

\section{DISCUSIÓN}

PROTEÍNAS LIGANTES DE CALCIO EN LA ONTOGENIA DEL SISTEMA NERVIOSO DE LA TRUCHA ARCO IRIS

INMUNORREACTIVIDAD PARA PROTEÍNAS LIGANTES DE CALCIO EN EL SISTEMA NERVIOSO DE PECES TELEÓSTEOS

Distribución de calbindina D-28k

Distribución de calretinina

Distribución de parvalbúmina 


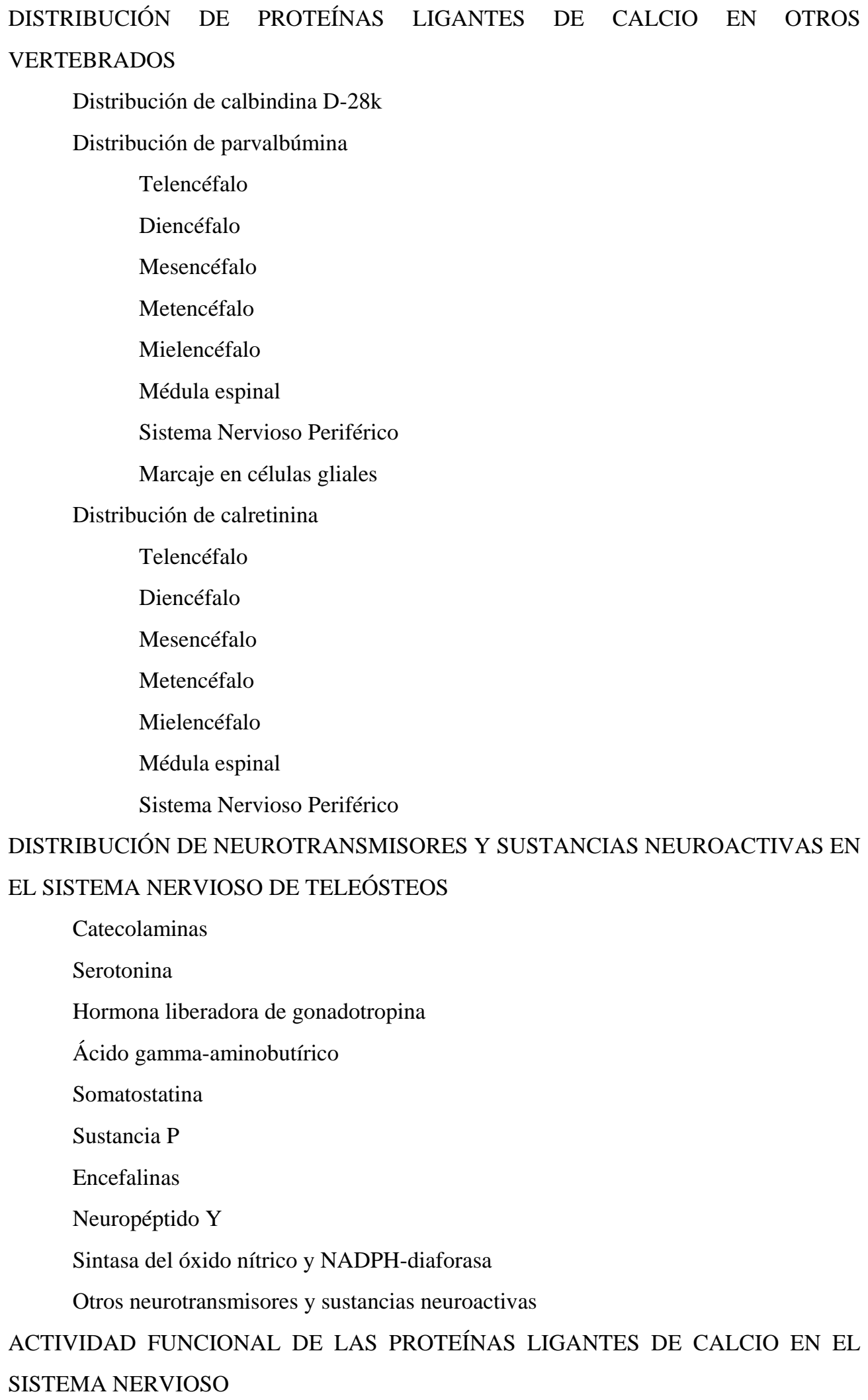

Distribución de calbindina D-28k

Distribución de parvalbúmina

Telencéfalo

Diencéfalo

Mesencéfalo

Metencéfalo

Mielencéfalo

Médula espinal

Sistema Nervioso Periférico

Marcaje en células gliales

Distribución de calretinina

Telencéfalo

Diencéfalo

Mesencéfalo

Metencéfalo

Mielencéfalo

Médula espinal

Sistema Nervioso Periférico

DISTRIBUCIÓN DE NEUROTRANSMISORES Y SUSTANCIAS NEUROACTIVAS EN

EL SISTEMA NERVIOSO DE TELEÓSTEOS

Catecolaminas

Serotonina

Hormona liberadora de gonadotropina

Ácido gamma-aminobutírico

Somatostatina

Sustancia P

Encefalinas

Neuropéptido Y

Sintasa del óxido nítrico y NADPH-diaforasa

Otros neurotransmisores y sustancias neuroactivas

ACTIVIDAD FUNCIONAL DE LAS PROTEÍNAS LIGANTES DE CALCIO EN EL SISTEMA NERVIOSO

\section{CONCLUSIONES}

\section{BIBLIOGRAFÍA}


Introducción - 1 -

INTRODUCCIÓN 
Se denomina ontogenia al conjunto de procesos que tienen lugar en un organismo de forma continuada desde la fecundación del óvulo y la posterior formación del cigoto hasta que se constituye el organismo adulto. Los procesos ontogenéticos han sido objeto de estudio desde antiguo, en una búsqueda de los mecanismos subyacentes a los cambios que se producen durante el desarrollo.

Dentro del desarrollo de los vertebrados, las fases tempranas de la formación del Sistema Nervioso conllevan una serie de cambios en el organismo que influyen en gran medida en toda la morfogénesis posterior del animal. Además, el Sistema Nervioso es el centro rector de todo el individuo y donde radican las funciones superiores de cada especie. Es por ello que el desarrollo del Sistema Nervioso es uno de los procesos que han sido estudiados con mayor interés dentro del campo de la Embriología. Por otra parte, la variedad de tipos celulares que constituyen el Sistema Nervioso, la muy diferente naturaleza de los agentes utilizados en la modulación y transmisión de los impulsos nerviosos, y la compleja organización de los circuitos de transmisión, hacen arduo su análisis y difícil su comprensión. El análisis de organismos en fases de desarrollo temprano, cuyo Sistema Nervioso Central tiene una densidad celular considerablemente menor, nos permite seguir desde sus primeros momentos y con bastante precisión la evolución de las células y los procesos que acontecen en el tejido hasta llegar a constituir el modelo definitivo de organización en el adulto. 


\section{ONTOGENIA DEL SISTEMA NERVIOSO CENTRAL DE VERTEBRADOS}

El desarrollo del Sistema Nervioso es un proceso complejo que engloba fenómenos muy diversos que se suceden en el tiempo. Para facilitar su comprensión, el proceso en su conjunto puede dividirse en diferentes etapas. Así, en la formación inicial del Sistema Nervioso en los vertebrados podemos diferenciar cuatro fases principales:

a) Organización de campos o compartimentos clonales durante las etapas iniciales de segmentación del embrión. Un número restringido de blastómeros progenitores organizarán durante el desarrollo todos los derivados neurales (Hirose y Jacobson, 1979; Kimmel y cols., 1991).

b) Inducción neural del ectodermo en respuesta a señales de la notocorda subyacente (Spemann, 1938). Tras este proceso, las células ectodérmicas adquieren competencia neural, formándose la denominada placa neural, que es el primer esbozo embrionario del Sistema Nervioso Central. A cada lado de ella, unas bandas celulares se diferencian y constituyen las crestas neurales, estructuras precursoras del Sistema Nervioso Periférico.

c) Regionalización de la placa neural, en la que se establece un gradiente de inducción que determinará la organización anteroposterior y mediolateral del futuro Sistema Nervioso (Schmitz y cols., 1993).

d) Neurulación, proceso morfogenético que conduce a la formación del tubo neural al plegarse la placa neural a lo largo de su linea media (Schoenwolf y Smith, 1990).

El tubo neural queda constituido como un engrosamiento longitudinal en la superficie del embrión. Desde el momento de su formación, posee un diámetro desigual: el extremo anterior es más ancho, con las paredes más gruesas y la cavidad interior (neurocele) presenta un diámetro mayor que en el resto del tubo neural. Esta 
morfología prefigura el ulterior desarrollo del encéfalo a partir de la región anterior del tubo neural y la formación de la médula espinal desde las partes media y posterior.

Dentro del tubo neural recién constituido se van a producir una serie de fenómenos de histogénesis, que son los siguientes:

a) Proliferación celular. Tras su formación, la pared del tubo neural se constituye como un epitelio pseudoestratificado. En la capa ventricular, región limitante con el neurocele, se produce una división continuada de células neuroepiteliales cuya consecuencia inmediata es un aumento de la población celular y el engrosamiento del tubo neural (Altman, 1963). Poco después, en la región más externa del tubo neural va a aparecer una capa marginal constituida en un principio por las regiones apicales de las células neuroepiteliales, y que posteriormente se ensanchará por la llegada de prolongaciones que surgen de los cuerpos celulares de los precursores neuronales (Sauer, 1935).

b) Adhesión y comunicación celular. Establecimiento de uniones físicas entre células vecinas a través de las cuales permanecen conectadas entre sí. Son procesos especialmente importantes durante el desarrollo y están mediados por moléculas existentes en la superficie celular (Edelman, 1984; Lumsden y Keynes, 1989).

c) Diferenciación celular. Las células neuroepiteliales resultantes de divisiones sucesivas van a ir perdiendo su capacidad mitótica, y van diferenciándose como progenitoras de las diferentes estirpes celulares presentes en el Sistema Nervioso: neuroblastos y glioblastos; o bien retienen su carácter de células epiteliales, constituyendo el epitelio ependimario que recubre las cavidades ventriculares (Altman y Bayer, 1978, 1988).

d) Migración celular. Al inicio del proceso de diferenciación, las células se localizan en la región más interna de la pared del tubo neural (capa ventricular). En una primera oleada migratoria estas células se dirigen hacia la periferia, surgiendo 
una nueva capa en el tubo neural entre la ventricular y la marginal, que se denomina capa del manto, donde se sitúan las células en proceso de diferenciación. Posteriormente, a lo largo del desarrollo del tejido nervioso, se producen desplazamientos de poblaciones neuronales que se dirigen hacia el lugar que ocuparán en el encéfalo maduro formando las distintas regiones del Sistema Nervioso Central. Estos elementos neuronales son guiados por las prolongaciones de las células gliales radiales (Rakic, 1972), tipo especial de neuroglía con el cuerpo celular situado cerca de la luz ventricular y prolongaciones radiales dirigidas hacia la superficie del tubo neural.

e) Formación de conexiones específicas. La formación de sinapsis o sinaptogénesis es un proceso avanzado de la diferenciación neuronal, e implica la localización por parte de los axones de los lugares adecuados para realizar su arborización terminal sináptica. Para ello, el cono de crecimiento axónico se va desplazando a través del tejido, dirigido por fenómenos de quimiotaxis, hasta que alcanza la célula diana correcta (Sperry, 1963).

f) Estabilización de conexiones, con la consiguiente eliminación de las sinapsis anómalas, muerte de células que no lograron sinaptar (Sohal, 1976; Oppenheim, 1981; Cunningham, 1982) y reorganización de sinapsis, proceso este último que se da incluso durante la vida adulta del animal. Estos fenómenos se engloban bajo el concepto de plasticidad sináptica.

La inducción neural continúa actuando según un gradiente sobre el tubo neural, estableciéndose una serie de parcelaciones longitudinales que se denominan, de la porción más dorsal a la más ventral: placa superior o del techo, placa lateral alar, placa lateral basal (separadas una de otra por el sulcus limitans) y placa inferior o del suelo (Kuhlenbeck, 1973). Estas placas organizarán diferentes regiones y núcleos a lo largo del eje rostrocaudal del tubo neural. 
Los procesos microscópicos de histogénesis que se suceden en el tubo neural del nuevo organismo van acompañados por una serie de cambios morfológicos macroscópicos y una evolución hacia estructuras más complejas que darán lugar finalmente a la formación de las diferentes estructuras y núcleos que componen el Sistema Nervioso Central.

En cuanto se constituye como estructura independiente, el tubo neural se alarga y en su porción más rostral aparecen los primeros engrosamientos en su pared. Las diferentes regiones del tubo neural muestran un crecimiento independiente que las lleva a abombarse en lo que se conoce como segmentos neurales o neurómeros (Orr, 1887).

En un primer momento se originan las tres primeras vesículas cefálicas, que son el inicio de las tres grandes regiones encefálicas: prosencéfalo, mesencéfalo y rombencéfalo (Cowan, 1978, 1979). La etapa en la que el cerebro está formado por tres vesículas es breve. Rápidamente puede observarse la aparición de nuevos neurómeros. Al finalizar el desarrollo, el resultado de la segmentación ha producido la división de las tres vesículas primordiales en diferente número de neurómeros que se agrupan en las cinco grandes porciones en las que clásicamente se divide el encéfalo (Kuhlenbeck, 1973). El prosencéfalo embrionario se subdivide en telencéfalo, de localización anterior y diencéfalo, que ocupa la parte posterior del prosencéfalo. El mesencéfalo se sitúa tras el límite caudal del diencéfalo, y la tercera vesícula, el rombencéfalo, se diferencia a su vez en metencéfalo, situado en la parte anterodorsal, y mielencéfalo, en la parte ventral. La región del tubo neural caudal al mielencéfalo constituirá la médula espinal.

\section{MORFOGÉNESIS DEL SISTEMA NERVIOSO CENTRAL DE PECES TELEÓSTEOS}


Si bien el modelo general de desarrollo del Sistema Nervioso de teleósteos es común al del resto de los vertebrados, algunos de los procesos que acontecen durante el mismo se desarrollan según mecanismos peculiares y diferentes a los observados en otros vertebrados.

Ya en los momentos más tempranos del desarrollo pueden apreciarse diferencias. Así, el proceso de neurulación en los peces teleósteos difiere en algunos aspectos con el observado en otros grupos de vertebrados. Tras la inducción primaria, el ectodermo se engrosa y forma la placa neural. No aparecen, sin embargo, los característicos pliegues neurales, que al cerrarse formarán el tubo neural. En su lugar se forma una quilla neural central por mitosis sucesivas de las células de la placa neural. El canal central o neurocele se desarrolla secundariamente dentro del espesor del tejido, y no como resultado del curvamiento sobre sí misma de la primitiva placa neural (Hisaoka y Battle, 1958; Watermann y McCarty, 1977).

El proceso de proliferación a partir de células neuroepiteliales indiferenciadas se mantiene durante la vida adulta en algunas regiones del Sistema Nervioso Central de teleósteos. Aunque no se trata de una característica exclusiva de este grupo de animales, ha sido objeto de estudio en profundidad en regiones como la retina (Sharma y Romeskie, 1984), el techo óptico (Lara y cols., 1990), o el bulbo olfatorio (Alonso y cols., 1987).

Existen también diferencias en la morfogénesis tardía del encéfalo. Mientras que en la mayoría de los vertebrados el telencéfalo es producto de un proceso de inversión del tubo neural, en los peces teleósteos aparece tras un proceso de eversión (Gage, 1893, Nieuwenhuys y Meek, 1990). En primer lugar, surge una evaginación impar rostral, que va a reducirse tras la aparición de dos evaginaciones pares que originarán los dos hemisferios telencefálicos. A continuación, se produce el fenómeno de la eversión telencefálica, que provoca la aparición de un ventrículo central, limitado lateralmente por los dos hemisferios telencefálicos y dorsalmente por una lámina epitelial derivada de la placa del techo. El telencéfalo impar queda 
restringido a la región de la comisura anterior. Por último, surgen como dos evaginaciones rostrales los dos bulbos olfatorios, en los que el ventrículo se mantiene en los estadíos ontogenéticos tempranos, para obliterarse frecuentemente al final del desarrollo.

El Sistema Nervioso Central de teleósteos queda constituido como una estructura compleja, en la que pueden diferenciarse seis grandes regiones: telencéfalo, diencéfalo, mesencéfalo, metencéfalo, mielencéfalo y médula espinal, cuyas características describiremos a continuación.

\section{Telencéfalo}

Es la región que aparece tras la diferenciación de la porción más rostral del prosencéfalo embrionario. Es un derivado exclusivo de la placa alar y de la placa del techo (Kuhlenbeck, 1973).

El telencéfalo de los teleósteos está constituido por dos pares de estructuras, los bulbos olfatorios y los hemisferios telencefálicos. El bulbo olfatorio es el primer centro de relevo de la vía olfatoria. Como en todos los vertebrados muestra una estructura laminar (Nieuwenhuys, 1963) y contiene los cuerpos celulares de las células mitrales y de los granos, aunque hay también tipos neuronales y conexiones sinápticas no existentes en otros vertebrados (Alonso y cols., 1987, 1988; Arévalo y cols., 1991).

Los hemisferios telencefálicos están separados por el ventrículo central que aparece entre ambos durante el proceso de eversión. Histológicamente podemos distinguir dos regiones en el telencéfalo de teleósteos, que se conocen con los términos de área ventral y área dorsal, términos introducidos por Källen (1951). 


\section{Diencéfalo}

Se produce por diferenciación de la porción más caudal del prosencéfalo embrionario. En su formación tan solo intervienen elementos de la placa alar y de la placa del techo (Kuhlenbeck, 1973). Durante el desarrollo, la protovesícula diencefálica se subdividirá en tres vesículas: la más anterior dará lugar al hipotálamo y al tálamo ventral; la intermedia forma los territorios prospectivos del tálamo dorsal, el epitálamo y la glándula pineal; y por último la más caudal organizará la región del pretectum.

El diencéfalo de teleósteos es una región compleja situada entre el telencéfalo rostralmente y el mesencéfalo caudalmente. Los límites exactos no están claramente definidos y han sido objeto de numerosos estudios y discusión. Según Johnston (1911), el área preóptica se incluiría en el telencéfalo. Hoogenboom (1929) situó el límite rostral diencefálico en el centro del área preóptica y Herrick (1948) en posición rostral al área preóptica. Según Braford y Northcutt (1983), el área preóptica queda incluida dentro del diencéfalo, y el límite caudal de éste se sitúa entre las comisuras posterior y tectal dorsalmente, y entre el núcleo del fascículo longitudinal medial y el núcleo oculomotor, ventralmente.

His (1893) distingue tres zonas en el diencéfalo de teleósteos, que de dorsal a ventral son: epitálamo, tálamo e hipotálamo, reconocidas en todos los vertebrados. Posteriormente, otros autores han hecho otras divisiones del diencéfalo. Braford y Northcutt (1983) distinguen las siguientes regiones: área preóptica, pretectum, epitálamo, tres zonas talámicas (tubérculo posterior, tálamo ventral y tálamo dorsal), hipotálamo, y sinencéfalo, en el que se incluyen la comisura posterior y el núcleo del fascículo longitudinal medial.

\section{Mesencéfalo}


Esta región del tubo neural no se subdivide en otras entidades tras el proceso de morfogénesis temprana. Su pared está constituida por las placas basal, alar y del techo (Kuhlenbeck, 1973).

El mesencéfalo está formado por el techo mesencefálico o techo óptico y por el tegmentum. El techo óptico es el principal centro procesador de la información visual, así como el centro de integración de dicha información con la de otros sentidos y la locomoción. Está constituido por dos masas de forma cupuliforme que limitan el tercer ventrículo. Presenta una estratificación en varias capas concéntricas (Ariens-Kappers y cols., 1936; Lara y cols., 1983). Por su parte ventromedial, los dos hemitechos se unen a una protuberancia llamada torus longitudinalis, que interviene en la integración de los sentidos del equilibrio y de la visión (Ito y Kishida, 1978; Northmore y cols., 1983; Vanegas y cols., 1984).

El tegmentum se sitúa ventralmente al techo óptico y está limitado anteriormente por las raíces del nervio oculomotor y caudalmente por las raíces del nervio troclear, sin que sea visible ningún otro límite externo.

\section{Metencéfalo}

El metencéfalo está constituido por el cerebelo y estructuras asociadas. Deriva de la placa alar, y se organiza en los estadios tempranos en un cuerpo cerebelar primordial (placa cerebelar) y dos aurículas laterales (Kuhlenbeck, 1973).

El cerebelo de los teleósteos está dividido en tres grandes áreas: válvula del cerebelo, cuerpo del cerebelo y lóbulo vestibulolateral. Al igual que el cerebelo de otros vertebrados, la tres zonas están organizadas en tres capas: una capa molecular superficial, formada por las dendritas de las células de Purkinje y células gliales; una capa intermedia, la de las células de Purkinje; y una capa más profunda, la capa granular formada por pequeñas neuronas llamadas granos y los axones de las células 
de Purkinje (Finger, 1983). Sin embargo, hay también diferencias notables entre el cerebelo de teleósteos y el de otros vertebrados. Así, en teleósteos las células de Purkinje no son el elemento eferente del cerebelo, sino que proyectan a otro tipo neuronal, las células euridendroides, situadas entre las de Purkinje, y que son las que proyectan fuera del cerebelo (Finger, 1983).

\section{Mielencéfalo}

La parte principal del mielencéfalo es la médula oblongata que junto con el tegmentum mesencefálico forman el denominado tronco del encéfalo. La pared ventral de la médula oblongata es delgada y su pared dorsal está formada por un plexo coroideo que deriva de la placa del techo (Kuhlenbeck, 1973). Los nervios trigémino, abducens, facial, vestibuloacústico, glosofaríngeo y vago se originan y tienen sus núcleos en esta región cerebral. La región dorsal de la médula comprende el área sensorial, mientras que el área motora está en la región ventral. La región cercana al sulcus limitans forma el área visceral y la región más alejada el área somática (Nieuwenhuys y Pouwels, 1983). La médula oblongata de teleósteos contiene dos grandes células nerviosas, las células de Mauthner, que forman parte de la formación reticular y están encargadas de los movimientos rápidos de la musculatura corporal (Faber y Korn, 1978).

\section{Médula espinal}

La porción mas caudal al mielencéfalo constituye la médula espinal. En ella, las astas ventrales se derivan de la placa basal, mientras que las astas dorsales surgen de la alar, estando ambas zonas separadas entre sí por el sulcus limitans (Kuhlenbeck, 1973). La medula espinal de los teleósteos presenta una porción de sustancia gris central en forma de Y invertida. Por otro lado, existen tipos neuronales particulares 
(Nieuwenhuys, 1964) y conexiones sinápticas distintas de las existentes en otros vertebrados, como los contactos con las células de Mauthner (Celio y cols., 1979).

Como hemos visto, los procesos histogenéticos y morfogenéticos que se suceden durante la ontogenia del Sistema Nervioso han sido estudiados en profundidad. Ello no obstante, estamos aún lejos de poseer un conocimiento completo del desarrollo del Sistema Nervioso. Así, los mecanismos moleculares que controlan la especificación regional, la diferenciación y la morfogénesis no son bien conocidos. Por ello, el estudio de los patrones de expresión de diferentes sustancias neuroactivas a lo largo del desarrollo del Sistema Nervioso de teleósteos puede mostrar la existencia de divergencias hasta ahora desconocidas en la formación y en la constitución definitiva de sus centros nerviosos con respecto a lo observado en otros vertebrados. 


\section{EL CALCIO DURANTE EL DESARROLLO}

El ion calcio participa dentro del Sistema Nervioso en diversos procesos bioquímicos que suceden en las neuronas maduras. Dentro de ellas puede actuar como primer o segundo mensajero, y a la vez puede actuar como diana de diferentes sistemas de mensajeros secundarios (Rubin y cols., 1985). De entre todos los procesos en los que actúa pueden citarse la transducción de la señal nerviosa, la síntesis y liberación de neurotransmisores, la apertura de canales iónicos, y la activación de determinadas enzimas, como quinasas y proteasas (Evered y Whelan, 1986; Hidaka y cols., 1988).

Además de sus importantes funciones en el Sistema Nervioso adulto, muchos de los procesos que tienen lugar durante el desarrollo del Sistema Nervioso son calciodependientes; es decir, para que sucedan precisan de concentraciones particulares del ion calcio en el medio. Así, diversos estudios fisiológicos han demostrado que puede ser un factor clave en procesos críticos que tienen lugar durante el desarrollo temprano del Sistema Nervioso Central, como la elevación de la cresta neural y la neurulación (Anglister y cols., 1982; Mattson y cols, 1988). Además, los ciclos de división celular que se producen durante la etapa de proliferación celular se encuentran regulados, entre otros factores, por el ion calcio (Campbell, 1983; Hepler, 1994).

Con respecto a los procesos de adhesión y comunicación celular, una de las moléculas encargadas de la unión entre células vecinas es la cadherina. Esta molécula posee tres lugares de unión para calcio que han de ser ocupados por dicho ion para que la proteína sea funcional (Takeichi, 1990; Geiger y Ayalon, 1992). Igualmente el calcio interviene en los movimientos de migración celular (Campbell, 1983), en los procesos que desembocan en la elongación de las neuritas (Anglister y cols., 1982; Mattson y Kater, 1987; Mattson y cols., 1988) y en los movimientos de los conos de crecimiento en su búsqueda de las neuronas diana con las que establecerán sinapsis 
(Kennedy, 1989). Todos estos datos enfatizan la importancia del calcio en el control y modulación de los procesos ontogenéticos del Sistema Nervioso.

\section{PROTEÍNAS LIGANTES DE CALCIO}

Hasta el momento, nuestros conocimientos sobre los procesos que regulan la actuación del calcio durante el desarrollo y maduración del Sistema Nervioso Central son escasos. Una posible aproximación para la resolución de este problema puede ser el estudio de los patrones de expresión de una serie de proteínas intracelulares conocidas como proteínas ligantes de calcio, que al tamponar los niveles del ion dentro de la célula pueden promover o restringir sus funciones (Rogers, 1989b).

Las proteínas ligantes de calcio constituyen una familia de pequeñas proteínas ácidas, de bajo peso molecular, provistas de cavidades específicas que aceptan el ion calcio con gran afinidad y selectividad. Su constante de disociación es de rango milimolar (Persechini y cols., 1989; Van Brederode y cols., 1990). Esta alta afinidad es de gran importancia, pues los niveles de calcio intracelular son muy bajos (del orden micromolar). En el medio existen otros iones, como el potasio y el magnesio, en concentraciones semejantes (Hamoir, 1968; Berchtold, 1989), que no son retenidos por las proteínas ligantes de calcio.

Las proteínas ligantes de calcio se suelen dividir en dos grandes grupos:

- Anexinas: proteínas que además de calcio, son capaces de unir otras moléculas como los fosfolípidos.

- Proteínas del dominio EF (“EF-hand”): se denominan así por la morfología de los centros de unión al calcio (Khanna y cols., 1988; Persechini y cols., 1989). En este grupo se incluyen la calmodulina, S-100, troponina C, y las tres proteínas objeto de nuestro estudio, calbindina D-28k, parvalbúmina y calretinina. 
A su vez, según sea la respuesta que provocan tras su unión al calcio, las proteínas ligantes de calcio del dominio EF se pueden clasificar en disparadoras ("trigger") y tamponadoras ("buffer") (Khanna y cols., 1988; Celio, 1989). Las proteínas ligantes de calcio disparadoras cambian su conformación al unirse al calcio, lo que permite su posterior interacción con enzimas específicas o canales de membrana, modulando así su actividad. Este grupo incluye proteínas como la calmodulina, la calcineurina y la troponina C. En cambio, las tamponadoras no cambian su conformación y actúan como un sistema pasivo, encargado de ajustar las concentraciones intracelulares o locales de este ion. A este grupo pertenecen la parvalbúmina, la calbindina D-28k y la calretinina.

Todas las proteínas ligantes de calcio con la excepción de la troponina C (Roisen y cols., 1983; Anthony y cols., 1984) se han hallado en el cerebro de varias especies de vertebrados. Además, en todas las especies estudiadas, la parvalbúmina (Celio y Heizmann, 1981; Celio, 1986), la calbindina D-28k (Baimbridge y cols., 1982; Baimbridge y Miller, 1982; Feldman y Christakos, 1983; García-Segura y cols., 1984; Celio y cols., 1986) y la calretinina (Pasteels y cols., 1990; Résibois y Rogers, 1992) se expresan en subpoblaciones neuronales específicas.

Ello no obstante, parvalbúmina y calbindina D-28k han sido descritas en alguna ocasión como marcadores gliales. Así, Crespo y cols. (1995) describen la presencia de astrocitos marcados para ambas proteínas en cultivos mixtos de cerebro de rata. Se ha demostrado también la presencia de glía radial positiva para calbindina D-28k durante el desarrollo del telencéfalo del ratón (Liu y Graybiel, 1992).

Las principales características de las tres proteínas objeto de nuestro estudio son las que se detallan a continuación:

\section{Parvalbúmina}


La parvalbúmina fue aislada por primera vez en músculo esquelético de vertebrados anamniotas (carpa y rana) (Hamoir, 1968; Pechère y cols., 1977; Gerday, 1988; Gregersen y cols., 1990), y más tarde en músculo esquelético, riñón, testículo y cerebro de distintas especies de vertebrados (Heizmann, 1984; Heizmann y Berchtold, 1987). En animales anamniotas existen varias isoenzimas de parvalbúmina, a diferencia de lo que ocurre en animales amniotas en los que existe una única forma enzimática (Heizmann y Hunzinker, 1989; Heizmann y cols., 1990).

La parvalbúmina fue la primera proteína ligante de calcio de la que se conoció su estructura molecular (Kretsinger, 1980). Dicha estructura terciaria ha resultado ser similar para todas las proteínas ligantes de calcio de la familia EF, y está formada por seis regiones homólogas de hélice $\alpha$, con una región $\mathrm{N}$-terminal no helicoidal y cinco bucles $ß$ situados entre las hélices $\alpha$. Los lugares de unión al calcio están en los bucles que aparecen entre las hélices C-D y E-F, mientras que entre las hélices A-B la parvalbúmina no posee ningún lugar de unión para el ion. Su peso molecular es de 11.5 kDa (Schöffl y Jockusch, 1990).

Su función específica es aún desconocida. Se la ha relacionado con procesos de protección frente a diferentes desórdenes cerebrales; así, por ejemplo, en el hipocampo las células que contienen parvalbúmina son resistentes a isquemia (Tortosa y Ferrer, 1994). En distintas regiones cerebrales existe un amplio grado de colocalización entre parvalbúmina y el transmisor inhibidor ácido gammaaminobutírico, por lo que se ha postulado que la parvalbúmina podría estar involucrada en la alta velocidad de disparo que presentan las células inhibidoras (Celio, 1986). Además, la parvalbúmina puede unirse al calcio libre, facilitando el transporte del ion a otras partes de la neurona donde sea necesario (Glew y Coffee, 1984; Kuo y cols., 1986).

El inicio de su expresión se asocia en el tiempo con el inicio de la actividad fisiológica en poblaciones neuronales específicas (Solbach y Celio, 1991), cuando éstas ya están completamente diferenciadas (Berchtold y Means, 1985). 


\section{Calbindina D-28k}

La calbindina D-28k es una proteína con un peso molecular de $28 \mathrm{kDa}$ (Heizmann y cols., 1990) formada por seis dominios EF, de los cuales tan sólo cuatro aceptan calcio (Persechini y cols., 1989). Esta proteína requiere vitamina D para poder ser sintetizada por las células intestinales (Wasserman y Taylor, 1966; Taylor, 1974; Hunzinker y Schrickel, 1988); en cambio, en el Sistema Nervioso Central su biosíntesis es independiente de vitamina D (Varghese y cols., 1988).

La calbindina D-28k está ampliamente distribuida en el Sistema Nervioso Central (Baimbridge y Miller, 1982; Feldman y Christakos, 1983; García-Segura y cols., 1984; Celio y cols., 1986; Pinol y cols., 1990) y aparece, como regla general, en neuronas de sistemas amielínicos y de proyección difusa relacionados con subpoblaciones de interneuronas (Celio, 1989).

En relación con su papel fisiológico dentro del Sistema Nervioso, se ha postulado que la calbindina D-28k funciona como un tamponador intraneuronal de calcio, previniendo la acumulación excesiva de calcio libre citosólico, y protegiendo a las neuronas contra los procesos degenerativos de excitotoxicidad mediada por calcio (Iacopino y Christakos, 1990; Mattson y cols., 1991; Iacopino y cols., 1994). Así, se ha demostrado la supervivencia selectiva de neuronas que contienen calbindina D-28k en la sustancia nigra de enfermos afectados por la enfermedad de Parkinson y en modelos experimentales de dicha enfermedad (Yamada y cols., 1990; Lavoie y Parent, 1991; German y cols., 1992). Además de tamponar calcio para evitar la excitotoxicidad neuronal, la calbindina D-28k podría desempeñar un papel en el movimiento celular (Enderlin y cols., 1987) y en la regulación de los flujos intracelulares de calcio (Williams, 1992). El inicio de la expresión de calbindina D28k durante el desarrollo del Sistema Nervioso Central de mamíferos, coincide con 
los procesos que conducen a la diferenciación y a la sinaptogénesis (Enderlin y cols., 1987).

\section{Calretinina}

Es una proteína de 29-30 kDa (Rogers, 1987). La calretinina fue identificada clonando un cDNA de retina de pollo (Rogers, 1987). Este cDNA codifica para seis dominios EF, cuatro de los cuales son homólogos a los primeros dominios de la calbindina D-28k. La secuencia es homóloga en un 58\% a la de la calbindina D-28k en el pollo, y los segmentos más conservados entre la calretinina y la calbindina D28k son precisamente segmentos de la secuencia aminoacídica que no ligan calcio: los segmentos que continúan a los sitios II, IV y V, así como el sitio VI que tampoco liga calcio en la calbindina D-28k. Estos segmentos son también aquéllos que más se conservan entre la calbindina D-28k de aves (pollo) y mamíferos (rata).

La calretinina ha sido localizada inmunocitoquímicamente dentro del Sistema Nervioso Central principalmente en la retina y en neuronas pertenecientes a vías sensoriales (Pasteels y cols., 1990; Résibois y Rogers, 1992; Rogers y Résibois, 1992), existiendo un escaso grado de colocalización entre esta proteína y la

calbindina D-28k (Winsky y Jacobowitz, 1991; Miettinen y cols., 1992; Rogers y Résibois, 1992).

Al igual que la calbindina D-28k y la parvalbúmina, se ha postulado que la calretinina tiene un importante papel en la regulación de los niveles de calcio en el citoplasma y en su transporte intracelular, promoviendo o restringiendo las acciones del calcio dentro del metabolismo neuronal (Rogers, 1987). Sin embargo, la calretinina podría controlar de un modo más directo algunos procesos bioquímicos, como la fosforilación de proteínas de membrana (Yamaguchi y cols., 1991). 
La calretinina ha sido también propuesta como sistema de protección de las células. Así, en cultivos de corteza cerebral, las neuronas que contienen calretinina son resistentes a la excitotoxicidad provocada por la entrada masiva de calcio tras la apertura de ionóforos en su membrana (Lukas y Jones, 1994). Las neuronas corticales que expresan calretinina son también resistentes a condiciones de estrés nutritivo (Vogt-Weisenhorn y cols., 1996). 


\section{JUSTIFICACIÓN Y OBJETIVOS}

La citoarquitectura del Sistema Nervioso Central adulto de peces teleósteos ha sido objeto de estudio en diferentes especies: tenca, Tinca tinca (Arévalo y cols., 1992); carpín dorado, Carassius auratus (Peter y Gill, 1975); trucha arco iris, Oncorhynchus mykiss (Billard y Peter, 1982); pez cebra de aguas salobres, Fundulus heteroclitus (Peter y cols., 1975); el luchador siamés, Betta splendens (Marino-Neto y Sabbatini, 1988); el gimnoto, Apteronotus leptorhynchus (Maler y cols., 1991); el pez cíclido, Oreochromis mossambicus (Bäuerle y Rahmann, 1993); y el pez sapo, Opsanus tau (Highstein y cols., 1992), entre otros. Por otra parte, existen también datos sobre la citoarquitectura del Sistema Nervioso Central durante el desarrollo (Bäuerle y Rahmann, 1993; Toyoda y Uematsu, 1994), aunque generalmente restringidos a regiones concretas como el diencéfalo (Corujo y Anadón, 1990), el hipotálamo, (Naito y cols., 1993), la retina (Omura y Oguri, 1993), el techo óptico (Sharma, 1975; Raymond y Easter, 1983; Raymond y cols., 1983; Mansour-Robaey y Pinganaud, 1990), el cerebelo (Pouwels, 1978a,b,c,d), el tronco del encéfalo y la médula espinal (Leghissa, 1942) o el área octavolateral (Körtje y cols, 1991) de especies particulares.

Además de los estudios citoarquitectónicos utilizando técnicas morfológicas clásicas, se ha estudiado la distribución de diferentes sustancias neuroactivas en el Sistema Nervioso Central adulto de distintas especies de peces. Así, existen datos acerca de la localización de sustancia P (Sharma y cols., 1989; Vecino y cols., 1989; Alonso y cols., 1990; Vecino y Sharma, 1992; Weld y Maler, 1992), encefalinas (Reaves y Hayward, 1979; Vecino y cols., 1992), somatostatina (Sas y Maler, 1991; Zupanc y cols., 1991; Stroh y Zupanc, 1993), galanina (Holmqvist y Ekström, 1991; Yamamoto y cols., 1992; Power y cols., 1996), sintasa del óxido nítrico y NADPHdiaforasa (Schober y cols., 1993; Holmqvist y cols., 1994; Östholm y cols., 1994; Arévalo y cols., 1995a; Brüning y cols., 1995; Turner y Moroz, 1995; Villani y Guarnieri, 1995a,b; Anken y Rahmann, 1996; Jansen y Enger, 1996b; Pérez y cols., 
1996), colin acetiltransferasa (Ekström, 1987; Brantley y Bass, 1988; Zottoli y cols., 1988), ácido gamma-aminobutírico (Médina y cols., 1994; Roberts y cols., 1995), factor liberador de gonadotropina (Amano y cols., 1991; Bailhache y cols., 1994; Kudo y cols., 1994; Montero y cols., 1994; Parhar e Iwata, 1994; Kim y cols., 1995; Yamamoto y cols., 1995), oxitocina (Maejima y cols., 1994), aromatasa (Gelinas y Callard, 1993), vasotocina e isotocina (Van den Dungen y cols., 1982; Holmqvist y Ekström, 1991), serotonina (Van Veen y cols., 1984; Ekström y Ebbesson, 1989, Johnston y cols., 1990; Ekström, 1994), dopamina (Meek y cols., 1989; Roberts y cols., 1989; Ekström y cols., 1990; Holmqvist y Ekström, 1995), noradrenalina (Ekström y cols., 1986; Meek y cols., 1993), tirosina hidroxilasa (Hornby y cols., 1987; Alonso y cols., 1989a; Hornby y Piekut, 1990; Ekström y cols., 1992; Meek y Joosten, 1993; Ma, 1994), péptido intestinal vasoactivo (Alonso y cols., 1989b, 1990), neuropéptido Y (Vecino y Ekström, 1990; Pickavance y cols., 1992; Vallarino y cols., 1995), glutamato (Wang y Maler, 1994), factor liberador de tirotropina (Matz y Takahashi, 1994), e histamina (Ekström y cols., 1995).

Son mucho menos numerosos los estudios inmunocitoquímicos realizados en diferentes estadios del desarrollo de peces teleósteos: existen datos sobre la distribución de serotonina (Van Veen y cols., 1984; Ekström y cols., 1985; Bolliet y Ali, 1992), factor liberador de gonadotropina (Chiba y cols., 1994; Parhar y cols., 1995), sustancia P (Vecino y Sharma, 1992), somatostatina (Becerra y cols., 1995), ácido gamma-aminobutírico (Sandell y cols., 1994; Ekström y Ohlin, 1995), dopamina (Ekström y cols., 1992; Giorgi y cols., 1994) y tirosina hidroxilasa (Manso y cols., 1993; Becerra y cols., 1994a). Por tanto, nuevos estudios con diferentes marcadores inmunocitoquímicos pueden ofrecer nuevos datos acerca de los procesos, aún no bien conocidos, que transcurren durante la morfogénesis del Sistema Nervioso Central de teleósteos.

Existen estudios detallados sobre la distribución de calbindina D-28k, parvalbúmina y calretinina en el Sistema Nervioso Central de animales tetrápodos, 
tanto en adultos (Baimbridge y cols., 1982; García-Segura y cols., 1984; Celio, 1990; Arai y cols., 1991; Jacobowitz y Winsky, 1991; Rogers y Résibois, 1992; Andressen y cols., 1993; Kishimoto y cols., 1993; Martínez-Guijarro y cols., 1994; Ren y Ruda, 1994; Bastianelli y cols., 1995a,b) como durante la ontogenia (Enderlin y cols., 1987; Solbach y Celio, 1991; Alcántara y cols., 1993; Bastianelli y Pochet, 1993; Abbot y Jacobowitz, 1995). En cambio, son escasos los trabajos realizados en peces (Dechesne y cols., 1988; Denizot y cols., 1988; Losier y Matsubara, 1990; MiguelHidalgo y cols., 1991; Alonso y cols., 1992; Sanna y cols., 1993a; Briñón y cols., 1994; Arévalo y cols., 1995b; Djebar y cols., 1995) y éstos se limitan al estudio de la distribución de dichas proteínas en regiones determinadas del encéfalo de animales adultos. En nuestra revisión bibliográfica solo hemos encontrado un trabajo acerca de la distribución de estas proteínas a lo largo de la ontogenia del Sistema Nervioso de teleósteos, que describe la distribución de calbindina D-28k durante el desarrollo de la retina (Vecino y cols., 1993).

Las proteínas ligantes de calcio son marcadores inmunocitoquímicos tempranos en el desarrollo del Sistema Nervioso de los mamíferos (Enderlin y cols., 1987; Solbach y Celio, 1991) que permiten observar con detalle las características morfológicas de las células positivas. Por tanto, el estudio de la distribución de calbindina D-28k, parvalbúmina y calretinina puede ser de gran ayuda en la comprensión de los procesos que transcurren durante la diferenciación del Sistema Nervioso Central de peces teleósteos, así como aportar nuevos datos acerca de la estructura de los diferentes núcleos y regiones que lo componen.

Durante los últimos años, una de las líneas de investigación desarrolladas en la Unidad de Biología Celular del Departamento de Biología Celular y Patología ha sido el estudio de la localización de diferentes proteínas ligantes de calcio en el Sistema Nervioso Central de vertebrados anamniotas (Ibáñez, 1990; Weruaga, 1991; Briñón y cols., 1994; Arévalo y cols., 1995b) y amniotas (Alonso y cols., 1992, 1993, 1995; Briñón y cols., 1992). Por otra parte, desde hace más de una década se han realizado 
numerosos estudios concernientes a la citoarquitectura (Lara y cols., 1983, 1990, 1995; Alonso, 1987; Alonso y cols., 1987, 1988, Arévalo y cols., 1991, 1992; Briñón y cols., 1993; López, 1996) y quimioarquitectura (Alonso y cols., 1989a,b, 1990, 1992; Arévalo y cols., 1995a; Velasco y cols., 1995) del Sistema Nervioso Central de teleósteos adultos.

Combinando ambas líneas de investigación, abordamos en el presente trabajo el estudio de la distribución de tres proteínas ligantes de calcio, calbindina D-28k, parvalbúmina y calretinina en diferentes estadios del desarrollo del Sistema Nervioso Central de la trucha arco iris, Oncorhynchus mykiss (Walbaum, 1792) durante la prey posteclosión, con los siguientes objetivos:

1) Determinar el momento de inicio de la expresión de las tres proteínas ligantes de calcio en las principales divisiones y núcleos del Sistema Nervioso Central de dicho animal.

2) Analizar el patrón de evolución espacio-temporal de la expresión de dichas proteínas, a lo largo de la ontogenia del Sistema Nervioso Central.

3) Comparar nuestros resultados con los ya existentes sobre la distribución de proteínas ligantes de calcio durante la ontogenia del Sistema Nervioso Central de mamíferos, así como con los datos conocidos acerca de la distribución de otras sustancias neuroactivas durante el desarrollo del Sistema Nervioso Central de peces.

4) Aportar nuevos datos acerca de la formación y constitución citoarquitectónica de los diferentes núcleos que constituyen el Sistema Nervioso Central de la trucha arco iris, desde su aparición hasta su desarrollo final en el animal adulto. 
Material y Métodos - 1 -

\section{MATERIAL Y MÉTODOS}




\section{MATERIAL}

Para la realización de este trabajo hemos empleado como animal de experimentación la trucha arco iris, Oncorhynchus mykiss (Walbaum, 1792). Los ejemplares utilizados se obtuvieron en una piscifactoría gestionada por la Junta de Castilla y León, sita en el río Tormes a su paso por el término municipal de Galisancho (Salamanca).

La trucha arco iris es un animal ovíparo en el que la fecundación es externa. Al tratarse de un animal ectotermo o poiquilotermo, cuya temperatura corporal depende de las condiciones de temperatura del medio en el que vive, la tasa de desarrollo de la trucha arco iris aumenta linealmente con la temperatura tras superar un umbral bajo el cual el desarrollo no se produce y hasta llegar a un máximo en el que se detiene. Así, la duración del desarrollo es inversamente proporcional a la temperatura del agua en la que se depositaron los huevos fecundados. Por ello, para definir los estadios de desarrollo en las etapas de vida embrionaria no podemos referirnos a una escala de tiempo, sino que utilizamos una combinación de tiempo y temperatura denominada tiempo fisiológico, cuyas unidades son los grados-día ( ${ }^{\circ}$-día).

En nuestro estudio hemos considerado y analizado los siguientes estadios del desarrollo:

- Embrión: Desde la fecundación del huevo hasta la eclosión.

- Alevín: Desde la eclosión hasta que, tras la reabsorción del saco vitelino, adquieren una morfología corporal similar a la del adulto.

- Juvenil: Animales con la misma morfología corporal del adulto pero inmaduros sexualmente.

- Adulto: A partir de la madurez sexual. 
Los huevos fecundados obtenidos en la piscifactoría mediante fertilización artificial se trasladaron al laboratorio, donde fueron mantenidos en acuarios de $25 \mathrm{l}$ con agua no clorada en circulación continua y aireación forzada, dentro de una cámara isotérmica a temperatura constante de $5^{\circ} \mathrm{C}$, y en un ciclo de iluminación $12 \mathrm{~h}$ luz: 12 h oscuridad. En estas condiciones los huevos eclosionaron en un periodo que osciló entre los $370-410^{\circ}$-día, y la reabsorción completa del saco vitelino se produjo entre los 25 y 35 días después de la eclosión. Los alevines se alimentaron diariamente con pienso enriquecido (Tetra MikroMin).

Los individuos juveniles y adultos fueron obtenidos directamente de la piscifactoría, trasladados al laboratorio y mantenidos en acuarios con agua no clorada y aireación forzada a temperatura constante de $5^{\circ} \mathrm{C}$ hasta su procesado.

Los grupos de edad y número de ejemplares utilizados fueron los siguientes:

- Embriones de 50, 100, 150, 200, 250, 300, y 350-día: 13 ejemplares de cada grupo de edad.

- Alevines recién eclosionados, de 2, 6, 15, 21, y 30 días post-eclosión: 10 ejemplares de cada grupo de edad.

- Juveniles de 3 meses, juveniles de 6 meses, juveniles de 1 año, adultos de 3 años: 6 ejemplares de cada grupo de edad. 


\section{MÉTODOS}

\section{FIJACIÓN}

Todos los animales fueron anestesiados en metanosulfonato de tricaína (MS222, Sigma) al $0.03 \%$ en agua. Posteriormente, fueron fijados utilizando una mezcla de paraformaldehído al 4\% y ácido pícrico saturado al 15\% en tampón fosfato 0.1 M, pH 7.4.

El protocolo para la preparación de un litro de fijador fue el siguiente:

- Calentar $350 \mathrm{ml}$ de agua destilada hasta $85-90^{\circ} \mathrm{C}$ y disolver en ella $40 \mathrm{~g}$ de paraformaldehído. Si la solución no es transparente, añadir unas gotas de $\mathrm{NaOH} 0.1$ N.

- Enfriar la solución lo más rápidamente posible, con hielo alrededor del recipiente.

- Añadir 150 ml de ácido pícrico saturado (20 g de ácido pícrico en 500 ml de agua destilada, calentar hasta $50^{\circ} \mathrm{C}$ y dejar reposar).

- Filtrar la solución (es preferible filtrar los componentes por separado).

- Añadir $500 \mathrm{ml}$ de tampón fosfato $0.2 \mathrm{M}, \mathrm{pH}$ 7.4. Para corregir el pH añadir $\mathrm{NaOH}$ si se necesita alcalinizar o $\mathrm{NaH}_{2} \mathrm{PO}_{4}$ si se necesita acidificar.

Los embriones y alevines, por su pequeño tamaño, fueron fijados mediante inmersión en la mezcla fijadora durante tiempos que oscilaron de 1 a 10 horas dependiendo del tamaño del animal. Los ejemplares juveniles y adultos se perfundieron por vía intracardiaca, lavando en primer lugar el árbol vascular con una solución salina ( $\mathrm{NaCl}$ al $0.63 \%$ en agua destilada) con 5 U.I./ml de heparina para evitar la formación de coágulos. A continuación se introdujo el fijador por la misma vía en volumen variable en función del tamaño del animal (la cantidad utilizada varió 
entre 50 y $150 \mathrm{ml}$ ). Tras la perfusión se extrajo el cerebro y se postfijó en la misma solución fijadora durante 4-6 h.

\section{CORTE}

Los ejemplares de edades superiores a los $200^{\circ}$-día, tras finalizar el proceso de fijación, se lavaron en tampón fosfato $0.1 \mathrm{M} \mathrm{pH} 7.4$ y se crioprotegieron en una solución de sacarosa al 30\% previamente a su corte. En el caso de embriones, alevines y juveniles de hasta seis meses de edad se realizaron secciones de la cabeza completa, y sólo de los encéfalos en los ejemplares de más edad.

Tras su crioprotección, las piezas se congelaron rápidamente en nitrógeno líquido, evitando el contacto directo entre el nitrógeno y la muestra, y se cortaron en un criostato a una temperatura constante de $-25^{\circ} \mathrm{C}$. Se realizaron secciones coronales, sagitales y horizontales de 10 a $30 \mu \mathrm{m}$ de espesor, que fueron recogidas sobre portaobjetos doblemente gelatinizados. Las secciones se secaron a temperatura ambiente y fueron almacenadas a $-80^{\circ} \mathrm{C}$ hasta su procesado.

\section{PROCESAMIENTO DE EMBRIONES IN TOTO}

Debido a su escaso tamaño, los ejemplares de menor edad (embriones de 50 a 200-día) son atravesados fácilmente por la luz, por lo que fueron utilizados para la realización de preparaciones inmunocitoquímicas in toto. Para ello, estos ejemplares se lavaron en tampón fosfato $0.1 \mathrm{M}$ pH 7.4, y fueron mantenidos en una solución de glicerol al 30\% y polietilenglicol al 30\% en tampón fosfato $0.1 \mathrm{M}, \mathrm{pH} 7.4$ a $-80^{\circ} \mathrm{C}$ hasta su procesado. 


\section{TÉCNICA INMUNOCITOQUÍMICA EN SECCIONES DE TEJIDO}

Las secciones recogidas sobre portaobjetos se lavaron tres veces, a intervalos de 15 minutos, en tampón fosfato $0.1 \mathrm{M}, \mathrm{pH} 7.4$ a temperatura ambiente, para eliminar los restos de fijador, y se procesaron siguiendo la técnica inmunocitoquímica de la avidina-biotina-peroxidasa.

El protocolo que se siguió para llevar a cabo dicha técnica fue el siguiente:

1) Lavado de las secciones en metanol con un $10 \%$ de $\mathrm{H}_{2} \mathrm{O}_{2}$ durante 15 minutos para inhibir las peroxidasas endógenas.

2) Lavado de las secciones tres veces, a intervalos de 15 minutos, en tampón fosfato $0.1 \mathrm{M}, \mathrm{pH} 7.4$.

3) Incubación en el primer anticuerpo (anti-calbindina D-28k, antiparvalbúmina o anti-calretinina) durante tres días a $4^{\circ} \mathrm{C}$ en cámara húmeda. El anticuerpo se utilizó a una dilución de 1:1000 en el caso de anti-calbindina y antiparvalbúmina, y a una dilución de 1:20000 en el caso de anti-calretinina. En los tres casos el anticuerpo se disuelve en tampón fosfato 0.1 M (pH 7.4); a esta solución se añadió un $10 \%$ de suero fetal de ternera (Vector) para los anticuerpos anti-calbindina y anti-parvalbúmina, y un 5\% de suero normal de cabra (Vector) para el anticuerpo anti-calretinina. El medio de incubación contenía, además, un 0.05\% de Triton X-100 (Panreac) para favorecer la penetración de los anticuerpos.

4) Lavado en tampón fosfato 0.1 M, pH 7.4 tres veces, con un intervalo de 10 minutos entre cada lavado.

5) Incubación en el segundo anticuerpo. Se empleó inmunoglobulina G antiratón biotinilada de caballo (Vector) para anti-calbindina y anti-parvalbúmina, e inmunoglobulina G anti-conejo biotinilada de cabra (Vector) para anti-calretinina; en todos los casos a una concentración de 1:200 en tampón fosfato 0.1 M, pH 7.4, durante 90 minutos, a temperatura ambiente en cámara húmeda. 
6) Lavado de las secciones dos veces con un intervalo de 5 minutos entre uno y otro, en tampón fosfato 0.1 M, pH 7.4.

7) Incubación en el complejo avidina-peroxidasa (Vector) durante 2 horas a temperatura ambiente en cámara húmeda. El complejo se mantuvo durante 30 minutos a $4^{\circ} \mathrm{C}$ en oscuridad antes de su uso y se utilizó a una concentración de 1:225 en tampón fosfato 0.1 M, pH 7.4.

8) Lavado de las secciones dos veces. El primero de los lavados se realizó en tampón fosfato 0.1 M, pH 7.4 y el segundo en tampón Tris-HCl 0.1 M, pH 7.6.

9) El revelado de la peroxidasa se efectuó con una solución de 3,3’diaminobencidina (Sigma) al 0.05\% en tampón Tris-HCl 0.2 M, pH 7.6, con un $0.003 \%$ de $\mathrm{H}_{2} \mathrm{O}_{2}$.

La observación de las secciones al microscopio óptico permite decidir en que momento detener la reacción. Una vez alcanzado el grado de tinción deseado, se interrumpió rápidamente el revelado lavando las secciones con tampón fosfato $0.1 \mathrm{M}$, pH 7.4.

Tras el lavado, las secciones se deshidrataron en etanol en graduaciones crecientes $\left(70^{\circ}, 80^{\circ}, 90^{\circ}, 96^{\circ}\right.$ y $\left.100^{\circ}\right)$. A continuación, las secciones se aclararon en xilol y se montaron con Entellan (Merck) y cubreobjetos.

\section{TÉCNICA INMUNOCITOQUÍMICA IN TOTO}

Los embriones empleados se lavaron tres veces, a intervalos de 10 minutos, y otras tres veces a intervalos de 30 minutos en tampón fosfato $0.1 \mathrm{M}, \mathrm{pH} 7.4$. A continuación se procesaron siguiendo la técnica inmunocitoquímica de la avidinabiotina-peroxidasa. 
En el caso de las preparaciones in toto, el protocolo utilizado es similar al empleado para las secciones de tejido, con la diferencia de que los tiempos de incubación y lavado deben ser más largos, y es indispensable incluir en el tampón un detergente como el Triton X-100 para favorecer la penetración de los anticuerpos. El protocolo empleado es el siguiente:

1) Incubación en una solución formada por un 10\% de suero fetal de ternera y un $1 \%$ de albúmina de suero bovino en tampón fosfato $0.1 \mathrm{M}, \mathrm{pH}$ 7.4, durante 12 horas a temperatura ambiente y en agitación constante. En este y en todos los pasos posteriores se añadió un 1\% de Triton X-100 (Panreac) a los tampones de incubación y lavado.

2) Incubación en el primer anticuerpo (anti-calbindina D-28k, antiparvalbúmina o anti-calretinina) durante cuatro días a $4^{\circ} \mathrm{C}$ en agitación constante. El anticuerpo se utilizó en las mismas concentraciones que en el caso de las secciones de tejido.

3) Lavado en tampón fosfato $0.1 \mathrm{M}$, pH 7.4 tres veces durante 10 minutos cada una, y tres veces durante 30 minutos cada una.

4) Incubación en el segundo anticuerpo. Se emplearon las mismas inmunoglobulinas biotiniladas que para las secciones de tejido, en todos los casos a una concentración de 1:200, durante 12 horas, a $4^{\circ} \mathrm{C}$ en agitación constante.

5) Lavado en tampón fosfato $0.1 \mathrm{M}, \mathrm{pH} 7.4$ tres veces durante 10 minutos cada una, y tres veces durante 30 minutos cada una.

6) Incubación en el complejo avidina-peroxidasa (Vector) durante 16 horas a $4^{\mathrm{O}} \mathrm{C}$ en agitación constante. El complejo se mantuvo durante 30 minutos a $4^{\mathrm{O}} \mathrm{C}$ en oscuridad antes de su uso y se utilizó a una concentración de 1:225.

8) Lavado de las secciones tres veces. El primero de los lavados se realizó en tampón fosfato 0.1 M, pH 7.4, y los otros dos en tampón Tris-HCl 0.1 M, pH 7.6. 
9) El revelado de las secciones se efectuó con una solución de 3,3’diaminobencidina (DAB, Sigma) al 0.05\% en tampón Tris-HCl 0.2 M, pH 7.6, con un $0.003 \%$ de $\mathrm{H}_{2} \mathrm{O}_{2}$.

Una vez finalizada la reacción, se interrumpió rápidamente el revelado lavando las secciones con tampón fosfato $0.1 \mathrm{M}$, pH 7.4. Posteriormente, los embriones fueron montados entre dos cubreobjetos con un 30\% de glicerol en tampón fosfato 0.1 M, pH 7.4 .

\section{CONTROLES DE LA REACCIÓN INMUNOCITOQUÍMICA}

Para verificar la especificidad de la reacción se realizaron los siguientes controles inmunocitoquímicos:

1) Incubación del tejido en ausencia del primer anticuerpo. No se observó reacción.

2) Preabsorción del primer anticuerpo con el antígeno correspondiente en una cantidad de $100 \mu \mathrm{g} / \mathrm{ml}$. No apareció ningún tipo de marcaje.

3) Sustitución del segundo anticuerpo por una solución de tampón fosfato $0.1 \mathrm{M}, \mathrm{pH}$ 7.4. La reacción resultó negativa en todos los casos.

4) Tratamiento de las secciones exclusivamente con 3,3'diaminobencidina y agua oxigenada para comprobar la existencia o no de peroxidasas endógenas. No se observó reacción.

\section{ESPECIFICIDAD DE LOS ANTICUERPOS}

Los anticuerpos necesarios para la realización de la presente investigación fueron proporcionados por el profesor M. R. Celio, de la Universidad de Fribourg, Suiza. El proceso seguido para la obtención de dichos anticuerpos, así como las 
pruebas realizadas con el fin de asegurar su especificidad frente a la calbindina D-28k (Celio y cols., 1990), la parvalbúmina (Celio y cols., 1988) o la calretinina (Schwaller y cols., 1993), fueron los siguientes:

\section{Calbindina D-28k}

La calbindina D-28k utilizada como antígeno fue aislada de duodeno de pollo y clonada en ratones de la cepa BALB/c. Mediante un test de manchas se identificaron los clones productores de anticuerpo frente a calbindina D-28k. De los 3743 híbridos resultantes, sólo 25 produjeron anticuerpo contra esta proteína, siendo todos ellos estables durante meses.

Las pruebas realizadas para comprobar su especificidad fueron las siguientes: radioinmunoensayo, inmunohistoquímica e inmunoblot en electroforesis bidimensional en gel. Las reacciones cruzadas con otras proteínas ligantes de calcio han sido excluidas por radioinmunoensayo y por inmunoblot. La menor concentración de proteína detectable es de 10 ng de calbindina D-28k por prueba.

Dos de estos clones, el 300 y el 318, producían anticuerpo altamente reactivo para la determinación histoquímica de calbindina D-28k en todas las especies estudiadas, presentando reacciones cruzadas en tejidos de las siguientes especies: carpa, ratón, rata, conejo, mono y hombre.

Para la elaboración de este trabajo hemos utilizado el anticuerpo monoclonal McAB 300, que se une a su proteína correspondiente con una afinidad de 1.6 x 10-18 l/mol, según fue determinado por radioinmunoensayo. Una característica destacable de este anticuerpo es que no presenta en ningún caso reacción cruzada con anticuerpos frente a calretinina. 


\section{Parvalbúmina}

Para la obtención de anticuerpos contra parvalbúmina, la proteína fue aislada de músculo de carpa y clonada en la misma cepa de ratones utilizada para el caso de la calbindina D-28k. Los cultivos productores de dicho anticuerpo frente a parvalbúmina se seleccionaron, igual que se hizo con los clones productores de anticuerpo frente a calbindina D-28k, por medio de un test de manchas. En este caso, 30 de los 2600 híbridos totales producían anticuerpos contra parvalbúmina. Todos eran estables durante meses.

Con el fin de verificar la especificidad de los anticuerpos se emplearon las mismas pruebas que las efectuadas para la calbindina D-28k: radioinmunoensayo, inmunohistoquímica e inmunoblot en electroforesis bidimensional en SDS-gel. Mediante radioinmunoensayo y test de manchas se excluyeron reacciones cruzadas con otras proteínas ligantes de calcio. La menor concentración detectable de proteína coincide con la obtenida en el caso de la calbindina D-28k, 10 ng de parvalbúmina por ensayo. Los anticuerpos 235, 239 y 267 presentan reacciones cruzadas en las siguientes especies: carpa, ratón, rata, mono y hombre.

Entre estos, el anticuerpo monoclonal McAb 235, utilizado por nosotros, es el que posee un mayor índice de afinidad, 7.9 x 10-12 l/mol. Este anticuerpo reconoce un determinante común en carpa, rata, ratón, mono y hombre.

\section{Calretinina}

Para la obtención del anticuerpo contra calretinina se utilizó la proteína recombinante humana obtenida de lisados de Escherichia coli. Tras ser purificada, se inyectaron $20 \mu \mathrm{g}$ de proteína purificada en conejos para la producción de anticuerpos policlonales contra calretinina siguiendo el procedimiento descrito por Schwaller y cols. (1993). La especificidad del anticuerpo obtenido se comprobó mediante 
inmunoblot en SDS-gel de extractos proteicos obtenidos de homogenados de cerebro de mono, rata, pollo y pez; y mediante pruebas de inmunoabsorción en secciones de cerebro de mono y rata. Incubando con una mezcla de anticuerpos contra calbindina D-28k y calretinina en inmunoblots de las fracciones proteicas indicadas anteriormente se concluye que este anticuerpo no presenta reacciones cruzadas con calbindina D-28k en ninguna de las especies ensayadas.

\section{TINCIONES HISTOLÓGICAS BÁSICAS}

Con el fin de localizar las estructuras encefálicas en los distintos estadios de desarrollo, realizamos una tinción de Nissl, con la que se marcan de manera muy evidente los cuerpos celulares, y que por tanto permite una buena diferenciación de las distintas regiones del Sistema Nervioso. Para ello, un ejemplar de cada grupo de edad se cortó en criostato y las secciones se recogieron en portaobjetos gelatinizados. Estas secciones se mantuvieron durante diez días en una solución de formalina al 10\%, efectuándose cambios del fijador cada tres días. Posteriormente se lavaron las secciones en tampón fosfato 0.1 M, pH 7.4 y se dejaron secar. Una vez secas, se mantuvieron los cortes en una mezcla de cloroformo-etanol (1:1), durante una hora para eliminar los lípidos. Posteriormente se hidrataron las secciones en etanol en graduaciones decrecientes $\left(100^{\circ}, 70^{\circ}, 50^{\circ}\right)$ y finalmente en agua destilada. A continuación se sumergieron en una solución de tionina al 0.25\% en una mezcla de agua destilada (76.4\%), ácido acético 1 M (20\%) y NaOH 1 M (3.6\%), durante 15 segundos. Tras ello se lavaron sucesivas veces en agua destilada, se deshidrataron en etanol en graduaciones crecientes $\left(70^{\circ}, 80^{\circ}, 90^{\circ}, 96^{\circ}\right.$ con cinco gotas de acético glacial, $96^{\circ}$ y $100^{\circ}$ ). Finalmente, las secciones se aclararon en xilol y se montaron con Entellan (Merck) y cubreobjetos. 


\section{DOCUMENTACIÓN}

Los mapas del Sistema Nervioso Central se dibujaron mediante una cámara clara acoplada a un microscopio Zeiss; y los esquemas definitivos, indicando la distribución de los elementos positivos a cada una de las proteínas ligantes de calcio en las diferentes regiones, se realizaron con el programa informático CANVASTM 3.0.6. (Deneba Software), en un ordenador Macintosh Centris 660AV (Apple Computer Inc.).

Las fotografías se tomaron en fotomicroscopios Zeiss III y Axiophot (Zeiss) con películas T-Max y Technical Pan (Kodak). 
Resultados - 1 -

RESULTADOS 
Resultados - 2 -

A) DESCRIPCIÓN DE LOS RESULTADOS 


\section{DESCRIPCIÓN GENERAL DEL SISTEMA NERVIOSO CENTRAL DE LA TRUCHA ARCO IRIS}

\section{Telencéfalo}

El telencéfalo de la trucha arco iris está constituido por los bulbos olfatorios y los hemisferios telencefálicos. El bulbo olfatorio se desarrolla como una estructura laminar en la que podemos distinguir cuatro capas: capa de las fibras del nervio olfatorio, capa glomerular, capa plexiforme y capa de los granos. En los hemisferios telencefálicos de la trucha no se definen núcleos, pero podemos distinguir distintas áreas: dorsodorsal, dorsolateral, dorsomedial, ventrodorsal, ventrolateral, ventroventral y ventrosupracomisural.

\section{Diencéfalo}

El diencéfalo puede subdividirse en una serie de regiones que son: área preóptica, pretectum, epitálamo, tálamo, hipotálamo y sinencéfalo. Dentro del área preóptica aparecen una serie de núcleos de localización periventricular que son el núcleo preóptico periventricular, el núcleo preóptico y el núcleo anterior periventricular. En el pretectum se localizan el área pretectal, el núcleo geniculado lateral, el núcleo pretectal y el núcleo rotundo. El epitálamo está constituido por la habénula.

Dentro del tálamo podemos distinguir el tálamo dorsal, con los núcleos dorsolateral y dorsomedial, el tálamo ventral con los núcleos ventrolateral y ventromedial, y el tubérculo posterior, en el que aparecen el núcleo glomeruloso, el núcleo mamilar y el núcleo difuso del torus lateralis. 
Dentro del hipotálamo se localizan los núcleos anterior, lateral y posterior del túber, el núcleo posterior periventricular, el núcleo difuso del lóbulo inferior, y los núcleos del receso lateral y del receso posterior. Por último, el sinencéfalo de la trucha arco iris se encuentra constituido por el núcleo del fascículo longitudinal medial y la comisura posterior.

\section{Mesencéfalo}

Dentro del mesencéfalo podemos distinguir el techo óptico y el tegmentum mesencefálico. El techo óptico es una estructura laminar con seis estratos diferenciables, que del mas interno al más externo son: periventricular, blanco central, gris central, fibroso y gris superficial, óptico y marginal. Uniendo los dos hemitechos aparece el torus longitudinalis.

El tegmentum mesencefálico se sitúa ventralmente al techo óptico por debajo del ventrículo mesencefálico. En la región más lateral se sitúa el torus semicircularis, en la base del ventrículo mesencefálico. En las zonas mediales más rostrales se sitúan los núcleos de los nervios oculomotor y troclear, y más lateralmente el núcleo rojo. Más caudalmente se localiza el núcleo lateral de la válvula que hace intrusión hacia el ventrículo mesencefálico. En toda la extensión del tegmentum aparecen neuronas de gran tamaño que constituyen el núcleo reticular mesencefálico-tegmental. En las porciones más caudales, junto a la línea media del tegmentum, se dispone el núcleo interpeduncular.

\section{Metencéfalo}

El metencéfalo de los teleósteos está constituido por tres porciones: válvula del cerebelo, que se introduce rostralmente dentro del ventrículo mesencefálico, cuerpo del cerebelo y lóbulo vestibulolateral. En la porción lateral de éste último se diferencia 
la eminencia granular. En las tres regiones, el metencéfalo presenta una citoarquitectura laminar, pudiendo diferenciarse tres capas, cuya disposición de más externa a más interna en el cuerpo del cerebelo y el lóbulo vestibulolateral, y al contrario en la válvula del cerebelo, es: capa molecular, capa de las células de Purkinje y capa de los granos.

\section{Mielencéfalo}

Dentro del mielencéfalo se sitúan la mayoría de los núcleos de los pares craneales. Así, en esta región aparecen en progresión rostrocaudal el núcleo del nervio trigémino, el núcleo del nervio abducens, el núcleo del nervio facial, el núcleo del nervio octavo o vestibuloacústico, el núcleo del nervio glosofaríngeo, y el núcleo del nervio vago.

En el mielencéfalo se localizan también los núcleos del área octavolateral, que ocupan las porciones dorsolaterales y que de más rostral a más caudal son: núcleo intermedio del área octavolateral, núcleo vestibular magnocelular, núcleo tangencial y núcleo vestibular descendente. En íntima asociación con todos estos núcleos se sitúan las células de Mauthner, dos células de gran tamaño que se localizan junto al fascículo longitudinal medial, una a cada lado de la línea media. El fascículo longitudinal medial discurre por el mielencéfalo hacia la médula espinal.

En la zona ventromedial más rostral se diferencia el núcleo del rafe, y lateralmente a éste las diferentes porciones de la formación reticular, que de más rostral a más caudal son: núcleo reticular superior, núcleo reticular medio y núcleo reticular inferior. Por último, en las porciones más caudales del mielencéfalo aparece en posición dorsal el núcleo del fascículo solitario, y en la base ventral la oliva.

\section{Médula espinal}


Dentro de la médula espinal se diferencian las astas dorsales y ventrales, así como los corpúsculos epiteliales. Dentro de la médula aparecen además diferentes sistemas fibrilares ascendentes, descendentes y comisurales. 


\section{CALRETININA}

La calretinina es la proteína ligante de calcio de más temprana expresión durante el desarrollo del Sistema Nervioso de la trucha arco iris. Así, en el estadio de $150^{\circ}$-día tras la fecundación podemos observar células inmunorreactivas en la placoda olfatoria (fig. 34a), en el mielencéfalo (figs. 1d,e; 58a) y en la médula espinal (figs. 1f; 58a). La expresión de calretinina puede detectarse ya desde estadios preeclosión en el telencéfalo (figs. 2a; 35a; 36a), diencéfalo (figs. 1b,c; 37a,b; 40a; 42a; 45a) y mesencéfalo (figs. 2c-e; 46a), mientras que en el metencéfalo se observan elementos inmunorreactivos solamente a partir de la eclosión (figs. 3f-h; 51a).

En todos los estadios estudiados, el marcaje para calretinina dentro del Sistema Nervioso de la trucha arco iris se observó siempre en células de estirpe neuronal. En ningún caso podemos observar elementos gliales inmunoteñidos para calretinina.

\section{Telencéfalo}

Durante el desarrollo del telencéfalo, en su porción anteroventral se diferencian los bulbos olfatorios, región que recibe inervación del nervio olfatorio constituido por los axones de las células receptoras localizadas en el epitelio olfatorio. Los precursores de las células receptoras, situados en la placoda olfatoria, resultan inmunoteñidos para calretinina en el estadio de $150^{\circ}$-día (fig. 34a). A partir del estadio de 300-día, las células precursoras calretinina positivas finalizan su diferenciación a receptores (fig. 34b,d), enviando axones inmunoteñidos (fig. 34c) que pueden verse alcanzando el esbozo del bulbo olfatorio en su porción más ventral (figs. 2a; 3a; 35a). El número de axones inmunoteñidos para calretinina va aumentando durante el desarrollo embrionario y en los primeros estadios posteclosión. En los alevines de 6 días de edad, estos axones se arborizan dentro del bulbo olfatorio en campos terminales globosos o elipsoidales, los glomérulos olfatorios. Junto a este marcaje 
fibrilar, en el mismo estadio se observan células calretinina-positivas de morfología redondeada, sin prolongaciones marcadas, situadas junto a los glomérulos olfatorios.

El patrón de marcaje glomerular para calretinina se va haciendo más complejo a lo largo del desarrollo. En los alevines de 15 días (fig. 4a), 21 días y un mes aumenta progresivamente el número y tamaño de glomérulos marcados. Lo mismo ocurre con el número de células positivas, si bien éstas apenas aumentan su tamaño y no se observan prolongaciones marcadas saliendo de ellas.

En los juveniles de tres meses, las aferencias positivas para calretinina en el bulbo olfatorio se organizan en campos de glomérulos segregados topográficamente (fig. 35b). Pueden distinguirse siete campos: anterior medial, ventral medial, dorsal lateral, lateral, ventral posterior lateral, ventral posterior, y posterior lateral. En los juveniles de seis meses aparecen dos nuevos campos de glomérulos: dorsal posterior medial y dorsal posterior lateral. Las neuronas calretinina positivas se localizan en los límites entre la capa glomerular y la plexiforme (fig. 6a), no observándose la presencia de neuritas inmunopositivas.

En los juveniles de un año y en los adultos se mantiene el mismo patrón de marcaje fibrilar en la capa glomerular (figs. 9a; 35c,d). En estos estadios las células esféricas inmunopositivas para calretinina presentan, en ocasiones, una dendrita inmunorreactiva de escasa longitud (fig. 35e,f).

Caudalmente a los bulbos olfatorios se van desarrollando, mediante un proceso de eversión, los hemisferios telencefálicos. Los primeros elementos celulares inmunoteñidos para calretinina en los hemisferios telencefálicos, se observan en los embriones de $350^{\circ}$-día de edad. Se trata de células redondeadas localizadas en el área ventral y junto a la línea media de separación de los hemisferios (fig. 36a). En alevines recién eclosionados el número y tamaño de las células inmunopositivas va aumentando, y se localizan en las divisiones ventrodorsal, ventroventral y ventrosupracomisural del telencéfalo (figs. 3b,c; 36b). A los 6 días después de la 
eclosión aumenta el número de células inmunorreactivas en estas tres regiones (fig. 36c).

A partir de 15 días posteclosión, si bien la mayoría de las células inmunopositivas siguen localizándose en las áreas ventrodorsal y ventroventral junto al ventrículo telencefálico (fig. 4b,c), pueden observarse algunas células inmunopositivas a calretinina en el área ventrolateral, sobre todo en los niveles más caudales en los que aparece la comisura anterior.

En los juveniles de tres meses de edad, además del marcaje de somas neuronales, aparece marcaje para calretinina en un tracto fibrilar que, procedente de niveles diencefálicos, se divide en tractos de menor calibre. Dichos tractos finalmente se resuelven en campos terminales que ocupan el área dorsomedial telencefálica (fig. 36d). El mismo patrón de marcaje, con un ligero aumento en el número de células y fibras inmunoteñidas, se observa en los juveniles de seis meses de edad (fig. 6b-d).

La distribución de calretinina en los juveniles de un año de edad es similar al descrito hasta este momento, con la diferencia de que aumenta en gran medida el número de neuronas inmunorreactivas. Además la longitud de sus prolongaciones es mucho mayor (fig. 36e). Aumenta el número de neuronas positivas localizadas en el área ventrolateral. Los fascículos de fibras inmunorreactivas están más intensamente teñidos, y la región del área dorsomedial que inervan es mucho más amplia.

En los animales adultos el patrón fibrilar es idéntico al observado en los juveniles de un año. Sin embargo, el patrón de marcaje de somas neuronales es diferente. El número de neuronas positivas para calretinina localizadas en las regiones ventrales periventriculares es menor, y ha aumentado en gran medida en otras regiones, observándose somas inmunorreactivos en las porciones más externas de las áreas ventrolateral y dorsolateral telencefálicas (figs. 9b-d; 36f,g). La morfología de estas células es globular o piriforme, y presentan prolongaciones inmunoteñidas. 


\section{Diencéfalo}

Podemos observar marcaje para calretinina en todas las grandes divisiones en las que se parcela el diencéfalo: área preóptica, pretectum, epitálamo, tálamo, hipotálamo y tubérculo posterior, así como en el sinencéfalo.

Dentro del diencéfalo, los primeros elementos inmunorreactivos para calretinina que detectamos son observados en el estadio de $200^{\circ}$-día, en los esbozos del tálamo (figs. 1c; 40a) y del área preóptica (figs. 1b; 37a,b). Se trata de células redondeadas, débilmente teñidas y que no presentan prolongaciones marcadas. En el siguiente estadio estudiado, $250^{\circ}$-día, además de las células anteriormente descritas en el área preóptica y en el tálamo, observamos células inmunoteñidas de similares características en las regiones del hipotálamo caudal presuntivo (fig. 42a).

En el estadio de $300^{\circ}$-día aparecen neuronas intensamente teñidas en el núcleo preóptico periventricular del área preóptica (fig. 2b) y en el esbozo de la región pretectal que limita con el techo óptico mesencefálico (fig. 2c,d). Además, el patrón general de marcaje se va complicando. Dentro del tálamo, ya podemos identificar dos grupos de neuronas localizadas a diferentes alturas, correspondientes las más dorsales al tálamo dorsal y las más ventrales al tálamo ventral (fig. 2c,d). Dentro del hipotálamo, observamos neuronas inmunorreactivas para calretinina en el núcleo del receso lateral, en el núcleo difuso del lóbulo inferior (figs. 2e; 42b) y en los núcleo anterior y lateral del túber (fig. 2c,d). En el tubérculo posterior aparecen las primeras neuronas inmunorreactivas en la región más rostral (fig. 2e). La morfología de las células marcadas en este estadio es generalmente redondeada, si bien algunas presentan una morfología ovalada con cortas prolongaciones.

A partir de los $350^{\circ}$-día las células del núcleo del fascículo longitudinal medial son positivas para calretinina (fig. 3e). Son células de morfología redondeada u ovoide, y con un tamaño ligeramente mayor que las de los núcleos adyacentes y cortas prolongaciones marcadas. 
En el siguiente estadio, el de la eclosión, el marcaje se complica, y puede observarse un mayor número de grupos de células inmunorreactivas. Así, dentro del área preóptica pueden diferenciarse neuronas esféricas con cortas prolongaciones inmunorreactivas localizadas en el núcleo preóptico periventricular (fig. 37c), en el núcleo preóptico y en el núcleo anterior periventricular (figs. 3d; 37d). En el pretectum aparece inmunorreactividad para calretinina en el esbozo del núcleo geniculado lateral y del núcleo rotundo (fig. 3d,e). En ambos casos las células positivas están débilmente teñidas, y se agrupan en masas circulares muy apelotonadas.

Dentro del tálamo dorsal se observan células inmunorreactivas de morfología fusiforme, monopolares, situadas junto al suelo del ventrículo, y con dendritas orientadas en dirección ventrolateral. En el tálamo ventral se observa un grupo de células inmunorreactivas con características similares, si bien la orientación de los somas y sus neuritas es perpendicular al eje dorsoventral del diencéfalo (figs. 3e; 40b).

También la estructura del hipotálamo se hace más compleja, y van apareciendo una serie de núcleos en sucesión rostrocaudal en los que observamos células inmunoteñidas para calretinina. Resultan inmunopositivas algunas células redondeadas indiferenciadas en el núcleo posterior periventricular (fig. 3e), y más ventralmente en los núcleos anterior y lateral del túber (figs. 3d,e; 43a). Más caudalmente dentro del hipotálamo aparecen células con una mayor intensidad de tinción y que presentan cortas prolongaciones marcadas, orientadas en dirección perpendicular a los recesos ventriculares hipotalámicos. Este tipo de células lo observamos en el núcleo posterior del túber (fig. 43b), en los núcleos del receso lateral y del receso posterior (figs. 3e; 42c), así como en el núcleo difuso del lóbulo inferior (fig. 3f). En la región del tubérculo posterior se observan células esféricas en los esbozos del núcleo difuso del torus lateralis y del núcleo glomeruloso (fig. 3e).

Al llegar al estadio de 15 días tras la eclosión el patrón de marcaje en el diencéfalo alcanza su máximo grado de complejidad. Además de los núcleos 
anteriormente indicados del túber (fig. 43c,d) y tubérculo posterior (fig. 44a,b), que presentan un grado mayor de desarrollo, distinguimos por primera vez dentro del pretectum dos nuevos grupos celulares inmunorreactivos, pertenecientes al núcleo pretectal y al área pretectal (figs. 4e; 38a). Además se observan por primera vez células inmunoteñidas, esféricas y sin prolongaciones en el complejo habenular del epitálamo (figs. 4d; 39a). Dentro del tálamo observamos cuatro grupos individualizados de células calretinina positivas situadas en los núcleos dorsomedial, dorsolateral, ventromedial y ventrolateral del tálamo (figs. 4e,f; 40c,d). Estas neuronas talámicas tienen morfología piriforme y presentan cortas prolongaciones marcadas. Además, podemos distinguir algunas células esféricas, sin prolongaciones marcadas, en el núcleo mamilar del tubérculo posterior. En el núcleo del fascículo longitudinal medial del sinencéfalo las neuronas inmunorreactivas son elípticas y de mayor talla que las de regiones adyacentes, y sobre ellas pueden observarse en ocasiones terminales positivos para calretinina (figs. 4f; 49c).

En las etapas siguientes, las células inmunorreactivas para calretinina en el diencéfalo van diferenciándose progresivamente a lo largo de los estadios juveniles (figs. 6e-g; 7; 9d-f; 10; 11) adquiriendo el patrón de inmunotinción que reflejamos a continuación.

Dentro del área preóptica, todas las células positivas son ovoides, monopolares y con sus prolongaciones dispuestas perpendicularmente a la pared ventricular. El grupo más numeroso se localiza en la región del núcleo preóptico periventricular (figs. 6d; 9d), siendo las células del núcleo preóptico las que presentan dendritas inmunoteñidas de mayor longitud (fig. 37f,h). Las células presentes en el núcleo anterior periventricular son de un tamaño ligeramente menor que las de los otros dos núcleos (fig. 37e,g).

En el pretectum, el marcaje de cuerpos celulares perfila y divide en dos lóbulos al núcleo geniculado lateral, cuyo interior se encuentra inervado por un fino plexo de fibras positivas a calretinina (figs. 6e,f; 9e; 38b-d). En niveles más caudales del 
diencéfalo observamos inmunorreactividad en células grandes, de morfología variada, poligonales o fusiformes, con cortas prolongaciones marcadas, pertenecientes al núcleo pretectal (figs. 6f,g; 9f; 10a; 38b,c,f). En el mismo nivel en que aparece el núcleo pretectal observamos marcaje en células redondeadas monopolares y fusiformes bipolares situadas junto a la pared del ventrículo mesencefálico, correspondientes al área pretectal (figs. 6g; 9f; 38e). A este mismo nivel podemos observar un moderado marcaje en células redondeadas y terminales difusos dentro del núcleo rotundo (figs. 6g; 7a,b; 9f; 10; 11a; 41a,d).

El tálamo de la trucha arco iris presenta un marcaje muy extenso (figs. 6g; 7a; 9f; 10a,b). En la región dorsal, observamos células inmunorreactivas para calretinina en los núcleos dorsomedial y dorsolateral (fig. 41a-c), más cercano este último al área pretectal. Se trata de células fusiformes monopolares que dirigen sus prolongaciones hacia el núcleo rotundo del pretectum. En el tálamo ventral, gran número de neuronas inmunorreactivas se localizan en los núcleos ventrolateral y ventromedial (fig. 41d). Estas células están intensamente teñidas, son algo mayores que las observadas en el tálamo dorsal y se organizan en racimos desde el centro de la región talámica hasta los límites del pretectum, rostralmente y del tubérculo posterior, caudalmente.

También se observa marcaje para calretinina en toda la extensión rostrocaudal del hipotálamo (figs. 6g; 7; 9f; 10; 11). En sus regiones más rostrales aparecen células inmunorreactivas de morfología alargada y monopolares junto a la comisura horizontal, correspondientes a los núcleos anterior y lateral del túber (fig. 43e). Algo más caudalmente, aparecen neuronas piriformes con su eje mayor y sus dendritas orientadas perpendicularmente al eje dorsoventral del encéfalo en la región del núcleo posterior periventricular. En los niveles en los que aparecen los recesos ventriculares hipotalámicos, aparecen células inmunoteñidas para calretinina en los núcleos que los rodean, tanto en el núcleo posterior del túber (fig. 43f) como en los de los recesos posterior y lateral (fig. 42d-f). Estas células inmunorreactivas se sitúan junto a la pared de los recesos ventriculares, y presentan una única prolongación dirigida en 
dirección opuesta a éstos. Por último, aparecen células de morfologías diversas, monopolares o bipolares, dispersas por el núcleo difuso del lóbulo inferior (fig. 44e).

En el tubérculo posterior, se observa inmunotinción para calretinina en el núcleo glomeruloso y en el núcleo difuso del torus lateralis (figs. 7a,b 9f; 10; 11a). En el núcleo glomeruloso vemos neuronas globulares débilmente teñidas, rodeadas por un fino entramado de fibras positivas (fig. 44c,d). En las regiones más laterales del tubérculo posterior se sitúa el núcleo difuso del torus lateralis. Este núcleo presenta, sobre todo en las regiones de contacto con el tálamo, algunas células dispersas inmunoteñidas. Se trata de células de tamaño medio, con morfologías muy variadas (redondeadas, poligonales, irregulares) y varias prolongaciones marcadas (fig. 44c,e). Por último, en la porción más caudal se sitúa el núcleo mamilar (figs. 7b; 11a), en el que se observan gran cantidad de células esféricas, moderadamente teñidas, sin prolongaciones marcadas (fig. 44f).

El marcaje en el sinencéfalo aparece en las células del núcleo del fascículo longitudinal medial (fig. 10c). Se trata de neuronas grandes, ovoides o elipsoidales, con una prolongación inmunorreactiva, situadas junto al ventrículo. Además, podemos observar campos terminales calretinina positivos en esta región, tanto sobre células inmunorreactivas como sobre células negativas (fig. 49c,d).

La habénula epitalámica se localiza en la porción más dorsal del diencéfalo. El marcaje, que en esta región aparece a los 15 días después de la eclosión (figs. 4d; 39a), no sigue el patrón general de aumento gradual observado en otras regiones diencefálicas. Desde que aparece hasta el estadio de tres meses, aumenta el número de elementos marcados y su intensidad de tinción (fig. 39b,c). A partir del estadio de seis meses (fig. 6e) la intensidad de tinción y el número de elementos marcados disminuye, desapareciendo la inmunorreactividad para calretinina en la habénula del adulto (figs. 9e; 39d). 
La retina es un derivado neural que se origina a partir de la vesícula óptica diencefálica. Los primeros elementos inmunorreactivos para calretinina se observan dentro de la retina en el estadio de $250^{\circ}$-día. Se trata de células situadas en la región central de la retina, localizadas por encima de la capa plexiforme interna presuntiva (fig. 45a). Son células de morfología redondeada con una prolongación marcada en dirección vitreal.

En el estadio de $300^{\circ}$-día, además de un mayor número de elementos inmunorreactivos localizados por encima de la capa plexiforme interna, aparecen algunas células ganglionares débilmente teñidas en la región central de la retina. En el estadio de eclosión aumenta el número de células ganglionares inmunorreactivas así como la intensidad de tinción que presentan. Las células localizadas por encima de la capa plexiforme interna son más abundantes y están más intensamente teñidas, extendiéndose el marcaje a zonas algo más alejadas de la porción central retiniana en relación a lo observado en el estadio anterior. Tienen soma piriforme y un proceso inmunorreactivo único que se dirige hacia la capa plexiforme interna. Estas características morfológicas, así como su localización nos permiten identificarlas como células amacrinas. Además aparece un denso marcaje neuropilar en la capa plexiforme interna debido a las prolongaciones de las células amacrinas inmunorreactivas, que se arborizan en dicha capa (fig. 45b).

En los estadios posteriores de alevín (fig. 45c) se produce una complicación en el patrón de marcaje, que además se va distribuyendo desde el centro de la retina hacia regiones cada vez más periféricas. Además de las células ganglionares y de las amacrinas, aparecen células bipolares inmunorreactivas con su soma localizado en la capa nuclear interna.

En los juveniles de tres y seis meses, el patrón apenas muestra diferencias con el descrito para los alevines. Numerosas células ganglionares resultan débilmente marcadas para calretinina. Además observamos inmunorreactividad en células bipolares localizadas en el seno de la capa nuclear interna, justo por debajo de la capa 
plexiforme externa, así como en células amacrinas con prolongaciones dirigidas hacia la capa plexiforme interna, donde estas prolongaciones se arborizan en un denso plexo de prolongaciones inmunorreactivas para calretinina (fig. 45d).

\section{Mesencéfalo}

Tras los procesos de morfogénesis cerebral, el mesencéfalo embrionario dará lugar a dos regiones diferenciadas en el encéfalo de la trucha arco iris: el techo óptico y el tegmentum mesencefálico.

El techo óptico recibe, entre otras, aferencias retinianas a través del nervio óptico que está constituido por los axones de las células ganglionares de la retina. Estas neuronas, como hemos descrito anteriormente, presentan inmunorreactividad para calretinina en el estadio de $300^{\circ}$-día (fig. 45b). En el mismo estadio de desarrollo observamos células positivas en el límite del techo óptico con la región del pretectum del diencéfalo (figs. 2c-e; 46a). Desde el estadio de eclosión, axones débilmente teñidos para calretinina pueden observarse en el nervio y tracto óptico (fig. 46e). Además aumenta el número de células positivas para calretinina en la región germinal. En la zona blanca externa aparecen algunas fibras positivas para calretinina en la zona ventral, junto con algunas células esféricas de pequeño tamaño (figs. 3d-g; 46b). Los animales de 6 días de edad presentan un patrón de marcaje similar.

A los 15 días, el techo óptico de la trucha ha complicado su laminación. A partir de la zona blanca externa se desarrolla un estrato óptico, en el que podemos observar la presencia de fibras inmunorreactivas para calretinina, y un estrato marginal que carece de ellas (figs. 4d,g; 46c). Las fibras marcadas se localizan en el tercio más anterior de la extensión rostrocaudal del techo óptico (fig. 4d,f). En este estadio las células inmunorreactivas son muy abundantes en el estrato periventricular (figs. 4d-g; 5a,b; 46c). 
Gradualmente la laminación del techo óptico va haciéndose cada vez más compleja. Al llegar al estadio de tres meses después de la eclosión aparece, ventralmente al estrato óptico, el estrato fibroso y gris superficial. Estos dos estratos presentan inervación de fibras calretinina positivas en un patrón bilaminar característico en la mitad anterior de la extensión rostrocaudal del techo óptico (fig. 46d). El estrato periventricular disminuye su tamaño relativo respecto al total del espesor del techo óptico, y se originan dos nuevos estratos, el gris central y el blanco central. En éste último se observan haces de fibras inmunorreactivas a calretinina discurriendo longitudinalmente (fig. 46d). El número y tamaño de las células inmunorreactivas en los demás estratos ha aumentado, presentando todas morfologías ovoides, globulares o fusiformes, y no se observan en ellas prolongaciones marcadas.

En los juveniles de seis meses de edad, las células inmunorreactivas para calretinina en el techo óptico muestran variaciones en su morfología. Mientras las células del estrato periventricular siguen presentando formas globulares sin prolongaciones, características de células indiferenciadas, en los otros estratos su forma es ahusada o redondeada, orientadas tanto en dirección paralela como perpendicular a la laminación tectal (fig. 46f). En ocasiones pueden verse cortas prolongaciones inmunoteñidas. El patrón de aferencias calretinina positivas en los estratos fibroso y gris superficial y óptico es más nítido que en estadios anteriores, y ocupa los dos tercios anteriores de la extensión rostrocaudal del techo óptico (figs. 6eg; 7a,b).

En los juveniles de un año de edad (fig. 47a), la laminación del techo óptico es la misma que en el adulto (fig. 47b). El patrón de aferencias en los estratos retinocipientes (estrato óptico, estrato fibroso y gris superficial, y estrato blanco central) ocupa toda la extensión rostrocaudal del techo óptico (figs. 9e,f; 10; 11; 12a). Las células positivas para calretinina del estrato periventricular de los juveniles de un año de edad aún no presentan prolongaciones marcadas. Por el contrario, las situadas en otros estratos están más diferenciadas. Podemos observar células fusiformes y 
piriformes con una o dos prolongaciones cortas inmunoteñidas en todos los estratos excepto en el marginal. En este último aparecen células esféricas inmunoteñidas de pequeño tamaño, con una corta prolongación que se dirige hacia el estrato óptico (fig. 47c).

El patrón de marcaje en los adultos presenta variaciones con respecto al descrito para los juveniles. Así, las células del estrato periventricular presentan una dendrita apical inmunoteñida (fig. 47e,f), que cruzando el espesor del techo se arboriza en el estrato fibroso y gris superficial y en el estrato óptico. Por otro lado, en los adultos no aparecen células marcadas en el estrato marginal, aunque sí observamos pequeñas células con cortas prolongaciones en la zona más superficial del estrato óptico (fig. 47d). Las aferencias positivas para calretinina muestran un patrón bilaminar homogéneo en toda la extensión dorsoventral del techo óptico, mientras que las aferencias al estrato blanco central se sitúan predominantemente en la región dorsal del techo óptico.

Uniendo los dos hemitechos, a los 15 días tras la eclosión, se empieza a desarrollar el torus longitudinalis (fig. 4e-g). En este estadio y en todos los siguientes hasta el estado adulto se observan dentro de él pequeñas neuronas inmunorreactivas con prolongaciones paralelas al eje rostrocaudal de la estructura.

La otra región que constituye el mesencéfalo de la trucha arco iris es el tegmentum mesencefálico. No observamos marcaje en neuronas de ninguno de los pares craneales que se sitúan en esta región, el núcleo del nervio oculomotor y el núcleo del nervio troclear en ninguno de los estadios analizados. Los primeros elementos inmunorreactivos para calretinina detectados en el tegmentum aparecieron a los $300^{\circ}$-día. Se trata de células indiferenciadas situadas en los territorios presuntivos del torus semicircularis y del núcleo reticular mesencefálico-tegmental (fig. 2e). 
En el estadio de eclosión se observan los esbozos de la mayoría de las estructuras tegmentales que resultaron ser positivas para calretinina durante el desarrollo. Así, aparece marcaje en el torus semicircularis (figs. 3e; 50b), núcleo lateral de la válvula (figs. 3f; 50a), núcleo interpeduncular (figs. 3f; 48a), y núcleo reticular mesencefálico-tegmental (figs. 3f; 50b). A los 15 días tras la eclosión podemos distinguir algunas células esféricas positivas rodeadas de terminales marcados para calretinina en el núcleo rojo (figs. 4g; 49c). Todas las estructuras tegmentales mencionadas anteriormente van aumentando su volumen hasta alcanzar el patrón adulto (figs. 7; 10; 11), que describiremos a continuación.

Las dos porciones del tegmentum más próximas al ventrículo son el torus semicircularis, situado más lateralmente, y el núcleo lateral de la válvula, medial a la región anterior. En el torus semicircularis (figs. 7; 10b,c; 11) observamos la presencia junto al ventrículo mesencefálico de células esféricas o fusiformes, pequeñas y monopolares, con sus prolongaciones dirigidas ventralmente (fig. 50f), así como otras de morfología ovoide situadas entre fascículos negativos a calretinina (fig. 50g). En el núcleo lateral de la válvula (figs. 7c; 11b,c), aparecen gran cantidad de neuronas inmunorreactivas para calretinina. Se trata de células esféricas y de pequeño tamaño y en las que no pueden observarse prolongaciones inmunopositivas (fig. 50e). La morfología y distribución de estas neuronas se mantiene constante a lo largo del desarrollo, observándose tan sólo un gradual aumento en su tamaño hasta alcanzar el estado adulto.

Más ventralmente se sitúa el núcleo reticular mesencefálico-tegmental y el núcleo rojo. En el núcleo reticular mesencefálico-tegmental, en los estadios de alevín, observamos células esféricas o piriformes positivas a calretinina (fig. 50c), que van aumentando en estos estadios progresivamente su tamaño y número, así como la longitud de sus prolongaciones. En los estadios juveniles (fig. 7c) y en el adulto (fig. 11b,c), el núcleo está formado por neuronas grandes, ovoides o poligonales distribuidas por una amplia región del núcleo (fig. 50d). En el núcleo rojo (figs. 7a,b; 
11a) observamos la llegada de terminales calretinina positivos que realizan contactos tanto con células positivas como con otras negativas para calretinina (fig. 49c,d).

En la región más ventral del tegmentum y junto a la línea media se localiza el núcleo interpeduncular, dividido en dos porciones, una ventral y otra dorsal. En ambas porciones se observan a partir del estadio de eclosión células inmunorreactivas para calretinina, esféricas y pequeñas, así como terminales inmunopositivos (fig. 48a). En este núcleo el patrón de evolución temporal de la inmunorreactividad para calretinina es diferente. En los estadios de alevín el número de células marcadas va aumentando progresivamente (figs. 3f; 5b; 48b,c), pero al llegar al desarrollo juvenil se produce un descenso progresivo en el número de células y fibras marcadas, que se sitúan en la región periférica del núcleo interpeduncular en los animales de uno, tres y seis meses (figs. 7c; 48d). En el estadio de un año las células positivas a calretinina son muy pocas y se localizan en los límites externos del núcleo interpeduncular (fig. 48e). Por último, no se observa inmunorreactividad ni en cuerpos celulares ni en fibras en el núcleo interpeduncular del adulto (figs. 11c; 48f).

\section{Metencéfalo}

La placa cerebelar metencefálica no presenta ningún marcaje para calretinina durante los estadios embrionarios. El primer estadio en el que se observan elementos inmunorreactivos para calretinina es el de eclosión (fig. 3f-h). Así, observamos la presencia de un tracto de fibras positivas a calretinina que, penetrando por la región ventrolateral, se dirige hacia las zonas mas dorsales. Además, se observa un grupo de células marcadas con una intensidad de tinción moderada, globulares y de tamaño muy pequeño (fig. 51a).

En el siguiente estadio estudiado, 2 días después de la eclosión, el tracto fibrilar es de mayor calibre, con mayor número de fibras inmunorreactivas a calretinina. El grupo celular positivo sigue presentando las mismas características morfológicas y de 
inmunotinción. En los alevines de 6 días, las células inmunorreactivas para calretinina son algo mayores, y algunas de ellas presentan cortas prolongaciones marcadas (fig. 51b). Estas células son identificadas como granos. En los animales de 15 días el marcaje en los granos se hace más extenso, y aparecen tanto en el lóbulo vestibulolateral como en la válvula del cerebelo y las porciones más rostrales del cuerpo del cerebelo (fig. 5a-c).

En los alevines de un mes, además del marcaje fibrilar en la zona superficial y de los granos, observamos otras células inmunorreactivas a calretinina en el lóbulo vestibulolateral y en el cuerpo del cerebelo. Se trata de células piriformes, con una menor intensidad de tinción que los granos, situadas en un estrato monocelular, y presentan una gruesa dendrita dispuesta paralelamente a la laminación cerebelar. Estas características nos permiten identificarlas como células de Lugaro.

En los juveniles de tres meses el marcaje para calretinina es muy extenso, apareciendo en todas las regiones metencefálicas excepto en la eminencia granular. Así, pueden observarse fibras positivas a calretinina a nivel de la capa de células de Purkinje en la válvula y el cuerpo del cerebelo, y granos intensamente teñidos en las dos regiones, así como en el lóbulo vestibulolateral. Por último se observan células de Lugaro moderadamente inmunorreactivas en el lóbulo vestibulolateral, y en posición ventral y dorsal en los niveles más rostrales del cuerpo del cerebelo y en la válvula del cerebelo (fig. 51c).

Este patrón se mantiene en todos los demás estadios hasta llegar al adulto (figs. 11; 12a-d; 51d,e), aunque el número y tamaño de los elementos inmunorreactivos va aumentando con la edad. Además, en los animales de mayor edad (juveniles de un año y adultos), observamos algunas neuronas inmunorreactivas a calretinina, monopolares y esféricas dispersas en la eminencia granular (fig. 51d). En la capa de células de Purkinje, donde llegan las aferencias positivas a calretinina, podemos observar la presencia de botones terminales sobre los cuerpos de las células de Purkinje, que 
resultan negativas para calretinina en todos los estadios de desarrollo estudiados (fig. 51f).

\section{Mielencéfalo}

El mielencéfalo es una de las regiones en las que la expresión de calretinina es más temprana durante el desarrollo. En el estadio de $150^{\circ}$-día se observan células inmunoteñidas para calretinina, situadas en la zona más ventral del mielencéfalo. Las células presentan morfología piriforme y una corta dendrita dirigida ventralmente (fig. 58a). Las identificamos como precursores de neuronas reticulares. En secciones horizontales de embriones de $250^{\circ}$-día podemos observar como estas neuronas reticulares mielencefálicas envían sus prolongaciones caudalmente reunidas en un tracto que discurre paralelo a la línea media del encéfalo (fig. 54a).

En el estadio de $300^{\circ}$-día puede observarse como las células inmunorreactivas para calretinina se localizan en los esbozos de diferentes núcleos mielencefálicos (fig. 2f-i). Así, observamos células positivas a calretinina en el núcleo vestibular magnocelular, núcleo tangencial, núcleo intermedio del área octavolateral y núcleo vestibular descendente, todos ellos pertenecientes al área octavolateral, y en los núcleos reticulares superior, medio e inferior. En el núcleo vestibular magnocelular (fig. 2g) aparecen células inmunorreactivas de gran tamaño con prolongaciones que se dirigen medialmente. El núcleo tangencial, situado entre el anterior y la salida del nervio vestibuloacústico (fig. 2g), contiene células esféricas de menor tamaño con prolongaciones que toman la misma dirección que las anteriores. El núcleo intermedio del área octavolateral está situado más dorsalmente que los anteriores, a lo largo de la mayoría de la extensión rostrocaudal del mielencéfalo (fig. 2f-h). En él se observan pequeñas neuronas inmunoteñidas sin prolongaciones inmunorreactivas a calretinina. Células con las mismas características de inmunotinción aparecen en el núcleo 
vestibular descendente, que aparece caudalmente a los anteriores (fig. 2h). A lo largo del mielencéfalo podemos observar en este estadio la presencia de neuronas esféricas o piriformes muy intensamente teñidas localizadas en las regiones centrales del mielencéfalo, que constituyen, de más rostral a más caudal, los núcleos reticulares superior (fig. 2f), medio (fig. 2g,h) e inferior (fig. 2i). Además, a nivel del esbozo del núcleo del fascículo solitario se observan pequeñas células inmunorreactivas esféricas o elipsoidales (fig. 56a).

En el estadio de eclosión, además de en los núcleos anteriormente citados (fig. 3g-j) observamos neuronas inmunorreactivas en la oliva, el núcleo gustatorio secundario y el núcleo del rafe (fig. 3f-j). Las neuronas de la oliva son esféricas y se encuentran inmersas en un fino entramado de fibras positivas a calretinina (fig. 56b). El núcleo gustatorio secundario puede distinguirse junto al límite ventral del metencéfalo, adyacente al cuarto ventrículo, y en él aparecen pequeñas células esféricas y fibras inmunorreactivas (fig. 52b). En la zona ventral, a ambos lados de la línea media mielencefálica, podemos diferenciar las neuronas del núcleo del rafe de las de los núcleos reticulares por su menor tamaño y su patrón de ramificación específico hacia la línea media del mielencéfalo (fig. 54b).

En los animales de 6 días de edad observamos neuronas inmunorreactivas a calretinina en diferentes núcleos de los pares craneales. Podemos distinguirlas tanto por su localización específica como por su morfología, diferente a la de las neuronas reticulares circundantes que presentan forma más irregular.

A partir de los 6 días tras la eclosión no aparece ningún nuevo grupo de células inmunorreactivas para calretinina en el mielencéfalo, observándose únicamente un incremento en el número y tamaño de las células en los subsiguientes estadios de alevines y juveniles hasta llegar al estado adulto (figs. 5b-e; 8a-d; 12a-e). A continuación describiremos el patrón de inmunomarcaje para calretinina que pudo observarse a lo largo de dichos estadios y en el adulto. 
Dentro del mielencéfalo se disponen varios núcleos de los nervios craneales. Siguiendo el eje rostrocaudal, el primero en aparecer es el núcleo del nervio trigémino (figs. 5c; 8a; 12 a; 52a,c,e). En él podemos observar células intensamente teñidas para calretinina, de morfología fusiforme, que se sitúan en posición dorsomedial junto al cuarto ventrículo y presentan prolongaciones que se dirigen ventrolateralmente.

Más caudalmente, y en posición ventrolateral con respecto al anterior, se situaban las neuronas inmunopositivas para calretinina del núcleo del nervio abducens (figs. 5d; 8b; 12b; 53a-c). Son neuronas más pequeñas que las del resto de los núcleos de los nervios craneales, de morfología globular con una prolongación que se dirige ventrolateralmente.

Los dos núcleos de los pares craneales más caudales que aparecen marcados para calretinina son el núcleo del nervio facial y el núcleo del nervio vestibuloacústico (figs. 5d; 8c; 12c; 53a,b,d). Ambos aparecen al mismo nivel mielencefálico, si bien el núcleo del nervio facial se sitúa dorsocentralmente y el núcleo del nervio vestibuloacústico más ventrolateralmente. La morfología de las células en ambos núcleos es similar, células alargadas o piriformes con prolongaciones que se dirigen ventrolateralmente (fig. 53d). Las células de los núcleos de los nervios glosofaríngeo y vago no resultan positivas para calretinina en ninguno de los estadios estudiados.

Dentro del sistema de núcleos vestibulares y del área octavolateral aparecen neuronas inmunorreactivas para calretinina ampliamente distribuidas por los diferentes núcleos que lo componen. El primer núcleo de este sistema en aparecer a lo largo del eje rostrocaudal del mielencéfalo es el núcleo intermedio del área octavolateral (figs. 5c-e; 8b,c; 12a-c). Observamos neuronas inmunopositivas pequeñas, esféricas, en algunos casos con cortas prolongaciones, a lo largo de toda la extensión rostrocaudal del núcleo (fig. 55a,d).

Ventralmente al núcleo intermedio del área octavolateral se sitúan el núcleo vestibular magnocelular y el núcleo tangencial (figs. 5c; 8b; 12b). En ambos aparece 
inmunomarcaje para calretinina (fig. 55b,e). En el núcleo vestibular magnocelular aparecen células de gran tamaño, débilmente inmunoteñidas, globosas o elípticas, con una o dos prolongaciones, alrededor de las cuales pueden observarse fibras terminales arrosariadas también positivas para calretinina. En el núcleo tangencial, las neuronas son de menor tamaño, más intensamente teñidas, con una o dos cortas prolongaciones. Las células de los núcleos del área octavolateral envían prolongaciones hacia la línea media del encéfalo, las cuales en algunas ocasiones se decusan y contactan con los cuerpos celulares negativos de las células de Mauthner. En otros casos, las prolongaciones se integran en el fascículo longitudinal medial (fig. 49a,b), en cuyo interior podemos observar numerosas fibras inmunopositivas a lo largo de toda su extensión, que alcanzan los núcleos de los nervios oculomotor y troclear (fig. 49e,f), así como el núcleo rojo y el núcleo del fascículo longitudinal medial (fig. 49c,d). Además de estas proyecciones contralaterales, las células de los núcleos del área octavolateral, originan fibras inmunorreactivas que se integran en el tracto vestibuloespinal ipsilateral, dirigiéndose a las regiones más caudales del encéfalo y la médula espinal.

Más caudalmente se observa marcaje en el núcleo vestibular descendente (figs. 5d; 8c; 12c; 55c,f). Se trata de pequeñas neuronas esféricas fuertemente inmunorreactivas, con cortas prolongaciones marcadas. Alrededor de este núcleo aparece un intenso marcaje en las fibras nerviosas que constituyen la rama descendente del tracto vestibuloespinal.

Junto a la porción ventral de la línea media del mielencéfalo observamos inmunorreactividad para calretinina en neuronas pertenecientes al complejo del rafe (figs. 5c,d; 8a,b; 12a,b; 54c,d). Son células de pequeño tamaño, muy intensamente teñidas. Presentan una prolongación fuertemente marcada dirigida hacia la línea media del mielencéfalo, donde las prolongaciones de estas neuronas forman un denso plexo inmunorreactivo (fig. 54d). 
Dentro de la formación reticular aparece marcaje en toda la extensión rostrocaudal del mielencéfalo. Rostralmente se observan células calretinina positivas moderadamente teñidas localizadas a nivel del núcleo reticular superior (figs. 5c; 8a; 12a), con morfologías variadas desde fusiformes a poligonales, con dos o tres prolongaciones dendríticas marcadas. Más caudalmente se observa inmunotinción a nivel del núcleo reticular medio (figs. 5d; 8b; 12b,c) en dos subpoblaciones de neuronas reticulares. Una de ellas la constituyen células fusiformes intensamente teñidas, con una o dos prolongaciones marcadas sin orientación definida (figs. 53b,c; 54e). La otra subpoblación reticular media está constituida por neuronas más débilmente marcadas que las anteriores, de mucho mayor tamaño y localizadas cerca de la línea media mielencefálica (figs. 53b,d; 54c,f). Por último, a nivel del núcleo reticular inferior (figs. 5e; 8c; 12d) observamos dos subpoblaciones neuronales de características morfológicas similares a las descritas en el núcleo reticular medio.

Junto a la pared del cuarto ventrículo, podemos observar marcaje en el núcleo gustatorio secundario (figs. 5b; 8a; 12a). En él se observan células inmunorreactivas de soma esférico alineadas en dos o tres hileras junto a la pared del cuarto ventrículo. Presentan prolongaciones marcadas que se dirigen lateralmente hasta llegar a un denso plexo de fibras inmunopositivas (fig. 52d,f).

En las porciones más caudales del mielencéfalo se observa inmunorreactividad para calretinina en el núcleo del fascículo solitario y en la oliva (figs. 5d,e; 8c,d; 12ce). Dentro del núcleo del fascículo solitario aparecen pequeñas células inmunorreactivas, de morfología esférica, dispuestas en hilera y con una única prolongación que se dirige ventralmente (fig. 56c,e). Dentro de la oliva, situada en la porción más ventral de los niveles caudales mielencefálicos, podemos observar un denso entramado de terminales inmunorreactivos entre los que se disponen pequeñas neuronas esféricas monopolares o bipolares (fig. 56d,f).

Adyacente a la parte externa de las paredes mielencefálicas se desarrolla el ganglio vestibuloacústico perteneciente al Sistema Nervioso Periférico. Dentro de este 
ganglio podemos observar neuronas inmunorreactivas para calretinina a partir del estadio de $350^{\circ}$-día. Se trata de células grandes, globosas o fusiformes, que en este estadio muestran una intensidad de tinción moderada (fig. 57a). En los estadios siguientes pueden observarse prolongaciones marcadas surgiendo de polos opuestos del soma, que son cada vez de mayor longitud. En el estadio de 2 días de edad se observa como una de ellas penetra en el mielencéfalo en la región del núcleo vestibular magnocelular y del núcleo tangencial, mientras que la otra se dirige por la rama eferente del ganglio vestibular para inervar las células receptoras vestibulares. En los alevines de 15 días (fig. 5c), en los estadios juveniles (figs. 8b; 57b) y en los adultos (fig. 12b) va aumentando progresivamente el número de neuronas inmunorreactivas localizadas en el ganglio vestibuloacústico. Dichas neuronas envían gran cantidad de prolongaciones inmunoteñidas hacia el mielencéfalo, que toman dos direcciones diferentes. Algunas se decusan en la línea media contactando con la célula de Mauthner contralateral (fig. 57c,d), mientras que otras se dirigen hacia los núcleos vestibulares del área octavolateral ipsilateral, en los que observamos campos terminales inmunorreactivos tanto sobre células positivas como negativas para calretinina.

\section{Médula espinal}

La médula espinal junto con el mielencéfalo son las regiones del Sistema Nervioso Central en las que primero aparece el marcaje para calretinina. En los embriones de $150^{\circ}$-día procesados in toto para calretinina podemos observar una serie de células piriformes situadas en una hilera rostrocaudal en la porción ventral de la médula espinal, con una corta prolongación dirigida hacia las regiones dorsales de la médula (fig. 58a).

El número de neuronas positivas a calretinina va aumentando a lo largo del desarrollo embrionario (figs. 1f; 2j). Al llegar al estadio de 350-día, en secciones transversales de la médula espinal, podemos observar numerosas neuronas inmunoteñidas a diferentes alturas dentro del espesor de la médula, todas redondeadas 
o piriformes (fig. 58b). A los 2 días de edad, estas neuronas se distribuyen por las astas dorsales y ventrales, y presentan prolongaciones marcadas (fig. 58c).

En los estadios sucesivos las neuronas positivas a calretinina van aumentando en número y tamaño (figs. 3k; 5f). En el estadio de 15 días pueden identificarse dos subpoblaciones neuronales de características diferentes (fig. 58d). Una formada por motoneuronas, de morfología poligonal y tamaño grande, y otra subpoblación formada por interneuronas medulares de morfología ovoide o fusiforme y de menor tamaño. También aparece marcaje fibrilar en los fascículos de la sustancia blanca, y un fino entramado de campos terminales alrededor de las neuronas inmunonegativas.

En los estadios juveniles de tres y seis meses (fig. 8e) se distinguen con mayor claridad las dos subpoblaciones de neuronas medulares positivas a calretinina. Las interneuronas medulares tienen formas elípticas o redondeadas, con cortas prolongaciones, mientras que las motoneuronas son mucho mayores y de morfología poligonal. En estas últimas podemos observar la presencia de prolongaciones inmunoteñidas extendiéndose por el asta dorsal, y una prolongación de mayor longitud que discurre por el asta ventral hasta salir por la raíz ventral medular (fig. 58e).

En los juveniles de un año se alcanza el patrón definitivo, que se mantiene en los adultos (fig. 12f). Pueden observarse neuronas inmunopositivas esféricas, de pequeño tamaño y cortas prolongaciones a nivel de los corpúsculos epiteliales medulares (fig. 58h). Podemos observar además interneuronas semilunares y redondeadas (fig. 58f), así como motoneuronas de gran tamaño (fig. 58g). Además, aparece marcaje en fibras de las comisuras medulares, así como en los tractos descendentes, y en un fino entramado de terminales calretinina positivos situados alrededor de neuronas inmunonegativas localizadas en las astas ventrales de la médula (fig. 58f). 


\section{PARVALBÚMINA}

Dentro de las proteínas ligantes de calcio estudiadas, la parvalbúmina es la más tardía en su aparición durante la ontogenia del Sistema Nervioso de la trucha arco iris. Las primeras células positivas se observan en derivados de la cresta neural anexos al mielencéfalo (territorios presuntivos del ganglio asociado al nervio vestibuloacústico) a la edad de $250^{\circ}$-día preeclosión (fig. 67a). Por el contrario, las primeras células inmunorreactivas en el Sistema Nervioso Central se observan a la edad de 6 días tras la eclosión en el núcleo vestibular magnocelular y en el núcleo tangencial del área octavolateral (fig. 66a), así como en el cerebelo (fig. 63a). En el resto de las regiones encefálicas la aparición de marcaje para parvalbúmina es más tardía, produciéndose cuando la morfogénesis encefálica está muy avanzada.

Además del marcaje en elementos neuronales, aparece inmunotinción para parvalbúmina en células gliales. Dicho marcaje está localizado en las zonas limitantes con los ventrículos encefálicos (fig. 59c,e), en el canal del epéndimo y en asociación con algunos tractos nerviosos (fig. 68e,f) en los juveniles de un año y en los adultos.

\section{Telencéfalo}

Los primeros elementos marcados para parvalbúmina en el telencéfalo de la trucha arco iris aparecen en el estadio juvenil de seis meses. Se trata de pequeñas neuronas esféricas, débilmente teñidas y sin prolongaciones marcadas situadas en las divisiones dorsolateral y dorsodorsal de los hemisferios telencefálicos (figs. 15; 59b).

En las truchas juveniles de un año el marcaje en el telencéfalo es más extenso. Se observan elementos débilmente inmunoteñidos para parvalbúmina en el bulbo olfatorio, pertenecientes a dos subpoblaciones neuronales diferentes. Una constituida por neuronas grandes, piramidales o piriformes, con una o dos cortas prolongaciones marcadas, localizadas en el límite entre los estratos glomerular y plexiforme. La otra 
está constituida por células grano de morfología esférica, localizadas en el seno del estrato granular (fig. 59a).

El marcaje en los hemisferios telencefálicos es más abundante en los ejemplares de un año de edad, aumentando tanto en número como en intensidad de tinción. Además de las áreas dorsodorsal y dorsolateral, presentan marcaje para parvalbúmina las áreas ventrodorsal, ventroventral, ventrosupracomisural y dorsomedial, donde aparecen neuronas esféricas inmunoteñidas, sin prolongaciones marcadas.

La comisura anterior presenta un marcaje difuso para parvalbúmina, aunque sin que puedan diferenciarse fibras individuales. En los mismos niveles en los que aparece la comisura anterior pueden apreciarse fascículos teñidos de manera similar a la comisura, que se dirigen hacia las áreas dorsodorsal y dorsolateral, en las que puede observarse un tenue marcaje de campos terminales.

En el telencéfalo de los animales adultos (fig. 18a-d) se mantiene el mismo patrón de marcaje que en las truchas juveniles de un año, observándose un ligero aumento en el número y en el tamaño de las neuronas inmunorreactivas. Así, observamos tanto las dos subpoblaciones positivas para parvalbúmina localizadas en el bulbo olfatorio, como las neuronas esféricas débilmente teñidas en las áreas dorsolateral, dorsomedial, dorsodorsal, ventrodorsal, ventroventral y ventrosupracomisural de los hemisferios telencefálicos. Asimismo, se observa en las truchas adultas el mismo marcaje fibrilar difuso en la comisura anterior y en los tractos que aparecen al mismo nivel (fig. 59c,d).

Además del marcaje neuronal, en los animales juveniles de un año de edad y en los adultos, observamos elementos gliales positivos a parvalbúmina situados en el telencéfalo de la trucha. Estas células tienen su soma localizado en la región limitante periventricular, o en regiones dorsales de la limitante subpial. Presentan un cuerpo celular alargado y una prolongación positiva que se dirige hacia el interior de los 
hemisferios telencefálicos. Por su morfología y localización las hemos identificado como ependimocitos (fig. 59e).

\section{Diencéfalo}

Dentro del diencéfalo, las primeras neuronas positivas a parvalbúmina aparecen en los animales de 15 días de edad en el sinencéfalo, y las identificamos como pertenecientes al núcleo del fascículo longitudinal medial (fig. 13). Se trata de células grandes, globosas u ovoides, que se disponen medialmente junto a la pared del ventrículo mesencefálico (fig. 60a). A lo largo del desarrollo del animal estas células van aumentando su tamaño, hasta que en los individuos de 6 meses pueden observarse como células de gran tamaño que envían prolongaciones inmunoteñidas hacia las regiones más caudales del encéfalo y la médula espinal a través del fascículo longitudinal medial (figs. 16; 60c). Células con las mismas características pueden observarse en las truchas de un año de edad y en las adultas (figs. 19c; 60e).

La aparición de marcaje para parvalbúmina en otras regiones diencefálicas es mucho más tardía. Así, las primeras neuronas positivas a parvalbúmina se observan en los ejemplares de un año de edad en los núcleos pretectal, glomeruloso y geniculado lateral. Los elementos positivos en este estadio presentan las mismas características que en el adulto (figs. 18e,f; 19; 20a). Las neuronas marcadas en el núcleo pretectal son grandes, con un soma piriforme o globular y una única prolongación gruesa inmunoteñida (fig. 60d). Las neuronas que aparecen dispersas por el núcleo geniculado lateral son de menor tamaño y globulares (fig. 60b). Similares en su morfología son las que observamos en el núcleo glomeruloso, pero estas últimas presentan menor intensidad de tinción para parvalbúmina (fig. 60f).

El resto de los núcleos diencefálicos no presentan marcaje para parvalbúmina en ninguno de los estadios del desarrollo analizados (figs. 13; 15; 16; 18; 19; 20). 


\section{Mesencéfalo}

El mesencéfalo en la trucha arco iris está constituido por el tegmentum mesencefálico y el techo óptico. En ambas regiones aparece por primera vez inmunorreactividad para parvalbúmina en los animales juveniles de un año de edad, marcaje que se observa también en los animales adultos (figs. 18e,f; 19; 20; 21a).

En el techo óptico encontramos neuronas inmunopositivas a parvalbúmina en todos los estratos, pero principalmente en el óptico y en el periventricular. Además, son más abundantes en las regiones dorsomedial y ventrolateral del techo mesencefálico. Las células están débilmente teñidas, son esféricas o fusiformes, y algunas presentan cortas prolongaciones orientadas perpendicularmente a la laminación tectal (fig. 61a,b).

El torus longitudinalis se desarrolla en la línea media del mesencéfalo uniendo los dos hemitechos ópticos a partir de 15 días después de la eclosión. No se observan células positivas a parvalbúmina en el torus longitudinalis en ninguno de los estadios analizados.

En el tegmentum mesencefálico se observa por primera vez inmunotinción para parvalbúmina en los animales juveniles de 1 año de edad en el núcleo del nervio oculomotor, en el núcleo del nervio troclear, en el núcleo lateral de la válvula y en el torus semicircularis. Las neuronas del núcleo del nervio oculomotor, dispuestas a ambos lados de la región mas ventral del ventrículo mesencefálico, son de tamaño grande, con un soma esférico y una sola prolongación teñida dirigida lateroventralmente (fig. 62c). Las neuronas del núcleo del nervio troclear son de menor tamaño, redondeadas, y en ellas no podemos observar prolongaciones 
inmunoteñidas. Se encuentran dispuestas dorsalmente a los haces parvalbúmina positivos del fascículo longitudinal medial (fig. 62d).

En el núcleo lateral de la válvula observamos inmunotinción para parvalbúmina en pequeñas células esféricas, sin marcaje en sus prolongaciones y distribuidas de modo homogéneo por toda la extensión del núcleo (fig. 61d). En el torus semicircularis observamos células inmunopositivas dispuestas entre los fascículos negativos de los tractos mesencefálicos (fig. 61c).

\section{Metencéfalo}

La expresión de parvalbúmina en el metencéfalo comienza 6 días después de la eclosión de los ejemplares, si bien es relativamente temprana con respecto al resto de las regiones encefálicas. En el estadio de 6 días se observan células débilmente teñidas, formando un estrato monocelular en las regiones dorsocentrales de la placa cerebelar (cuerpo del cerebelo presuntivo), así como un grupo celular, también débilmente positivo, en las zonas laterales (lóbulo vestibulolateral presuntivo) (fig. 63a). Por su ubicación y posterior desarrollo morfológico a lo largo de la ontogenia, las hemos identificado como células de Purkinje inmaduras. El marcaje en esta región va extendiéndose progresivamente a lo largo de los estadios sucesivos del desarrollo de 15 días (fig. 14a-d) y 21 días de edad a los tres componentes cerebelares (cuerpo del cerebelo, válvula del cerebelo y lóbulo vestibulolateral). En el estadio de un mes posteclosión ya se observan las células de Purkinje positivas en toda la extensión rostrocaudal del metencéfalo.

Posteriormente, a los tres meses después de la eclosión, pueden observarse las dendritas inmunorreactivas de las células de Purkinje extendiéndose por la capa molecular (fig. 63b). En el siguiente estadio estudiado, a los seis meses después de la eclosión (figs. 16b,c; 17a-c; 63c,d), las células de Purkinje aumentan en número y 
tamaño, así como en intensidad de tinción, y sus dendritas inmunorreactivas son de mayor longitud.

En los animales de un año de edad y en los adultos podemos observar el patrón definitivo de marcaje para parvalbúmina en el cerebelo (figs. 20; 21a-d; 63e,f). Las células de Purkinje presentan sus cuerpos celulares de morfología piriforme, intensamente teñidos, observándose en ocasiones las porciones iniciales del axón. Las dendritas de estas neuronas se dirigen hacia el estrato molecular, donde se ramifican profusamente.

Por debajo de la monocapa de células de Purkinje encontramos terminales axónicos positivos para parvalbúmina que delimitan los cuerpos celulares negativos de las neuronas de proyección del cerebelo en los teleósteos, las células euridendroides (fig. 63e,f).

No observamos marcaje para parvalbúmina en la eminencia granular en ninguno de los estadios analizados.

\section{Mielencéfalo}

El mielencéfalo es una de las regiones encefálicas en las que primero aparecen elementos positivos para parvalbúmina durante el desarrollo del Sistema Nervioso de la trucha arco iris.

Es en el estadio de 6 días tras la eclosión cuando observamos por primera vez células inmunopositivas a parvalbúmina. Se trata de neuronas localizadas a nivel del núcleo tangencial y del núcleo vestibular magnocelular del área octavolateral (fig. 66a). A partir de los 15 días posteclosión, las neuronas envían prolongaciones inmunoteñidas que se agrupan en dos haces inmunorreactivos diferentes (fig. 66b,c). Uno se dirige ipsilateralmente en dirección caudal por el tracto vestibuloespinal, en el que observamos fibras marcadas durante todo el desarrollo (figs. 14c-e; 17b-d; 21b-d). 
El otro cruza la línea media mielencefálica y algunas de sus fibras realizan contactos sobre la célula de Mauthner contralateral (fig. 64c,d), mientras que el resto penetran en el fascículo longitudinal medial (figs. 13f,g; 14; 17; 20; 21). Estas últimas se dirigen a regiones mesencefálicas y diencefálicas, realizando contactos sobre los núcleos de los nervios oculomotor y troclear, así como sobre el núcleo del fascículo longitudinal medial (figs. 60a,c,e; 62). Durante el desarrollo juvenil, las células de los núcleos tangencial y vestibular magnocelular van aumentando progresivamente de tamaño (fig. 66c). Por último, en los animales adultos se observan células esféricas de pequeño tamaño e intensamente teñidas en el núcleo tangencial (fig. 66d), y neuronas más grandes pero más debilmente marcadas en el núcleo vestibular magnocelular (fig. $66 e)$.

En los juveniles de tres meses de edad se observan neuronas positivas para parvalbúmina dentro de los núcleos inferior, medio y superior de la formación reticular. Al alcanzar los seis meses de edad (fig. 17a-c) estas neuronas aumentan su tamaño, y su forma es claramente poligonal, observándose el inicio de dos o tres prolongaciones marcadas (fig. 64a). En los ejemplares de un año y en los adultos las neuronas de los núcleos de la formación reticular son de mayor tamaño, más intensamente teñidas y sus prolongaciones pueden observarse con claridad (fig. 64b).

En el estadio de seis meses después de la eclosión observamos marcaje para parvalbúmina en el núcleo del nervio trigémino y en las células de Mauthner. El núcleo del nervio trigémino aparece en las regiones más rostrales del mielencéfalo, ventralmente al cuarto ventrículo (fig. 17a). Las neuronas de este núcleo, débilmente positivas para parvalbúmina, son alargadas, a veces piriformes, pudiéndose observar en ocasiones el inicio de prolongaciones positivas (fig. 65a). Este marcaje se mantiene en los animales de un año de edad y en los adultos (figs. 21a; 65b).

Las células de Mauthner presentan su soma débilmente inmunoteñido, y dendritas marcadas de gran tamaño, así como su axón (fibra de Mauthner), discurriendo por la porción más dorsal del fascículo longitudinal medial (figs. 17b; 
64a). La inmunorreactividad para parvalbúmina se mantiene en los animales juveniles de un año y en los adultos (figs. 21b; 64c,d).

En las truchas de un año de edad aparece por primera vez marcaje para parvalbúmina en el núcleo del nervio abducens, núcleo del nervio facial, núcleo del nervio vestibuloacústico, núcleo del nervio glosofaríngeo y núcleo del nervio vago. En el estadio adulto (fig. 21b-e), los elementos neuronales positivos para parvalbúmina descritos en los núcleos de los nervios craneales presentan las mismas características morfológicas, si bien son algo mayores en su tamaño, y algo mas fuerte la intensidad de tinción para parvalbúmina.

El núcleo del nervio abducens se localiza en posición ventrolateral al cuarto ventrículo. Las neuronas de este núcleo están muy débilmente marcadas y son de morfología más o menos globular (fig. 65c).

Caudalmente al núcleo del nervio abducens pueden observarse neuronas parvalbúmina positivas en posición ventrolateral con respecto al ventrículo, y dorsolateralmente al fascículo longitudinal medial. Se trata de neuronas mas alargadas o piriformes, de las que en ocasiones surgen prolongaciones que se dirigen ventrolateralmente. Unas se localizan en posición más dorsomedial, y las hemos identificado como pertenecientes al núcleo del nervio facial (fig. 65 d), mientras que las que se sitúan en posición más ventrolateral pertenecen al núcleo del nervio vestibuloacústico (fig. 65d).

Los núcleos del nervio glosofaríngeo (fig. 65e) y del nervio vago (fig. 65f) también resultan marcados para parvalbúmina. Las neuronas de ambos núcleos son grandes, redondeadas, y se disponen en la zona central ventralmente al núcleo del fascículo solitario.

$\mathrm{Al}$ alcanzar el estadio de $250^{\circ}$-día en el Sistema Nervioso Periférico observamos por primera vez inmunorreactividad a parvalbúmina en el ganglio asociado al nervio vestibuloacústico, situado junto a la pared ventrolateral del mielencéfalo. Se trata de 
células esféricas de pequeño tamaño, con una tinción débil y sin prolongaciones marcadas (fig. 67a). En el estadio de $300^{\circ}$-día, las neuronas parvalbúmina positivas del ganglio vestibuloacústico presuntivo son algo mayores, y su patrón de tinción es homogéneo. En el estadio siguiente, $350^{\circ}$-día, se observa como desde estas neuronas surgen dos prolongaciones marcadas. Las prolongaciones van siendo de mayor longitud en los estadios siguientes, alevines recién eclosionados y de 2 días de edad (fig. 67b). Se dirigen tanto hacia las ramas nerviosas vegetativas como hacia el encéfalo. En el estadío de 6 días de edad, las fibras procedentes del ganglio penetran en el encéfalo, tomando diferentes direcciones. Algunas se dirigen hacia la línea media, y tras decusarse, contactan con la célula de Mauthner contralateral. Otras se integran en el tracto vestibuloespinal (fig. 67c) dirigiéndose a los núcleos vestibulares del área octavolateral, donde desde el estadio de 15 días (fig. 14c,e) hasta el adulto (fig. 21a-c) podemos observar botones terminales positivos a parvalbúmina sobre células débilmente positivas (fig. 66e) o negativas (fig. 66f) de dichos núcleos. A lo largo del desarrollo juvenil aumenta el número y tamaño de las células marcadas en el ganglio vestibuloacústico, así como el de fibras inmunorreactivas que salen de él (fig. 67d), hasta alcanzar el patrón definitivo en el adulto (fig. 67e).

\section{Médula espinal}

Las primeras células positivas a parvalbúmina en la médula espinal se observan en el estadio de tres meses tras la eclosión. Se trata de células poligonales de tamaño medio, débilmente marcadas y localizadas en las astas ventrales de la médula espinal. Por su morfología y localización, estas neuronas han sido identificadas como motoneuronas (fig. 68a).

En los juveniles de seis meses (fig. 17e), las neuronas parvalbúmina positivas son algo mayores, observándose en algunas de ellas el esbozo de prolongaciones dendríticas marcadas (fig. 68b). En este estadio puede observarse además una débil 
inmunotinción en los axones de las células de Mauthner que discurren rostrocaudalmente por la médula espinal.

En los animales juveniles de un año y en los adultos (fig. 21f), las motoneuronas positivas para parvalbúmina son células grandes, de morfología ovoide o esférica y que presentan varias prolongaciones dendríticas marcadas (fig. 68c,d). Además, en estos estadios se observaron gran cantidad de fibras inmunorreactivas en los sistemas fibrilares ascendentes, descendentes y comisurales que discurren por la médula espinal. (fig. 68c,d)

Al igual que ocurría en el telencéfalo, en la médula espinal de los ejemplares mayores de un año de edad y en los adultos, hemos observado células que expresan parvalbúmina con las características morfológicas de células gliales. Se trata de células grandes, alargadas, con dos prolongaciones que surgen de polos opuestos del cuerpo celular y que se disponen entre los paquetes fibrilares de las regiones más mediales de la médula (fig. 68e,f). Todas estas características nos inclinan a identificar, tentativamente, a estas células como oligodendrocitos. 


\section{CALBINDINA D-28K}

El marcaje con el anticuerpo monoclonal McAB anti-calbindina D-28k se detecta siempre en elementos gliales. Aparece por primera vez en el estadio de $200^{\circ}$ día. En este momento del desarrollo del Sistema Nervioso de la trucha arco iris observamos inmunotinción en elementos gliales de la región hipotalámica (figs. 22c,d; 72a) y en el polo ventral de la línea media del mielencéfalo (figs. 22e; 80a) y la médula espinal (figs. 22f; 83a,b). Al avanzar en el desarrollo podemos identificar esos elementos como células de glía radial. El marcaje en otras regiones encefálicas aparece en estadios posteclosión. Así, tras la eclosión aparece marcaje en cuerpos celulares situados en la región periventricular del techo óptico (figs. 24e; 75a). A los 2 días después de la eclosión aparecen elementos inmunorreactivos en el metencéfalo, correspondientes a los precursores de la glía de Bergmann (fig. 78a,b). La expresión más tardía se produce en el telencéfalo, donde aparecen tanicitos inmunorreactivos periventriculares a partir del estadio de 6 días tras la eclosión (fig. 70a).

\section{Telencéfalo}

El telencéfalo es la región donde la expresión de elementos inmunorreactivos para calbindina D-28k es más tardía. El primer momento en el que observamos inmunorreactividad es 6 días tras la eclosión. En niveles caudales del telencéfalo aparecen algunos cuerpos celulares positivos a calbindina situados en la región ventral de la línea media, junto al ventrículo telencefálico (fig. 70a). La posterior evolución de su morfología y localización nos ha permitido identificarlos como tanicitos periventriculares.

En el estadio de 15 días aparecen nuevos tanicitos inmunorreactivos en niveles más rostrales del telencéfalo. Así observamos algunos localizados a nivel del área dorsodorsal telencefálica (fig. 70b). En niveles más caudales, observamos 
inmunorreactividad en dos grupos de tanicitos periventriculares, uno a nivel del área dorsodorsal telencefálica y otro a nivel del área ventrodorsal telencefálica, quedando libre de marcaje el área dorsomedial comprendida entre ambas (figs. 25b,c; 70c). Estos tanicitos envían prolongaciones que se dirigen ventrolateralmente hacia regiones subpiales.

En los alevines de 21 días y de un mes el marcaje se va haciendo gradualmente más extenso. Aumenta el número de tanicitos inmunorreactivos, cuyas prolongaciones se distribuyen por regiones cada vez más amplias de las distintas áreas ventrales telencefálicas (fig. 70d). La comisura anterior aparece libre de inmunorreactividad (figs. 70e).

El marcaje alcanza su máximo de complejidad en los hemisferios telencefálicos en el estadio de tres meses posteclosión. A partir de ese momento y hasta alcanzar la edad adulta el patrón de marcaje no varía (figs. 27b-d; 30b-d; 71). Los tanicitos positivos poseen prolongaciones inmunorreactivas dirigidas lateralmente (fig. 71d), se localizan en toda la superficie periventricular exceptuando la correspondiente al área ventroventral en la zona de transición con los bulbos olfatorios (fig. 71a), y el área ventrodorsal en niveles más caudales ya próximos al área preóptica diencefálica (fig. 70f). En los niveles más caudales se observa una región dentro del área dorsolateral en la que no aparecen prolongaciones inmunorreactivas para calbindina D-28k (fig. 71b).

El marcaje en el bulbo olfatorio aparece muy tardíamente, en los alevines de 15 días de edad (fig. 25a). Observamos marcaje entre los fascículos del nervio olfatorio que llegan a la superficie ventral del bulbo (fig. 69a). Posteriormente, en el estadio de un mes tras la eclosión, aparece marcaje en cuerpos celulares de tanicitos de localización periventricular de los que salen prolongaciones que atraviesan todo el espesor del bulbo olfatorio. El marcaje para calbindina D-28k en el bulbo olfatorio muestra un aspecto homogéneo e invariable desde este estadio hasta la edad adulta (figs. 27a; 30a; 69b-d). 


\section{Diencéfalo}

La expresión de calbindina D-28k en el diencéfalo es muy temprana. Los primeros elementos inmunorreactivos detectados se observan en el esbozo del hipotálamo en el estadio de $200^{\circ}$-día. Hemos observado cuerpos celulares inmunoteñidos en la zona más ventral de la línea media (fig. 22c), de los que surgen procesos inmunorreactivos que se dirigen hacia niveles más caudales, formando un casquete subpial alrededor de la superficie ventral del hipotálamo embrionario (figs. 22d; 72a).

En estadio de $300^{\circ}$-día, el marcaje localizado en el hipotálamo se hace más extenso, apareciendo mayor cantidad de cuerpos celulares y fibras inmunorreactivas para calbindina D-28k en la región del túber presuntivo (fig. 23d). Además, observamos algunos cuerpos celulares inmunoteñidos en la región del tálamo dorsal, situados periventricularmente, y de los que salen cortas prolongaciones en dirección ventrolateral (figs. 23c,d; 73a).

A los 350-día, aumenta el número y la intensidad de tinción de elementos marcados en la región del túber. Las prolongaciones que surgen de los cuerpos celulares periventriculares del tálamo dorsal son mucho más evidentes. Se dirigen lateralmente hacia las regiones del pretectum y del núcleo rotundo en los niveles más rostrales, y hacia el núcleo difuso del torus lateralis y el núcleo difuso del lóbulo inferior en los más caudales. Además, aparece marcaje en cuerpos celulares de localización periventricular en el área preóptica (fig. 72b).

En el siguiente estadio, el de la eclosión, aumenta el número de células marcadas en la región del área preóptica y del túber, así como el de fibras inmunorreactivas que atraviesan el tálamo hacia las estructuras pretectales y del tubérculo posterior descritas en el estadio anterior (fig. 24d,e). Además, aparece inmunorreactividad para calbindina D-28k en un nuevo grupo de células periventriculares situadas en el tálamo 
ventral, por debajo del grupo descrito en el estadio anterior (fig. 24e). De estas células surgen prolongaciones inmunoteñidas orientadas perpendicularmente a la línea media (fig. 73b).

En los alevines de 2 días, además de hacerse más extenso el marcaje en las regiones talámicas e hipotalámicas anteriormente citadas, aparecen nuevos grupos de células inmunorreactivas en la región periventricular del área preóptica, localizadas en el núcleo preóptico periventricular y en el núcleo preóptico (fig. 72c). En el hipotálamo observamos un grupo de células marcadas en el núcleo posterior periventricular. En todos los casos de las células surge una prolongación que se dirige lateralmente hacia regiones subpiales.

A partir de los 6 días después de la eclosión el patrón de marcaje se generaliza a todos los niveles diencefálicos (fig. 73c). Así, aparecen células inmunorreactivas en las paredes de los recesos ventriculares posterior y lateral (figs. 25g; 26a,b; 74a,b), con prolongaciones muy cortas, de tal manera que queda libre de prolongaciones la región hipotalámica que rodea a los recesos.

A lo largo del desarrollo va aumentando el número de células inmunorreactivas en todas las regiones diencefálicas. Hemos observado inmunotinción en cuerpos celulares de la región central periventricular diencefálica, si bien aparecen regiones sin inmunotinción entre las regiones positivas (figs. 72d-f, 73d-f). En algunas ocasiones vemos cuerpos celulares inmunorreactivos desplazados de la región periventricular (fig. 73f). Encontramos inmunotinción para calbindina D-28k en el área preóptica y en todos los niveles talámicos. Los procesos inmunorreactivos de las células positivas a calbindina D-28k se distribuyen por todo el espesor diencefálico, alcanzando los núcleos del pretectum y del tubérculo posterior (figs. 25d-g; 27e-g; 28a; 30e,f; 31). En los niveles más caudales los núcleos del túber presentan células periventriculares marcadas y procesos inmunorreactivos distribuidos por toda su extensión, mientras que la zona ventral que rodea los recesos hipotalámicos queda libre de procesos inmunorreactivos positivos para calbindina D-28k (fig. 74b,c). 
Dentro de la habénula el marcaje es muy escaso, observándose algunos cuerpos celulares periventriculares y fibras inmunorreactivas dispersas (fig. 74d).

\section{Mesencéfalo}

Dentro de las dos regiones en las que se divide el mesencéfalo, techo óptico y tegmentum, el marcaje para calbindina D-28k aparece primero en el tegmentum, en estadios embrionarios. En el techo óptico se observan los primeros elementos inmunorreactivos tras la eclosión.

En el estadio de $250^{\circ}$-día observamos marcaje en los niveles tegmentales más caudales. Está localizado en cuerpos celulares de la base de la línea media mesencefálica (fig. 77a). En el siguiente estadio, 300-día, aparecen células inmunorreactivas en la base del ventrículo mesencefálico (figs. 23e; 77b). En el estadio de $350^{\circ}$-día estas células positivas presentan prolongaciones marcadas que se dirigen ventralmente hacia regiones subpiales (fig. 77c). En el estadio de eclosión el marcaje en la línea media se extiende desde la zona más dorsal a la más ventral (fig. 24f). Además, aumenta el número de cuerpos celulares inmunoteñidos, así como el área ocupada por sus prolongaciones inmunopositivas de recorrido dorsoventral. En la zona más rostral del tegmentum aparece marcaje en células de ubicación periventricular distribuidas por toda la base del ventrículo mesencefálico, que envían prolongaciones ventralmente hasta el límite con el diencéfalo (figs. 24e,f; 77d).

A partir de la eclosión, el número de células inmunorreactivas localizadas tanto en la línea media, como en la base del ventrículo mesencefálico, va aumentando gradualmente, así como el de fibras que surgiendo de los cuerpos celulares se distribuyen por todos los niveles tegmentales. En el estadio de 15 días, podemos observar como la linea media del tegmentum queda libre de cuerpos celulares inmunorreactivos y se encuentra ocupada por prolongaciones inmunorreactivas quedando las células restringidas a la región periventricular (figs. 26b; 77e). El patrón 
observado a partir de este momento del desarrollo no sufre modificaciones sustanciales en estadios posteriores (figs. 28b,c; 32). La única variación se observa en los juveniles de un año de edad y en los adultos, en los que pueden observarse cuerpos celulares inmunorreactivos para calbindina D-28k desplazados de la región periventricular al interior del tegmentum (fig. 77f).

En el techo óptico los primeros elementos inmunorreactivos para calbindina D28k aparecen en el estadio de eclosión (fig. 24e). El marcaje se observa en cuerpos celulares periventriculares de la zona dorsolateral del techo óptico (fig. 75a). En el estadio de 2 días después de la eclosión la región marcada es más amplia, observándose mayor número de células inmunorreactivas en la región periventricular del techo óptico. A los 6 días se observa como de esas células inmunorreactivas surgen prolongaciones inmunoteñidas que atraviesan todos los estratos del techo óptico (fig. 75b). Este marcaje es más abundante en zonas rostrales, llegando a desaparecer en los niveles más caudales del techo óptico.

El área ocupada por los procesos inmunorreactivos a calbindina D-28k va haciéndose cada vez mayor a lo largo del desarrollo, aumentando tanto dorsal como ventralmente y a lo largo del eje rostrocaudal (fig. 25d-g). Así, al alcanzar el estadio de tres meses de edad, el marcaje alcanza su máxima extensión, quedando tan sólo libres de cuerpos celulares y procesos inmunorreactivos estrechas porciones de las regiones dorsocentral y ventrolateral (fig. 75c). En los animales de seis meses (figs. 27e-g; 28; 29a), un año y adultos (figs. 30e,f; 31; 32; 33a; 75d-f), el patrón de marcaje es el mismo, si bien el número de células inmunorreactivas y la longitud de los procesos positivos que de ellas salen va siendo progresivamente mayor, paralelamente al aumento de tamaño que se produce en el techo óptico a lo largo de toda la vida del animal.

En los alevines de 15 días de edad podemos observar inmunorreactividad para calbindina D-28k en el territorio presuntivo del torus longitudinalis (fig. 25f,g). Se observan células inmunorreactivas en la línea media de esta estructura (fig. 76a). Al 
avanzar en el desarrollo aumenta el número de células inmunorreactivas. En los alevines de un mes las células inmunorreactivas se localizan en las paredes ventrales del torus longitudinalis que están en contacto con los hemitechos ópticos. En los juveniles de tres meses (fig. 76b) y seis meses (fig. 76c) se observa como de estas células surgen prolongaciones marcadas que se dirigen dorsalmente hacia regiones subpiales de la estructura. En los juveniles de un año y en los adultos, el torus longitudinalis ya no se encuentra encerrado entre los dos hemitechos, sino que presenta una superficie ventral libre en contacto con el ventrículo, en la que se sitúan los cuerpos celulares inmunorreactivos para calbindina D-28k (figs. 31; 32; 33a; 76d). Las células presentan procesos inmunorreactivos que se dirigen hacia la superficie dorsal del torus longitudinalis.

\section{Metencéfalo}

Los primeros elementos inmunorreactivos para calbindina D-28k en el metencéfalo se observan a los 2 días de edad en las porciones ventrolaterales (fig. 78a) y dorsocentrales (fig. 78b) de la placa metencefálica. Por su morfología y localización estos cuerpos celulares fueron identificados como pertenecientes a la glía de Bergmann. Además, aparecen cuerpos celulares inmunoteñidos de localización periventricular.

En el siguiente estadio estudiado, 6 días después de la eclosión, las células gliales de Bergmann positivas presentan mayor intensidad de tinción, y se localizan en la región del estrato de las células de Purkinje (fig. 78c). Además se observan otras células inmunopositivas para calbindina D-28k dispersas por la capa de los granos, de morfología esférica y pequeño tamaño. A lo largo de toda la extensión rostrocaudal de la placa metencefálica aparecen cortas fibras inmunorreactivas en la capa molecular (fig. 78d). 
A los 15 días de edad el marcaje es similar al descrito anteriormente, si bien el número de células inmunorreactivas es mayor y las prolongaciones en la capa molecular son más numerosas (fig. 26a-d). Queda solamente libres de células y fibras una franja en la línea media del cuerpo del cerebelo (fig. 78f), así como el esbozo de la eminencia granular (fig. 78e). A partir de los 21 días el marcaje presenta el patrón definitivo. En los estadios juveniles (figs. 28b,c; 29a-c) se produce un aumento gradual en el número y tamaño de elementos inmunorreactivos en paralelo al crecimiento de todas las regiones metencefálicas hasta que se alcanza el estado adulto (figs. 32; 33a-d). Aparece inmunotinción para calbindina D-28k en todas las regiones en las que se divide el metencéfalo: cuerpo del cerebelo, válvula del cerebelo, y lóbulo vestibulolateral (fig. 79). Así, vemos células gliales de Bergmann inmunoteñidas, a nivel del estrato de las células de Purkinje, y otros cuerpos celulares inmunoteñidos y fibras dispersas en el seno del estrato granular. En el estrato molecular aparece un intenso marcaje fibrilar, constituido por procesos inmunopositivos paralelos entre sí perpendiculares a la superficie cerebelar. Además, en las regiones de la válvula del cerebelo observamos ependimocitos marcados con prolongaciones inmunoteñidas que se dirigen al interior del cerebelo.

\section{Mielencéfalo}

Esta región, junto con el diencéfalo, son las primeras en las que aparece inmunorreactividad para calbindina D-28k. En el estadio de $200^{\circ}$-día observamos inmunorreactividad en cuerpos celulares y fibras localizadas en la base de la línea media, en la primitiva placa del suelo (figs. 22e; 80a). En el siguiente estadio, el de $250^{\circ}$-día, aparece marcaje en cuerpos celulares agrupados en la región dorsolateral a nivel del núcleo del fascículo solitario presuntivo. De ellos salen prolongaciones inmunoteñidas que recorren todo el espesor del mielencéfalo hasta alcanzar la superficie ventral del mismo. 
A la edad de $300^{\circ}$-día, el marcaje se encuentra extendido ya prácticamente por toda la linea media del mielencéfalo embrionario (fig. 23 f-h). Está constituido por células inmunorreactivas en la mitad dorsal y cortas prolongaciones marcadas en la mitad ventral de la línea media. En secciones caudales, a nivel del núcleo reticular inferior, se observan además prolongaciones inmunorreactivas que, surgiendo de las células de la línea media, se dirigen a regiones subpiales ventrales del mielencéfalo (fig. 80b). Junto a éstas, pero situadas más lateralmente podemos observar prolongaciones marcadas que surgiendo del acumulo dorsal descrito en el estadio anterior se dirigen también hacia la superficie ventral (fig. 23i).

En el estadio de eclosión el marcaje se generalizó a todas las regiones mielencefálicas. Así, en los niveles más rostrales, pueden observarse células inmunoteñidas para calbindina D-28k en posición subpial por toda la superficie dorsal del mielencéfalo. Además, las prolongaciones inmunorreactivas procedentes de esas células ocupan el espesor del mielencéfalo (figs. 24g-i; 80c), alcanzando las fibras positivas toda la extensión periventricular de las paredes ventrales y laterales. En las regiones más caudales, en los niveles en que aparece la oliva, sólo se observan cuerpos celulares inmunorreactivos en la porción mas dorsal de la línea media, quedando restringidas las prolongaciones inmunorreactivas a la mitad ventral del mielencéfalo (figs. 24j; 80d).

En el estadio de 2 días tras la eclosión comienzan ya a observarse elementos celulares inmunorreactivos para calbindina D-28k en las regiones dorsales en las que previamente no aparecían. En los estadios sucesivos se hizo gradualmente más extenso el marcaje por la superficie dorsal (figs. 26c-e; 80e), hasta que en el estadio de 21 días después de la eclosión el marcaje alcanza la totalidad de las regiones mielencefálicas.

En los estadios posteriores va aumentando gradualmente el número de células inmunorreactivas localizadas en posición periventricular en la zona dorsal, así como también el número de procesos inmunorreactivos (figs. 29; 33; 80f; 81a). La única 
variación sustancial es la presencia de células inmunorreactivas dispersas por regiones más internas del mielencéfalo, que aparecen en los individuos juveniles de tres y seis meses, en los juveniles de un año y en los adultos (fig. 81b-d).

Adyacente a las regiones de los núcleos vestibulares y del área octavolateral se dispone el ganglio vestibuloacústico, que forma parte del Sistema Nervioso Periférico. En los embriones de $350^{\circ}$-día aparecen células gliales perineuronales en esta región, rodeando a neuronas que son inmunonegativas para calbindina D-28k (fig. 82a). En los estadios siguientes puede observarse como aumenta el número de células gliales perineuronales (fig. 24h). Al llegar al estadio de 6 días después de la eclosión observamos inmunorreactividad para calbindina D-28k en las ramas nerviosas que salen de este ganglio hacia las porciones sensitivas del sistema vestibular (fig. 82b). Está localizada en cuerpos celulares alargados con cortas prolongaciones que abrazan los fascículos axónicos negativos. A lo largo del desarrollo va aumentando el número de células gliales perineuronales positivas para calbindina D-28k (fig. 82c), hasta que en los animales adultos los elementos gliales inmunorreactivos a calbindina D-28k se distribuyen por toda la extensión del ganglio y sus ramas nerviosas eferentes (fig. 82d).

\section{Médula espinal}

Al igual que el hipotálamo y el mielencéfalo, la médula espinal muestra inmunorreactividad para calbindina D-28k en estadios muy tempranos del desarrollo. En el estadio de $200^{\circ}$-día observamos marcaje en cuerpos celulares y fibras localizadas en el polo ventral de la linea media de la médula espinal embrionaria (figs. 22f; 83a,b). En el estadio de $300^{\circ}$-día se observan además células inmunorreactivas localizadas en la zona central de la línea media. De ellas surgen procesos marcados que se dirigen ventralmente a regiones subpiales (fig. 23j). 
Posteriormente, a los $350^{\circ}$-día, aparece marcaje en cuerpos celulares localizados en el polo dorsal de la médula, a nivel de los corpúsculos epiteliales, y el marcaje descrito para los estadios anteriores se hace más abundante, ocupando los procesos inmunorreactivos todo el tercio ventral de la médula espinal embrionaria (fig. 83c). En el estadio de eclosión se observa una parcelación de la médula espinal tras la inmunotinción con calbindina D-28k. Así, podemos observar inmunomarcaje en cuerpos celulares de la línea media y en sus prolongaciones ocupando los tercios dorsal y ventral, mientras que la región lateral de la médula queda libre de inmunomarcaje (fig. 24k). Esta parcelación va desapareciendo durante el desarrollo, y así, al llegar al estadio de 15 días tras la eclosión, prácticamente toda la médula espinal presenta procesos inmunoteñidos para calbindina D-28k (figs. 26f; 83d). El patrón se mantiene durante el resto de la ontogenia, si bien el número y tamaño de los elementos inmunoteñidos va aumentando hasta que se alcanza el patrón definitivo. En los animales juveniles de tres meses y seis meses (figs. 29e; 83e), en los juveniles de un año, y en los adultos (fig. 33f), la observación detallada permite detectar cuerpos celulares de ependimocitos, junto con sus prolongaciones, fuertemente inmunorreactivas, que se extienden por la región periependimaria (fig. 83 f). 
Iconografía - 1 -

B) ICONOGRAFÍA 


\section{LISTA DE ABREVIATURAS}

ad: Asta dorsal de la médula espinal

AM: Campo anterior medial del bulbo olfatorio

AP: Área pretectal

APr: Área preóptica

av: Asta ventral de la médula espinal

BO: Bulbo olfatorio

CA: Comisura anterior

cac: comisura accesoria

CAns: Comisura ansulata

CC: Cuerpo del cerebelo

CG: Capa de los granos del bulbo olfatorio

CGl: Capa glomerular del bulbo olfatorio

$\mathrm{CH}$ : Comisura habenular

CHo: Comisura horizontal

cM: Célula de Mauthner

cme: Columna motora espinal

CP: Comisura posterior

CPl: Capa plexiforme del bulbo olfatorio

crc: Cresta cerebelar

Dd: Área dorsodorsal telencefálica

Dl: Área dorsolateral telencefálica

Dm: Área dorsomedial telencefálica

DPM: Campo dorsal posterior medial del bulbo olfatorio

EBC: Estrato blanco central del techo óptico

EFGS:Estrato fibroso y gris superficial del techo óptico

EGC: Estrato gris central del techo óptico

egr: Eminencia granular 
Iconografía - 3 -

EM: Estrato marginal del techo óptico

EO: Estrato óptico del techo óptico

EPV: Estrato periventricular del techo óptico

flm: Fascículo longitudinal medial

fM: Fibra de Mauthner

G: Glomérulo olfatorio

gr: capa de los granos del cerebelo

GVIII: Ganglio vestibuloacústico

H: Habénula

HIP: Hipotálamo

L: Campo lateral del bulbo olfatorio

ll: Lemnisco lateral

LVL: Lóbulo vestibulolateral

MED: Médula espinal

MES: Mesencéfalo

MET: Metencéfalo

MIEL: Mielencéfalo

mol: Capa molecular del cerebelo

NAPv: Núcleo anterior periventricular

NAT: Núcleo anterior del túber

NDL: Núcleo dorsolateral del tálamo

NDLI: Núcleo difuso del lóbulo inferior

NDM: Núcleo dorsomedial del tálamo

NDTL: Núcleo difuso del torus lateralis

Nflm: Núcleo del fascículo longitudinal medial

Nfsol: Núcleo del fascículo solitario

NG: Núcleo glomeruloso

NGL: Núcleo geniculado lateral

NGS: Núcleo gustatorio secundario 
Iconografía - 4 -

NIaov: Núcleo intermedio del área octavolateral

NIP: Núcleo interpeduncular

NLT: Núcleo lateral del túber

NLV: Nucleo lateral de la válvula

NM: Núcleo mamilar

NP: Núcleo pretectal

NPO: Núcleo preóptico

NPP: Núcleo preóptico periventricular

NPPv: Núcleo posterior periventricular

NPT: Núcleo posterior del túber

NR: Núcleo rotundo

NRa: Núcleo del rafe

NRi: Núcleo reticular inferior

NRL: Núcleo del receso lateral

NRm: Núcleo reticular medio

NRMT: Núcleo reticular mesencefálico-tegmental

NRO: Núcleo rojo

NRP: Núcleo del receso posterior

NRs : Núcleo reticular superior

Ntang: Núcleo tangencial

NVed: Núcleo vestibular descendente.

NVem: Núcleo vestibular magnocelular

NVL: Núcleo ventrolateral del tálamo

NVM: Núcleo ventromedial del tálamo

NI: Nervio olfatorio

NII: Nervio óptico

NIII: Núcleo del nervio oculomotor

NIV: Núcleo del nervio troclear

NV: Núcleo del nervio trigémino 
Iconografía - 5 -

NVI: Núcleo del nervio abducens

NVII: Núcleo del nervio facial

NVIII: Núcleo del nervio vestibuloacústico

NIX: Núcleo del nervio glosofaríngeo

NX: Núcleo del nervio vago

oli: Oliva

PL: Campo posterior lateral del bulbo olfatorio

PO: Placoda olfatoria

Pret: Pretectum

Pu: Capa de las células de Purkinje del cerebelo

QO: Quiasma óptico

TAL: Tálamo

tbs: Tracto bulboespinal

TD: Tálamo dorsal

Teg: Tegmentum

TEL: Telencéfalo

TL: Torus longitudinalis

tmcba: tracto mesencéfalocerebelar anterior

TO: Techo óptico

TP: Tubérculo posterior

TrO: Tracto óptico

TS: Torus semicircularis

ttbc: Tracto tectobulbar cruzado

ttbr: Tracto tectobulbar recto

TV: Tálamo ventral

tvsp: Tracto vestibuloespinal

V: Ventrículo

VC: Válvula del cerebelo

Vd: Área ventrodorsal telencefálica 
Iconografía - 6 -

Vl: Área ventrolateral telencefálica

VM: Campo ventromedial del bulbo olfatorio

VP: Campo ventral posterior del bulbo olfatorio

VPL: Campo ventral posterior lateral del bulbo olfatorio

Vv: Área ventroventral telencefálica 
Iconografía - 7 -

\section{FIGURAS 1-33}

Esquemas de secciones coronales del Sistema Nervioso Central de la trucha arco iris en los cuales se representa el marcaje detectado para cada una de las proteínas ligantes de calcio estudiadas. Los esquemas han sido ordenados por edades y, dentro de cada edad, desde los niveles más rostrales a los más caudales.

Figuras 1-12: Marcaje para calretinina.

Figura 1: Estadio de $200^{\circ}$-día.

Figura 2: Estadio de $300^{\circ}$-día.

Figura 3: Estadio de eclosión.

Figuras 4 y 5: Estadio de 15 días.

Figuras 6-8: Estadio de 6 meses.

Figuras 9-12: Estadio adulto.

Figuras 13-21: Marcaje para parvalbúmina.

Figuras 13 y 14: Estadio de 15 días.

Figuras 15-17: Estadio de 6 meses.

Figuras 18-21: Estadio adulto.

Figuras 22-33: Marcaje para calbindina D-28k.

Figura 22: Estadio de $200^{\circ}$-día.

Figura 23: Estadio de $300^{\circ}$-día.

Figura 24: Estadio de eclosión.

Figuras 25 y 26: Estadio de 15 días.

Figuras 27-29: Estadio de 6 meses.

Figuras 30 -33: Estadio adulto. 
Iconografía - 8 -

En la mitad derecha de cada esquema quedan recogidos los límites y denominación de los diferentes núcleos y tractos que aparecen a ese nivel de corte, y en la mitad izquierda representamos la distribución de la inmunorreactividad observada en cada sección. También indicamos, en un esquema del encéfalo de la trucha arco iris en vista dorsal, el nivel de corte y, en la parte superior izquierda de cada figura el estadio y la proteína a que corresponde el marcaje. La nomenclatura se corresponde con la de la lista de abreviaturas.

Barra de escala $=1 \mathrm{~mm}$. 


\section{FIGURA 34}

a) Vista ventral de un embrión de $150^{\circ}$-día procesado in toto con anticuerpos anti-calretinina. En la placoda olfatoria (PO), situada rostralmente al ojo, se observan células inmunorreactivas redondeadas.

b) Receptores olfatorios inmunorreactivos para calretinina en la mucosa olfatoria de un embrión de $300^{\circ}$-día.

c) Alevín de 21 días. Fascículos de axones olfatorios inmunopositivos para calretinina convergiendo en el nervio olfatorio (NI).

d) Detalle de los receptores olfatorios inmunorreactivos para calretinina en un ejemplar juvenil de 6 meses. Puede distinguirse la vesícula olfatoria en la porción más apical (flecha).

Barra de escala en a y c $=100 \mu \mathrm{m}$.

Barra de escala en $b=50 \mu m$.

Barra de escala en $\mathrm{d}=25 \mu \mathrm{m}$. 


\section{FIGURA 35}

a) Fibras inmunorreactivas para calretinina en el esbozo del bulbo olfatorio (BO) de un embrión de $300^{\circ}$-día.

b) Fibras inmunomarcadas para calretinina del nervio olfatorio arborizándose en glomérulos que se reúnen en campos terminales. En la imagen, correspondiente a un individuo juvenil de 3 meses, se observan el campo lateral (L) y el campo ventral posterior lateral (VPL).

c y d) Vistas generales del marcaje para calretinina en dos secciones coronales del bulbo olfatorio de un animal adulto (c es rostral y $\mathbf{d}$ es caudal). Pueden observarse distintos campos terminales de glomérulos: anterior medial (AM), dorsal posterior medial (DPM), lateral (L), posterior lateral (PL), ventromedial (VM), ventral posterior lateral (VPL), y ventral posterior (VP).

e) Glomérulos olfatorios (G) y granos (flechas) inmunorreactivos para calretinina en el bulbo olfatorio adulto.

f) Detalle de granos inmunorreactivos para calretinina en el bulbo olfatorio de un animal adulto.

Barra de escala en a y $\mathrm{f}=50 \mu \mathrm{m}$.

Barra de escala en $b-d=50 \mu m$.

Barra de escala en e $=100 \mu \mathrm{m}$. 


\section{FIGURA 36}

a) Células inmunorreactivas a calretinina localizadas en el área ventral telencefálica en un embrión de $350^{\circ}$-día.

b-e) Marcaje para calretinina en las áreas ventroventral (Vv) y ventrodorsal (Vd) del telencéfalo de la trucha arco iris en un alevín recién eclosionado (b), en un alevín de 6 días (c), en un juvenil de 3 meses (d) y en un juvenil de un año (e). Observamos que el número de células positivas para calretinina se incrementa a lo largo del desarrollo así como la longitud de las prolongaciones marcadas. En la figura d aparecen también campos terminales inmunorreactivos en el área dorsomedial telencefálica (Dm).

f) Marcaje para calretinina en las áreas dorsomedial (Dm) y ventrolateral (Vl) del telencéfalo adulto. Se observan tractos de fibras positivas (flechas) que proceden del diencéfalo y se resuelven en campos terminales en el área dorsomedial. También se ven cuerpos celulares marcados (flechas abiertas) en el área ventrolateral.

g) Imagen a mayor aumento de las fibras y neuronas positivas en el área ventrolateral telencefálica (Vl).

Barra de escala en $\mathrm{a}=50 \mu \mathrm{m}$.

Barra de escala en b-e y $g=100 \mu \mathrm{m}$.

Barra de escala en $\mathrm{f}=200 \mu \mathrm{m}$. 


\section{FIGURA 37}

a y b) Células inmunorreactivas a calretinina en el esbozo del área preóptica (APr) en el estadio de $200^{\circ}$-día. La figura a corresponde a una vista ventral de un embrión procesado in toto y la figura $\mathbf{b}$ a una sección coronal.

c y d) Marcaje para calretinina en el estadio de eclosión en el núcleo preóptico periventricular (NPP) (c) y en los núcleos preóptico (NPO) y anterior periventricular (NAPv) (d).

e y g) Inmunorreactividad para calretinina en el núcleo anterior periventricular en un ejemplar de 6 meses tras la eclosión (e) y en el adulto (g). Las células aumentan su tamaño y la longitud de sus prolongaciones.

f y h) Inmunotinción para calretinina en el núcleo preóptico a los 6 meses tras la eclosión (f) y en el adulto (h). Podemos observar que las células positivas extienden sus prolongaciones perpendicularmente a la pared ventricular.

Barra de escala en a-d y $\mathrm{h}=100 \mu \mathrm{m}$.

Barra de escala en e-g $=50 \mu \mathrm{m}$. 
Iconografía - 50 -

\section{FIGURA 38}

a-c) Evolución del marcaje para calretinina en el pretectum. Aparecen células inmunorreactivas en el área pretectal (AP), núcleo pretectal (NP), núcleo rotundo (NR) y núcleo geniculado lateral (NGL). a: alevín de 15 días. b: alevín de un mes. c: juvenil de 3 meses. En la figura a se observa también el núcleo dorsolateral del tálamo (NDL).

d-f) Micrografías de secciones coronales del encéfalo de la trucha arco iris adulta a nivel de pretectum. El marcaje para calretinina se localiza en el núcleo geniculado lateral (d), área pretectal (e) y núcleo pretectal (f). V: Ventrículo.

Barra de escala en a-c, e y $\mathrm{f}=100 \mu \mathrm{m}$.

Barra de escala en $d=200 \mu m$. 
Iconografía - 52 -

\section{FIGURA 39}

Expresión transitoria de calretinina en la habénula. Las primeras células inmunorreactivas se observan en el estadio de 15 días (a). El número de células positivas aumenta gradualmente como puede apreciarse en los estadios de un mes (b) y 3 meses (c), sin embargo, en estadios más avanzados del desarrollo el número de células marcadas disminuye y en el adulto desaparecen (d).

Barra de escala en a y $b=50 \mu m$.

Barra de escala en c y d $=100 \mu \mathrm{m}$. 


\section{FIGURA 40}

Evolución de la inmunotinción para calretinina en el tálamo (TAL) de la trucha arcoiris. En el estadio de $200^{\circ}$-día (a) se observa un único grupo de células inmunorreactivas. Progresivamente se incrementa el número de neuronas, así, en el estadio de eclosión (b) se observan dos grupos celulares, uno en el tálamo dorsal (TD), y otro en el tálamo ventral (TV). Al avanzar en el desarrollo aparecen más grupos de células inmunorreactivas localizados en los núcleos talámicos dorsomedial (NDM), dorsolateral (NDL), ventromedial (NVM) y ventrolateral (NVL), como se aprecia en secciones de alevines de 15 días (c es rostral y d es más caudal). En las figuras b, c y d se observa también marcaje en núcleos hipotalámicos como el núcleo anterior del túber (NAT), núcleo lateral del túber (NLT) y núcleo posterior periventricular (NPPv).

Barra de escala $=100 \mu \mathrm{m}$. 
Iconografía - 56 -

\section{FIGURA 41}

a) Sección coronal del encéfalo de un animal juvenil de 3 meses a nivel de los núcleos dorsales talámicos. Puede observarse como las neuronas positivas a calretinina del núcleo dorsomedial (NDM) se alinean en dirección al núcleo rotundo (NR) del pretectum. NDL: Núcleo dorsolateral del tálamo.

b-d) Marcaje para calretinina en los núcleos tálamicos de un ejemplar adulto. La figura b muestra el núcleo dorsolateral y la figura c el dorsomedial. En la figura d aparecen neuronas positivas en los núcleos ventromedial (NVM) y ventrolateral (NVL) del tálamo. Pueden observarse además células débilmente marcadas en los núcleos glomeruloso (NG) y rotundo (NR).

Barra de escala $=100 \mu \mathrm{m}$. 


\section{FIGURA 42}

a) Marcaje para calretinina en una sección coronal del hipotálamo caudal de un embrión de 250-día. HIP: hipotálamo.

b) Imagen de un embrión de $300^{\circ}$-día en la que ya podemos distinguir dos núcleos hipotalámicos positivos a calretinina: el núcleo difuso del lóbulo inferior (NDLI) y el núcleo del receso lateral (NRL).

c y d) Inmunotinción en los núcleos de los recesos hipotalámicos. En el estadio de eclosión (c) podemos observar neuronas positivas a calretinina pequeñas y esféricas en el núcleo del receso lateral (NRL). Aparecen otras células positivas con prolongaciones dirigidas lateralmente en el núcleo del receso posterior (NRP), que aumentan en número y tamaño a lo largo del desarrollo como observamos en un ejemplar juvenil de 6 meses (d).

e y f) Neuronas monopolares en el núcleo del receso lateral (e) y en el núcleo del receso posterior (f) en el estadio adulto. En el núcleo del receso posterior se aprecian además tractos fibrilares positivos a calretinina.

Barra de escala en a, c, e y $\mathrm{f}=100 \mu \mathrm{m}$.

Barra de escala en b y d $=50 \mu \mathrm{m}$. 
Iconografía - 60 -

\section{FIGURA 43}

Evolución del marcaje para calretinina en los núcleos anterior (NAT) y lateral (NLT) del túber (a, c y e), y en el núcleo posterior del túber (b, d y f). Se muestra el patrón de inmunotinción en el estadio de eclosión (a, b), en alevines de 15 días (c, d) y en juveniles de un año (e, f). A lo largo del desarrollo aumenta el número y tamaño de los elementos inmunorreactivos. El patrón de inmunorreactividad en los juveniles de un año es similar al encontrado en los individuos adultos.

Barra de escala en a-d $=50 \mu \mathrm{m}$.

Barra de escala en e $=200 \mu \mathrm{m}$.

Barra de escala en $\mathrm{f}=100 \mu \mathrm{m}$. 


\section{FIGURA 44}

a-c) Micrografías de secciones coronales del encéfalo de la trucha arco iris a nivel del diencéfalo caudal procesadas con anticuerpos anti-calretinina en diferentes estadios del desarrollo; a: alevín de 6 días, b: alevín de 15 días, c: alevín de un mes. Además del marcaje en estructuras diencefálicas como los núcleos glomeruloso (NG), difuso del torus lateralis (NDTL), del receso lateral (NRL) y mamilar (NM), se observan neuronas inmunorreactivas en el techo óptico (TO) y en el torus semicircularis (TS).

d-f) Marcaje para calretinina en diferentes núcleos del tubérculo posterior e hipotálamo en individuos adultos. Se observan neuronas esféricas sin prolongaciones marcadas en los núcleos glomeruloso (d) y mamilar (f), así como células con neuritas marcadas en los núcleos difuso del torus lateralis (NDTL) y difuso del lóbulo inferior (NDLI) (e).

Barra de escala $=100 \mu \mathrm{m}$. 


\section{FIGURA 45}

Expresión de calretinina durante el desarrollo de la retina de la trucha arco iris. En los embriones de $250^{\circ}$-día (a) aparecen células amacrinas positivas (flecha) en la parte central de la retina, mientras que el resto de las regiones se encuentra libre de marcaje. A los $300^{\circ}$-día (b), además de las células amacrinas (flechas), se observan células ganglionares positivas (flechas abiertas) ocupando mayor extensión de la retina. El marcaje se va extendiendo a regiones laterales, y aumenta la intensidad de inmunotinción en los elementos positivos, como puede observarse en una sección de un alevín de 6 días (c). En la misma imagen vemos las fibras positivas del nervio óptico en su porción inicial (flecha). En los juveniles de 3 meses (d), además del marcaje anteriormente descrito en células ganglionares (cabeza de flecha) y amacrinas (flecha), pueden distinguirse células bipolares positivas (flecha abierta).

Barra de escala en a y $b=100 \mu \mathrm{m}$.

Barra de escala en c y d $=50 \mu \mathrm{m}$. 


\section{FIGURA 46}

a) Inmunorreactividad para calretinina en el techo óptico (TO) de un embrión de $300^{\circ}$-día. Las células positivas se localizan junto al límite con el tegmentum mesencefálico (Teg).

b-d) A lo largo del desarrollo el marcaje para calretinina en el techo óptico se va extendiendo a la vez que se diferencian los distintos estratos. En el estadio de eclosión (b) pueden distinguirse células inmunomarcadas, así como fibras inmunorreactivas (flecha) en la porción mas externa. En los alevines de 15 días (c) el marcaje aparece distribuido en 3 estratos: estrato marginal (EM), estrato óptico (EO) y estrato periventricular (EPV). Al alcanzar los 3 meses de edad (d) ya se distinguen, además de los anteriormente citados, los estratos fibroso y gris superficial (EFGS), gris central (EGC) y blanco central (EBC). Aparecen fibras inmunorreactivas en EBC (flecha), EFGS y EO.

e) Fibras calretinina positivas en el nervio óptico (NII) y tracto óptico (TrO) en un juvenil de 3 meses de edad.

f) Detalle de las células positivas para calretinina en el techo óptico de un individuo juvenil de 6 meses. Se observan células débilmente teñidas, de morfología esférica, en los estratos marginal (flecha) y periventricular (cabeza de flecha), y otras fusiformes en el estrato gris central (flecha abierta).

Barra de escala en a-c $=50 \mu \mathrm{m}$.

Barra de escala en d y $\mathrm{f}=100 \mu \mathrm{m}$.

Barra de escala en e $=200 \mu \mathrm{m}$. 


\section{FIGURA 47}

a y b) Vistas panorámicas del patrón de distribución de calretinina en el techo óptico de un juvenil de un año (a), y de un adulto (b). El marcaje es similar en ambos estadios, exceptuando en el estrato marginal. EM: estrato marginal. EO: estrato óptico. EFGS: estrato fibroso y gris superficial. EGC: estrato gris central. EBC: estrato blanco central. EPV: estrato periventricular.

c y d) Detalle de los estratos marginal (EM) y óptico (EO) en un individuo de un año (c) y en un adulto (d). Mientras que aparecen células inmunorreactivas en el estrato marginal en individuos de un año, el mismo estrato está libre de inmunorreactividad en el adulto, pero se observan neuronas de características similares en la porción más externa del estrato óptico.

e y f) Detalle de distintos tipos celulares inmunorreactivos en el techo óptico de trucha arco iris adulta. Se aprecian diferentes morfologías celulares en los estratos periventricular (flechas abiertas), gris central (cabezas de flecha) y blanco central (flechas).

Barra de escala en a y $b=200 \mu \mathrm{m}$.

Barra de escala en c- $\mathrm{f}=50 \mu \mathrm{m}$. 
Iconografía - 70 -

\section{FIGURA 48}

Expresión transitoria de calretinina en el núcleo interpeduncular de la trucha arco iris. El marcaje se detecta por primera vez en el estadio de eclosión (a), y aumenta progresivamente durante el desarrollo, como se observa en alevines de 6 (b) y de 15 días (c). Al alcanzar el estado juvenil el número de células va disminuyendo progresivamente, como se aprecia en las imágenes correspondientes a individuos de 3 meses (d) y de un año (e), desapareciendo completamente en los adultos (f).

Barra de escala en a y $b=50 \mu m$.

Barra de escala en c y d $=100 \mu \mathrm{m}$.

Barra de escala en e y $\mathrm{f}=200 \mu \mathrm{m}$. 


\section{FIGURA 49}

a) Sección coronal del encéfalo de una trucha arco iris a nivel de los núcleos motores mesencefálicos en el estadio de eclosión, en la que se observan fibras inmunorreactivas a calretinina discurriendo por el fascículo longitudinal medial (flm).

b) Inmunotinción para calretinina en el tegmentum de un alevín de 6 días de edad. Pueden observarse fibras del fascículo longitudinal medial (flm) que se dirigen hacia el núcleo troclear (NIV), así como células marcadas en el núcleo lateral de la válvula (NLV) y en el núcleo reticular mesencefálico-tegmental (NRMT).

c y d) Inmunotinción para calretinina en los núcleos del fascículo longitudinal medial (Nflm), rojo (NRO) y glomeruloso (NG) de un alevín de 15 días (c) y en un juvenil de un año (d). Puede observarse un leve entramado fibrilar sobre las neuronas inmunomarcadas de estos núcleos.

e y f) Terminales calretinina-positivos que, procedentes del fascículo longitudinal medial (flm), contactan con las células de los núcleos motores del tegmentum (flechas) en un individuo adulto. NIII: Núcleo del nervio oculomotor. NIV: Núcleo del nervio troclear. V: Ventrículo. VC: Válvula del cerebelo.

Barra de escala en a y $f=50 \mu \mathrm{m}$.

Barra de escala en b y c $=100 \mu \mathrm{m}$.

Barra de escala en d y e $=200 \mu \mathrm{m}$. 


\section{FIGURA 50}

a-c) Micrografías de secciones coronales del encéfalo de la trucha arco iris a nivel del tegmentum mesencefálico, en las que se observan neuronas inmunorreactivas para calretinina en el núcleo lateral de la válvula (NLV), torus semicircularis (TS) y núcleo reticular mesencefálico-tegmental (NRMT). También se distinguen fibras inmunorreactivas en el fascículo longitudinal medial (flm). a y b: estadio de eclosión. c: alevín de 15 días.

d-g) Marcaje para calretinina en diferentes regiones del tegmentum en animales adultos. Distinguimos neuronas de diferentes morfologías con prolongaciones marcadas en el núcleo reticular mesencefálico-tegmental (d), y neuronas pequeñas, esféricas muy apelotonadas en el núcleo lateral de la válvula (e). En el torus semicircularis aparecen neuronas piriformes situadas junto a la base del ventrículo mesencefálico (f), y otras fusiformes situadas entre tractos fibrilares negativos (g).

Barra de escala $=100 \mu \mathrm{m}$. 


\section{FIGURA 51}

a-c) Evolución del marcaje para calretinina en el metencéfalo de la trucha arco iris. En el estadio de eclosión (a) aparecen células esféricas, sin prolongaciones marcadas, así como un tracto fuertemente inmunorreactivo (flecha). En alevines de 6 días (b) se observan granos con cortas prolongaciones marcadas. En la imagen c, correspondiente a un juvenil de 3 meses, además de fibras (flecha abierta), y granos positivos (cabeza de flecha), observamos células de Lugaro marcadas (flecha).

d) Vista general del marcaje para calretinina en el metencéfalo de trucha arco iris adulta. Pueden observarse granos en el cuerpo del cerebelo (CC) y en la eminencia granular (egr), y células de Lugaro en el lóbulo vestibulolateral (LVL).

e) Detalle de las células inmunorreactivas para calretinina en el cerebelo de la trucha arco iris adulta. Aparecen granos de pequeño tamaño (cabeza de flecha) y células de Lugaro más grandes, en las que en ocasiones se observa el inicio del axón (flecha).

f) Terminales inmunorreactivos para calretinina a nivel de las células de Purkinje inmunonegativas (asterisco). mol: capa molecular. Pu: capa de las células de Purkinje. gr: capa de los granos.

Barra de escala en a y $b=50 \mu \mathrm{m}$.

Barra de escala en c, e y $\mathrm{f}=100 \mu \mathrm{m}$.

Barra de escala en $d=200 \mu \mathrm{m}$. 
Iconografía - 78 -

\section{FIGURA 52}

a, c y e) Micrografías de secciones coronales del encéfalo de trucha arco iris que muestran las células inmunorreactivas para calretinina en el núcleo trigémino (flechas) en diferentes estadios de desarrollo. a: alevín de 6 días. c: juvenil de 6 meses. e: adulto.

b, $\mathbf{d}$ y f) Micrografías de secciones coronales del encéfalo de trucha arco iris que muestran la evolución del marcaje para calretinina en el núcleo gustatorio secundario. b: estadio de eclosión. d: juvenil de un mes. f: adulto.

Barra de escala a, c, e y $\mathrm{f}=100 \mu \mathrm{m}$.

Barra de escala en b y d $=50 \mu \mathrm{m}$. 


\section{FIGURA 53}

a) Marcaje para calretinina en los núcleos motores del mielencéfalo en un alevín de 15 días. Se observan células grandes pertenecientes a los núcleos del nervio facial (NVII) y del nervio vestibuloacústico (NVII), así como somas esféricos de menor tamaño pertenecientes al núcleo del nervio abducens (NVI).

b) Vista general del mielencéfalo de un ejemplar juvenil de un año a nivel de los núcleos de los pares craneales. Junto a las neuronas inmunorreactivas para calretinina correspondientes a los núcleos del nervio abducens (NVI), del nervio facial (NVII) y del nervio vestibuloacústico (NVIII), se observan células positivas de diferentes tamaños y morfologías pertenecientes al núcleo reticular medio (NRm).

c) Detalle de la figura b mostrando las neuronas esféricas del núcleo del nervio abducens (NVI), así como células y fibras correspondientes al núcleo reticular medio (NRm).

d) Detalle de la figura b donde se observan células fusiformes con largas prolongaciones marcadas en los núcleos de los nervios facial (NVII) y del nervio vestibuloacústico (NVIII), así como otras de gran tamaño y morfología ovoide y poligonal pertenecientes al núcleo reticular medio (NRm).

Barra de escala en a y $\mathrm{d}=100 \mu \mathrm{m}$.

Barra de escala en $b=200 \mu \mathrm{m}$.

Barra de escala en c $=50 \mu \mathrm{m}$. 


\section{FIGURA 54}

Marcaje para calretinina en los núcleos reticulares y del rafe. En secciones horizontales de embriones de $250^{\circ}$-día (a) se aprecian numerosas neuronas localizadas a nivel de los núcleos reticulares que envían sus prolongaciones reunidas en un tracto que se dirige hacia regiones más caudales. En el estadio de eclosión (b) ya pueden diferenciarse las neuronas pertenecientes al núcleo del rafe (NRa) de las del núcleo reticular superior (NRs). Las diferencias entre ambos grupos celulares se van acentuando durante el desarrollo, y en juveniles de 6 meses (c) se aprecia la diferencia existente en tamaño y patrón de ramificación entre las neuronas reticulares (flecha) y las pertenecientes al núcleo del rafe (flecha abierta). En el mielencéfalo adulto aparecen neuronas esféricas fuertemente inmunorreactivas con gruesas prolongaciones marcadas en el núcleo del rafe (d) y células de diferentes morfologías en los núcleos reticulares, en ocasiones de gran tamaño (flecha) (e y f).

Barra de escala en a, d, e y $\mathrm{f}=100 \mu \mathrm{m}$.

Barra de escala b y c $=50 \mu \mathrm{m}$. 
Iconografía - 84 -

\section{FIGURA 55}

Marcaje para calretinina en los núcleos vestibulares en alevines de 6 días (a, b, c) y juveniles de un año (d, e, f). Aparecen células inmunorreactivas para calretinina de morfología esférica en los núcleos intermedio del área octavolateral (NIaov) (a y d), tangencial (Ntang) (b y e) y vestibular descendente (NVed) (c y f), así como otras de forma ovoide de mayor tamaño en el núcleo vestibular magnocelular (NVem) (b y e). Sobre las neuronas de estos núcleos se aprecia un denso entramado de fibras inmunopositivas correspondientes al tracto vestibuloespinal (flechas). GVIII: ganglio vestibuloacústico.

Barra de escala en a-c, $\mathrm{d}$ y $\mathrm{f}=100 \mu \mathrm{m}$.

Barra de escala en e $=150 \mu \mathrm{m}$. 


\section{FIGURA 56}

a, c y e) Evolución del marcaje para calretinina en el núcleo del fascículo solitario a lo largo de la ontogenia de la trucha arco iris. En el estadio de $300^{\circ}$-día (a) se observan neuronas esféricas sin prolongaciones marcadas. En alevines de 6 días (c) ya empiezan a observarse células con prolongaciones inmunorreactivas, hasta que las neuronas adquieren la morfología piriforme y monopolar que podemos observar en los adultos (e).

b, d y f) Inmunorreactividad para calretinina en la oliva en diferentes estadios de desarrollo. El primer estadio en el que se observa marcaje es el de eclosión (b), aparecen pequeñas células esféricas sin prolongaciones marcadas, inmersas en un fino entramado de terminales calretinina positivos. A lo largo del desarrollo aumenta gradualmente la extensión del marcaje como observamos en secciones coronales de un juvenil de 3 meses (d) y de un adulto (f).

Barra de escala en a-c $=50 \mu \mathrm{m}$.

Barra de escala en $\mathrm{d}=100 \mu \mathrm{m}$.

Barra de escala en e y $\mathrm{f}=200 \mu \mathrm{m}$. 
Iconografía - 88 -

\section{FIGURA 57}

a y b) Neuronas inmunorreactivas para calretinina en el ganglio vestibuloacústico en un embrión de $350^{\circ}$-día (a) y en un juvenil de un año (b).

c y d) Fibras inmunorreactivas para calretinina (flechas) sobre las células de Mauthner inmunonegativas en ejemplares de 15 días (c) y de un año (d) de edad. Pueden observarse gruesas fibras marcadas (flechas abiertas) que se integran en el fascículo longitudinal medial (flm).

Barra de escala $=50 \mu \mathrm{m}$. 


\section{FIGURA 58}

a-e) Evolución del marcaje para calretinina en la médula espinal de la trucha arco iris. En embriones de $150^{\circ}$-día procesados in toto para calretinina (a) se observan neuronas piriformes monopolares en el mielencéfalo (MIEL) y la médula espinal (MED), alineadas a ambos lados de la linea media. Al avanzar en el desarrollo, aumenta gradualmente el número de neuronas inmunorreactivas, como puede observarse en secciones coronales de embriones de $350^{\circ}$-día (b) y de alevines de 2 días de edad (c). Al alcanzar el estadio de 15 días (d) pueden distinguirse dentro de la médula espinal interneuronas redondeadas (flechas) y motoneuronas (flecha abierta) inmunorreactivas. En juveniles de 6 meses (e) pueden distinguirse grandes motoneuronas (flecha) con una prolongación que sale de la médula espinal por la raíz medular ventral (flechas abiertas).

f-h) Inmunorreactividad para calretinina en la médula espinal de la trucha arco iris adulta. Pueden distinguirse interneuronas marcadas de diferentes morfologías (f); algunas bipolares (flecha abierta), otras semilunares (flecha), así como terminales inmunorreactivos para calretinina sobre elementos celulares negativos (cabezas de flecha). Se observa también marcaje en grandes motoneuronas (g) y en células de los corpúsculos epiteliales (h).

Barra de escala en a-e $=100 \mu \mathrm{m}$.

Barra de escala en $\mathrm{f}-\mathrm{h}=50 \mu \mathrm{m}$. 


\section{FIGURA 59}

a) Marcaje para parvalbúmina en el bulbo olfatorio de individuos juveniles de un año de edad. Se observan células esféricas pequeñas (flechas) y otras de mayor tamaño y morfología ovalada o piriforme (flechas abiertas).

b-e) Inmunorreactividad para parvalbúmina en el telencéfalo de la trucha arco iris. La figura b muestra células inmunorreactivas para parvalbúmina (flechas) en las áreas dorsodorsal (Dd) y dorsolateral (Dl) de un juvenil de 6 meses. En los animales adultos (c) el marcaje está mas extendido y se localiza en ependimocitos periventriculares (flecha abierta), fibras inmunorreactivas (flechas) y pequeñas neuronas esféricas en las áreas telencefálicas dorsomedial (Dm), dorsodorsal (Dd) y dorsolateral (Dd). A mayor aumento se muestran las neuronas (d) y los ependimocitos (e) en el telencéfalo de la trucha arco iris adulta.

Barra de escala en a, b y d $=100 \mu \mathrm{m}$.

Barra de escala en $\mathrm{c}=200 \mu \mathrm{m}$.

Barra de escala en e $=50 \mu \mathrm{m}$. 


\section{FIGURA 60}

a, c y e) Evolución del marcaje para parvalbúmina en el núcleo del fascículo longitudinal medial. En los alevines de 15 días (a) se observan neuronas marcadas y fibras inmunorreactivas que proceden del fascículo longitudinal medial (flm). Al avanzar en el desarrollo puede observarse la presencia de prolongaciones marcadas en las neuronas positivas, como se aprecia en secciones coronales el encéfalo de juveniles de 6 meses (c) y adultos (e).

b) Núcleo geniculado lateral en un individuo juvenil de un año. Se observa un denso entramado fibrilar y pequeñas neuronas inmunorreactivas para parvalbúmina.

d) Neuronas monopolares inmunorreactivas para parvalbúmina del núcleo pretectal de un individuo adulto.

f) Inmunorreactividad para parvalbúmina en el núcleo glomeruloso de una trucha arco iris adulta. Se observan pequeñas células esféricas teñidas sin prolongaciones marcadas (flechas).

Barra de escala en a y c $=50 \mu \mathrm{m}$.

Barra de escala en $b=200 \mu \mathrm{m}$.

Barra de escala en $\mathrm{d}=100 \mu \mathrm{m}$. 


\section{FIGURA 61}

a y b) Marcaje para parvalbúmina en el techo óptico de una trucha arco iris de un año. Se observan células inmunorreactivas en los estratos periventricular (EPV) y blanco central (EBC) (a), así como en los estratos óptico (EO) y fibroso y gris superficial (EFGS) (b).

c y d) Inmunotinción para parvalbúmina en el tegmentum de trucha arco iris adulta. Aparecen células marcadas entre paquetes de fibras inmunonegativas del torus semicircularis (c), y neuronas esféricas sin prolongaciones marcadas en el núcleo lateral de la válvula (d).

Barra de escala $=50 \mu \mathrm{m}$. 
Iconografía - 98 -

\section{FIGURA 62}

Marcaje para parvalbúmina en los núcleos de los pares craneales mesencefálicos. El marcaje se localiza en fibras procedentes del fascículo longitudinal medial (flm) que contactan con las células inmunonegativas de los núcleos del nervio troclear (NIV) y del nervio oculomotor (NIII) en los alevines de 15 días (a) y 3 meses (b). Al llegar al estadio juvenil de un año de edad las células que constituyen ambos núcleos presentan inmunorreactividad para parvalbúmina (c y d).

Barra de escala en a, b y d $=50 \mu \mathrm{m}$.

Barra de escala en c $=100 \mu \mathrm{m}$. 


\section{FIGURA 63}

Evolución del marcaje para parvalbúmina en el metencéfalo de la trucha arco iris. Los primeros elementos inmunorreactivos aparecen a los 6 días de edad (a) en células de Purkinje inmaduras a nivel del lóbulo vestibulolateral (LVL). La imagen b muestra el cuerpo del cerebelo de un juvenil de 3 meses; las células inmunorreactivas se alinean en la capa de las células de Purkinje (Pu) con sus dendritas extendiéndose por la capa molecular (mol), y no se observa marcaje en la capa de los granos (gr). En juveniles de 6 meses de edad pueden observarse células de Purkinje en la válvula del cerebelo (VC) (c) y en el lóbulo vestibulolateral (LVL) (d). En secciones coronales del cerebelo adulto (e y f) aumenta el tamaño de las células de Purkinje, así como la longitud de sus dendritas marcadas, que discurren por la capa molecular. En ocasiones se distingue el inicio de su axón marcado (cabeza de flecha). Se observan además campos terminales positivos sobre células euridendroides negativas (flechas).

Barra de escala en a y c $=100 \mu \mathrm{m}$.

Barra de escala en b y e $=200 \mu \mathrm{m}$.

Barra de escala en d y $f=50 \mu \mathrm{m}$. 
Iconografía - 102 -

\section{FIGURA 64}

a) Juvenil de 6 meses de edad. Inmunotinción para parvalbúmina en las células de Mauthner. Se marca intensamente tanto el cuerpo celular, como las dendritas (cabeza de flecha) que se extienden por el mielencéfalo, y el axón (flecha) que se integra en el fascículo longitudinal medial (flm). Se observan además neuronas reticulares inmunopositivas (flecha abierta).

b) Neurona reticular inmunorreactiva para parvalbúmina en una trucha arco iris adulta.

c y d) Secciones coronales de células de Mauthner a nivel rostral (c) y caudal (d). Se observan terminales inmunorreactivos para parvalbúmina que hacen contacto sobre ellas (flechas).

Barra de escala en $\mathrm{a}=100 \mu \mathrm{m}$.

Barra de escala en b, c y d $=50 \mu \mathrm{m}$. 
Iconografía - 104 -

\section{FIGURA 65}

a) Marcaje para parvalbúmina en el núcleo del nervio trigémino (NV) de un individuo juvenil de 6 meses.

b-f) Inmunorreactividad para parvalbúmina en los núcleos de los pares craneales mielencefálicos en la trucha arco iris adulta. Se observan las células de los núcleos del nervio trigémino (b; NV), nervio abducens (c; NVI), nervio facial (d; NVII), nervio vestibuloacústico (d; NVIII), nervio glosofaríngeo (e; NIX) y del nervio vago (f; NX). Las flechas en las figuras $\mathbf{d}$ y $\mathbf{f}$ señalan el axón de Mauthner inmunorreactivo para parvalbúmina discurriendo por el fascículo longitudinal medial (flm).

Barra de escala en $\mathrm{a}=50 \mu \mathrm{m}$.

Barra de escala en $b-f=100 \mu m$. 


\section{FIGURA 66}

Marcaje para parvalbúmina en los núcleos vestibulares de la trucha arco iris. Aparecen células débilmente inmunorreactivas en el núcleos vestibular magnocelular (NVem) y células más intensamente teñidas en el núcleo tangencial (Ntang), núcleos a los que además llegan fibras inmunopositivas procedentes del ganglio vestibuloacústico, como se aprecia en secciones coronales del encéfalo de alevines de 6 (a) y 15 días (b). En la figura c se muestra una vista general del marcaje en los núcleos vestibulares en el estadio de un año. Además de las neuronas inmunopositivas de los núcleos vestibular magnocelular y tangencial, se observan fibras inmunorreactivas que se dirigen hacia la línea media del encéfalo (flechas). A mayor aumento se muestra el marcaje que aparece en ejemplares adultos (d-f). Así se observan neuronas intensamente teñidas para parvalbúmina en el núcleo tangencial (d), neuronas débilmente teñidas rodeadas de terminales inmunopositivos en el núcleo vestibular magnocelular (e), y terminales positivos para parvalbúmina sobre células inmunonegativas en el núcleo vestibular descendente (f).

Barra de escala en a y c $=200 \mu \mathrm{m}$.

Barra de escala en b y d-f $=50 \mu \mathrm{m}$. 
Iconografía - 108 -

\section{FIGURA 67}

Evolución de la inmunorreactividad para parvalbúmina en el ganglio vestibuloacústico. Las primeras células inmunorreactivas se observan en el estadio de $250^{\circ}$-día (a). A los 2 días de edad (b) puede observarse mayor número de células positivas y con prolongaciones marcadas, algunas dirigiéndose a regiones sensoriales (flecha abierta) y otras hacia el mielencéfalo (flecha). En una sección sagital del encéfalo de un alevín de 6 días (c) se observa como las fibras que penetran en el mielencéfalo se integran en el tracto vestibuloespinal (flechas). A lo largo del desarrollo aumenta el número de células y fibras inmunopositivas en el ganglio vestibuloacústico, como se aprecia en secciones de juveniles de 3 meses (d) y de un año (e).

Barra de escala en a, b, d y e $=100 \mu \mathrm{m}$.

Barra de escala en $\mathrm{c}=100 \mu \mathrm{m}$. 


\section{FIGURA 68}

Inmunorreactividad para parvalbúmina en la médula espinal de trucha arco iris. En una sección coronal de la médula espinal de un juvenil de 3 meses (a) se observan células débilmente marcadas (flechas). A los 6 meses (b) las células positivas son de mayor tamaño y presentan cortas prolongaciones. En el adulto, el marcaje está más extendido (c), observándose inmunorreactividad en cuerpos celulares y tractos fibrilares. En imágenes a mayor aumento podemos ver motoneuronas (d), y en el polo ventral de la médula espinal (e) oligodendrocitos inmunorreactivos (flechas), dispuestos junto a los tractos fibrilares inmunorreactivos (f).

Barra de escala en a y c $=200 \mu \mathrm{m}$.

Barra de escala en b y $\mathrm{f}=50 \mu \mathrm{m}$.

Barra de escala en d y e $=100 \mu \mathrm{m}$. 


\section{FIGURA 69}

Marcaje para calbindina D-28k en el bulbo olfatorio (BO) de la trucha arco iris. El marcaje se observa por primera vez a los 15 días después de la eclosión (a) entre los fascículos del nervio olfatorio (NI) a su entrada en el bulbo olfatorio. En los alevines de un mes (b), además del marcaje en el nervio olfatorio se pueden observar fibras dispersas en el interior del bulbo olfatorio. En secciones coronales de individuos adultos (c y d) se observan tanicitos periventriculares (flechas abiertas) con prolongaciones que se reúnen en gruesos tractos marcados (flechas) y llegan hasta la capa plexiforme $(\mathrm{CPl})$ y la capa glomerular (CGl).

Barra de escala en a, c y d $=100 \mu \mathrm{m}$.

Barra de escala en $b=50 \mu \mathrm{m}$. 


\section{FIGURA 70}

Inmunorreactividad para calbindina D-28k en el telencéfalo de la trucha arco iris. Los primeros cuerpos celulares inmunorreactivos aparecen en la región ventral de la línea de separación de los dos hemisferios telencefálicos en alevines de 6 días (a). En secciones coronales del telencéfalo de alevines de 15 días (b) se observan tanicitos periventriculares con prolongaciones marcadas (flecha), localizados en el área dorsodorsal telencefálica (Dd). En niveles más caudales (c) aparece marcaje en tanicitos localizados en las áreas dorsodorsal y ventrodorsal $(\mathrm{Vd})$, y en sus prolongaciones que se dirigen hacia regiones subpiales ventrales (flechas). La región dorsomedial (Dm) está libre de marcaje. Posteriormente, a los 21 días (d), los tanicitos se disponen a lo largo de toda la línea media, y envían prolongaciones que contactan con la región subpial (flechas). En los alevines de un mes (e) aumenta en gran medida el número de fibras inmunorreactivas en la región ventral telencefálica, si bien la comisura anterior (CA) aparece libre de marcaje. En los juveniles de 3 meses (f) el marcaje se distribuye por todo el hemisferio, excepto en las regiones ventrales de los niveles más caudales que limitan con el diencéfalo (asterisco).

Barra de escala en a y $b=50 \mu \mathrm{m}$.

Barra de escala en c-f $=100 \mu \mathrm{m}$. 


\section{FIGURA 71}

a) Juvenil de un año. La región del área ventroventral telencefálica (Vv) que limita con los bulbos olfatorios no presenta tanicitos inmunorreactivos, que son muy abundantes e intensamente inmunoteñidos en el resto del telencéfalo.

b-d) Marcaje para calbindina D-28k en el telencéfalo de trucha arco iris adulta. Las prolongaciones inmunomarcadas ocupan todo el hemisferio excepto una pequeña porción del área dorsolateral (b; asterisco) y la región de la comisura anterior (c; CA). En la figura d se muestran a mayor aumento los tanicitos inmunorreactivos.

Barra de escala en a y c $=100 \mu \mathrm{m}$.

Barra de escala en $b=400 \mu \mathrm{m}$.

Barra de escala en $\mathrm{d}=50 \mu \mathrm{m}$. 


\section{FIGURA 72}

a) Embrión de $200^{\circ}$-día. Fibras inmunorreactivas para calbindina D-28k localizadas subpialmente a nivel del hipotálamo (HIP).

b-f) Evolución del marcaje para calbindina D-28k en el área preóptica (APr) de la trucha arco iris. En embriones de $350^{\circ}$-día (b) la inmunorreactividad aparece en cuerpos celulares periventriculares en el área preóptica. En los alevines de 2 días (c) pueden distinguirse dos grupos de células diferentes, uno a nivel del núcleo preóptico (NPO) y otro a nivel del núcleo anterior periventricular (NAPv). Al llegar al estadio de 15 días (d) se observan prolongaciones inmunomarcadas que surgen en sentido lateral hacia regiones subpiales desde los cuerpos celulares localizados a nivel del núcleo anterior periventricular. Estas prolongaciones se reúnen en un fascículo que alcanza porciones subpiales ventrales (flecha) en los juveniles de un mes (e). Al alcanzar la edad de 6 meses (f) el marcaje se generaliza a la mayor parte del área preóptica, si bien permanecen regiones libres de inmunorreactividad (asteriscos). TAL: Tálamo. TO: Techo óptico.

Barra de escala en a y $b=50 \mu \mathrm{m}$.

Barra de escala en c, d y $\mathrm{f}=100 \mu \mathrm{m}$.

Barra de escala en e $=200 \mu \mathrm{m}$. 


\section{FIGURA 73}

Expresión de calbindina D-28k en el diencéfalo de la trucha arco iris. En los embriones de $300^{\circ}$-día (a) aparecen cuerpos celulares inmunorreactivos localizados junto al ventrículo (V) a nivel del tálamo dorsal, con prolongaciones que se dirigen lateralmente (flechas). En el estadio de eclosión (b), las prolongaciones inmunorreactivas de las células localizadas en el tálamo dorsal alcanzan regiones subpiales (flechas), y aparecen dos nuevos grupos de células inmunorreactivas, uno en el tálamo ventral (flecha abierta) y otro en el túber (cabeza de flecha). En los alevines de 6 días (c), aunque quedan zonas libres de marcaje (asteriscos), el desarrollo de estos grupos celulares y la longitud de las fibras inmunorreactivas es mucho mayor, alcanzando todas ellas las regiones subpiales laterales (flechas). Durante el desarrollo juvenil (d, e; 6 meses) y en el adulto (f) el marcaje fibrilar se generaliza a todo el diencéfalo, aunque quedan franjas transversales libres de marcaje (asteriscos). Se observan cuerpos celulares en la línea media (cabezas de flecha), fibras inmunorreactivas (flechas abiertas), así como algunos cuerpos celulares desplazados de la línea media (flechas).

Barra de escala en a, e y $\mathrm{f}=50 \mu \mathrm{m}$.

Barra de escala en b y c $=100 \mu \mathrm{m}$.

Barra de escala en $d=200 \mu \mathrm{m}$. 


\section{FIGURA 74}

a) Marcaje para calbindina D-28k en el tegmentum (Teg), núcleo difuso del lóbulo inferior (NDLI), y núcleos del receso lateral (NRL) y del receso posterior (NRP) en un alevín de 6 días.

b) Inmunorreactividad para calbindina D-28k en cuerpos celulares localizados alrededor de los recesos hipotalámicos en un juvenil de 3 meses. Queda libre de marcaje una gran porción de los núcleos del receso lateral (NRL) y del receso posterior (NRP). Se observa gran cantidad de fibras inmunorreactivas en el núcleo difuso del lóbulo inferior (NDLI).

c) Inmunotinción para calbindina D-28k en los núcleos de los recesos hipotalámicos de un ejemplar adulto. Se observan cuerpos celulares inmunorreactivos periventriculares a nivel de los núcleos del receso lateral (NRL) y del receso posterior (NRP), así como algunas células esféricas marcadas alejadas de los recesos hipotalámicos (flechas).

d) Cuerpos celulares periventriculares y fibras dispersas inmunorreactivas a calbindina D28k en la habénula de un individuo juvenil de un año. V: ventrículo.

Barra de escala en $\mathrm{a}=200 \mu \mathrm{m}$.

Barra de escala en $b-d=100 \mu m$. 


\section{FIGURA 75}

a) Estadio de eclosión. Células inmunorreactivas para calbindina D-28k situadas alrededor del ventrículo mesencefálico que separa el techo óptico (TO) del tegmentum mesencefálico (Teg). En el tegmentum se observan fibras inmunomarcadas (flechas).

b-f) Evolución del marcaje para calbindina D-28k en el techo óptico de la trucha arco iris. Se observan células inmunorreactivas, de localización periventricular, cuyas prolongaciones cruzan todos los estratos tectales. Los asteriscos marcan las regiones dorsomedial y ventrolateral del techo óptico que quedan libres de marcaje durante todo el desarrollo. b: alevín de 6 días. c: juvenil de 3 meses. d: juvenil de 6 meses. e y f: adulto.

Barra de escala en $\mathrm{a}=50 \mu \mathrm{m}$.

Barra de escala en $b=100 \mu m$.

Barra de escala en c $-\mathrm{f}=400 \mu \mathrm{m}$. 
Iconografía - 126 -

\section{FIGURA 76}

Evolución del marcaje para calbindina D-28k en el torus longitudinalis de la trucha arco iris.

a) Alevín de 15 días. Se observan células inmunomarcadas en la parte central del torus longitudinalis (flecha).

b y c) Las células inmunorreactivas que limitan lateralmente el torus longitudinalis (flecha) envían prolongaciones marcadas que alcanzan la superficie dorsal (flecha abierta). El asterisco indica la región limitante del techo óptico que carece de inmunorreactividad para calbindina D-28k. b: juvenil de 3 meses. c: juvenil de 6 meses.

d) Adulto. Se observan células redondeadas localizadas en el límite con el ventrículo mesencefálico (V).

Barra de escala $=100 \mu \mathrm{m}$. 


\section{FIGURA 77}

a) Imagen de una sección coronal a nivel del tegmentum de un embrión de $250^{\circ}$-día. El marcaje para calbindina D-28k se localiza en cuerpos celulares de la placa del suelo.

b) Células inmunorreactivas a calbindina D-28k en la base del ventrículo mesencefálico (V) de un embrión de $300^{\circ}$-día.

c-e) Evolución del marcaje en el tegmentum mesencefálico. Los cuerpos celulares inmunorreactivos se localizan en la zona dorsal de la línea media y en la base del ventrículo mesencefálico (cabezas de flecha), y envían prolongaciones inmunomarcadas hacia regiones subpiales ventrales (flechas). La línea media tegmental queda ocupada por prolongaciones inmunomarcadas (flechas abiertas). c: embrión de 350-día. d: estadio de eclosión. e: alevín de 15 días.

f) Vista general de una sección coronal del tegmentum de una trucha arco iris adulta. Además de cuerpos celulares localizados en posición periventricular, pueden observarse otros aislados, en zonas internas del tegmentum (flechas).

Barra de escala en a y $b=50 \mu m$.

Barra de escala en c y d $=100 \mu \mathrm{m}$.

Barra de escala en e y $\mathrm{f}=200 \mu \mathrm{m}$. 


\section{FIGURA 78}

Evolución del marcaje para calbindina D-28k en el metencéfalo de la trucha arco iris. A los 2 días de edad se observan células inmunorreactivas (flechas) en regiones laterales (a) y centrales (b) de la placa cerebelar. En el estadio de 6 días tras la eclosión (c y d) aumenta el número de células inmunorreactivas (flechas), y aparecen además fibras marcadas (flechas abiertas). A los 15 días posteclosión (e y f) se observa más claramente la laminación metencefálica, y aparecen células y fibras marcadas en toda su extensión, excepto en el esbozo de la eminencia granular (e; asterisco) y en una banda central (f; asteriscos) del cuerpo del cerebelo (CC) y el lóbulo vestibulolateral (LVL). mol: capa molecular. Pu: capa de las células de Purkinje. gr. capa de los granos.

Barra de escala en a-d= $50 \mu \mathrm{m}$.

Barra de escala en e y $\mathrm{f}=100 \mu \mathrm{m}$. 


\section{FIGURA 79}

a) Sección coronal del cuerpo del cerebelo de un juvenil de 6 meses. El marcaje para calbindina D-28k se observa en fibras apelotonadas en la capa molecular (mol), así como en las células gliales de Bergmann de la capa de las células de Purkinje (Pu) y fibras y células inmunorreactivas dispersas por la capa de los granos (gr). Quedan libres de inmunorreactividad dos zonas localizadas dorsal y ventralmente en la línea media del metencéfalo (asteriscos).

b) Vista panorámica de una sección coronal del cerebelo adulto procesada con anticuerpos anti-calbindina D-28k. El marcaje se distribuye de modo amplio por el cuerpo del cerebelo (CC), el lóbulo vestibulolateral (LVL) y la eminencia granular (egr).

c y d) Elementos inmunorreactivos a calbindina D-28k en el cuerpo del cerebelo (c) y la válvula del cerebelo (d). Se observan células de Bergmann (flechas abiertas) en la capa de células de Purkinje (Pu) y cuerpos celulares inmunorreactivos (cabezas de flecha) en la capa de los granos (gr), así como gran número de fibras marcadas en la capa molecular (mol), y menos abundantes, en la capa de los granos. Obsérvese que la laminación difiere en las dos estructuras, siendo la capa mas externa en el cuerpo del cerebelo la molecular, mientras que en la válvula del cerebelo es la granular. Además, aparecen cuerpos celulares esféricos de localización periventricular (d; flechas) en la válvula del cerebelo.

Barra de escala en a y c $=200 \mu \mathrm{m}$.

Barra de escala en $b=400 \mu \mathrm{m}$.

Barra de escala en $d=50 \mu \mathrm{m}$. 


\section{FIGURA 80}

Evolución del marcaje para calbindina D-28k en el mielencéfalo de la trucha arco iris. Los primeros elementos marcados se observan a los $200^{\circ}$-día en la placa del suelo (a), donde se observan células situadas dorsalmente (flecha) y fibras ventralmente (flecha abierta). A los $300^{\circ}$-día (b) aparecen prolongaciones que se dirigen a regiones subpiales ventrales (flechas). Al alcanzar el estadio de eclosión, en secciones rostrales (c) se distinguen células inmunorreactivas en la pared ventricular dorsal (flecha abierta), y en ocasiones se observa como sus prolongaciones abrazan el fascículo longitudinal medial (flecha). En secciones caudales (d) los cuerpos celulares se localizan en el polo dorsal de la línea media (flecha) y el tercio ventral del mielencéfalo (flecha abierta) se encuentra ocupado por prolongaciones. En los alevines de 6 días (e) aumenta el número de células marcadas de la pared dorsal (flecha abierta), que envían prolongaciones a las regiones ventrales (flechas) limitantes con el ganglio vestibuloacústico (GVIII). El marcaje en la línea media lo forman prolongaciones muy apelotonadas e intensamente marcadas (cabeza de flecha). Al avanzar en el desarrollo, el marcaje se generalizó a todas las regiones mielencefálicas, como se observa en una sección coronal de un individuo juvenil de 3 meses (f).

Barra de escala en a y $b=50 \mu \mathrm{m}$.

Barra de escala en c-e $=100 \mu \mathrm{m}$.

Barra de escala en $\mathrm{f}=200 \mu \mathrm{m}$. 


\section{FIGURA 81}

a y b) Secciones coronales del mielencéfalo de una trucha arco iris adulta a nivel de los núcleos de los nervios facial y vestibuloacústico (a) y a nivel de la cresta cerebelar (crc) y del núcleo del fascículo solitario (Nfsol) (b). El marcaje fibrilar para calbindina D-28k se distribuye homogéneamente en toda la extensión de ambas secciones.

c y d) Detalles del marcaje para calbindina D-28k en el mielencéfalo adulto en la región de la línea media (c) y en la región lateral (d). Además de los cuerpos celulares de localización periventricular (flecha abierta) se observan células marcadas en regiones más internas (flechas).

Barra de escala en $\mathrm{a}=400 \mu \mathrm{m}$.

Barra de escala en $b=200 \mu \mathrm{m}$.

Barra de escala en c y d $=100 \mu \mathrm{m}$. 


\section{FIGURA 82}

Inmunorreactividad para calbindina D-28k en el ganglio vestibuloacústico (GVIII).

a) Embrión de $350^{\circ}$-día. Células gliales perineuronales (flechas) en el esbozo del ganglio vestibuloacústico. MIEL: mielencéfalo.

b) Alevín de 6 días. Se observan fibras inmunorreactivas (flechas) que acompañan a la rama nerviosa eferente del ganglio vestibuloacústico.

c y d) Células gliales perineuronales (flechas) en un individuo juvenil de un mes (c) y en un adulto (d).

Barra de escala en a y d $=50 \mu \mathrm{m}$.

Barra de escala en $b=200 \mu \mathrm{m}$.

Barra de escala en $\mathrm{c}=50 \mu \mathrm{m}$. 


\section{FIGURA 83}

Marcaje para calbindina D-28k en la médula espinal de la trucha arco iris. En una sección horizontal (a) y en otra coronal (b) de un embrión de 200-día se observa inmunotinción en cuerpos celulares (flechas) y fibras localizados en la porción ventral correspondiente a la placa del suelo. En el estadio de $350^{\circ}$-día (c) se observa marcaje también en el polo dorsal de la médula espinal embrionaria. A lo largo del desarrollo el marcaje se va generalizando hasta ocupar toda la extensión de la médula espinal, como se aprecia en la imagen d, que muestra una sección coronal de la médula de un alevín de 15 días. En estadios posteriores se mantiene este patrón de inmunorreactividad constituido por cuerpos celulares periependimarios (flecha) y fibras, como observamos en juveniles de 6 meses (e) y adultos (f).

Barra de escala en a-c $=100 \mu \mathrm{m}$.

Barra de escala en d y e $=200 \mu \mathrm{m}$.

Barra de escala en $\mathrm{f}=50 \mu \mathrm{m}$. 
Discusión -1-

\section{DISCUSIÓN}




\section{PROTEÍNAS LIGANTES DE CALCIO EN LA ONTOGENIA DEL SISTEMA NERVIOSO DE LA TRUCHA ARCO IRIS}

En la presente Memoria de Tesis Doctoral hemos analizado los patrones de aparición y distribución de tres proteínas ligantes de calcio, parvalbúmina, calbindina D-28k, y calretinina, a lo largo de la ontogenia del Sistema Nervioso de la trucha arco iris, Oncorhynchus mykiss. Para ello hemos empleado anticuerpos monoclonales contra parvalbúmina y calbindina D-28k, y policlonales contra calretinina, siguiendo el método inmunocitoquímico indirecto de la avidina-biotina peroxidasa. Hemos obtenido marcaje específico para las tres proteínas en diferentes elementos celulares tanto en el Sistema Nervioso Central como en el Sistema Nervioso Periférico de la trucha arco iris.

Las tres proteínas objeto de nuestro estudio han sido tradicionalmente consideradas como marcadores neuronales específicos dentro del Sistema Nervioso, tanto en mamíferos (Baimbridge y Miller, 1982; García-Segura y cols., 1984; Arai y cols., 1991; Résibois y Rogers, 1992; Rogers y Résibois, 1992) como en peces teleósteos (Miguel-Hidalgo y cols., 1991; Losier y Matsubara, 1990; Vecino y cols., 1993; Briñón y cols., 1994; Arévalo y cols., 1995b). En la trucha arco iris, la inmunotinción para calretinina se localiza exclusivamente en somas neuronales a lo largo del desarrollo, en consonancia a lo descrito previamente en el Sistema Nervioso de teleósteos adultos (Arévalo y cols., 1995b; López, 1996). El marcaje para parvalbúmina aparece mayoritariamente en somas neuronales, pero en los estadios de un año y adulto se observaron también ependimocitos y oligodendrocitos interfasciculares marcados. Este marcaje glial ha sido también descrito previamente en la médula espinal de la trucha arco iris adulta (López, 1996). 
No hemos encontrado marcaje para calbindina D-28k en elementos neuronales en ninguno de los estadios de desarrollo de la trucha arco iris; por el contrario, el marcaje siempre aparece en elementos gliales. Sin embargo, trabajos previos indican que esta proteína es un marcador neuronal en peces teleósteos (Maler y cols., 1984; Dechesne y cols., 1988; Denizot y cols., 1988; Miguel-Hidalgo y cols., 1991; Losier y Matsubara, 1990; Vecino y cols., 1993; Presson, 1994; Djebar y cols., 1995). Esta divergencia en los resultados puede deberse a que los estudios previos fueron realizados utilizando anticuerpos policlonales contra calbindina D-28k, que presentan inmunorreactividad cruzada con calretinina (Résibois y Rogers, 1992; Rogers y Resibóis, 1992), mientras que nosotros hemos empleado un anticuerpo monoclonal. Tras experimentos de Western blot con anticuerpos policlonales anti-calbindina D28k, sólo aparece una banda correspondiente a una proteína de 28 kDa en peces, mientras que aparecen dos, una de $28 \mathrm{kDa}$ correspondiente a la calbindina D-28k y una de 29 kDa correspondiente a la calretinina en el cerebro de vertebrados tetrápodos (Parmentier y cols., 1987). Se obtienen los mismos resultados si se realiza el Western blot con una mezcla del anticuerpo policlonal contra calretinina y el anticuerpo McAB 300 contra calbindina D-28k que nosotros hemos utilizado (Schwaller y cols., 1993). Estos datos parecen indicar que en teleósteos sólo existe una proteína ligante de calcio en este rango de peso molecular, y que los anticuerpos policlonales contra calbindina D-28k y contra calretinina, obtenidos a partir de proteínas purificadas de mamíferos y aves, reconocerían una sola proteína en esta clase de peces.

Por otra parte, experimentos de caracterización del anticuerpo monoclonal McAB 300 mediante inmunoblot en homogenados de cerebro de trucha común Salmo trutta fario indican que podría reconocer una proteína ligante de calcio diferente, la calbindina D-9k (Becerra y cols., 1996). En ese sentido, cabe considerar que el peso molecular de la S-100, otra proteína ligante de calcio de la misma familia, se encuentra en el mismo rango de peso molecular, aproximadamente $10 \mathrm{kDa}$ (Donato, 1991). Dicha proteína ha sido detectada inmunocitoquímicamente con anticuerpos 
específicos en células gliales radiales y en astrocitos (Buwalda y cols., 1994; Velasco, 1994).

Aunque la naturaleza molecular del antígeno reconocido por este anticuerpo está aún en discusión, la tinción inmunocitoquímica con el anticuerpo McAB 300 contra calbindina D-28k es una herramienta neurohistológica útil en el estudio de la ontogenia del Sistema Nervioso en teleósteos, al marcar específicamente distintos tipos de células gliales durante el desarrollo. Nuestros resultados en la trucha arco iris muestran que la presencia de cuerpos celulares periventriculares y de procesos inmunorreactivos orientados radialmente, correspondientes a ependimocitos y glía radial, respectivamente, se mantienen durante todo el desarrollo y en el adulto. Los cuerpos celulares inmunorreactivos que observamos alejados de las regiones periventriculares, así como muchas de las prolongaciones dispersas por diferentes regiones del encéfalo y la médula espinal pueden ser de naturaleza astrocitaria. Dentro del Sistema Nervioso Periférico, el marcaje para calbindina D-28k se ha localizado en células gliales perineuronales.

Se ha descrito que la glía radial, encargada de dirigir la migración neuronal durante el desarrollo embrionario (Rakic, 1972), puede mantenerse en el adulto, como ocurre en el cerebelo (glía de Bergmann) e hipocampo de mamíferos (Mori y cols., 1990; Reichenbach, 1990), y en diferentes regiones del encéfalo de vertebrados anamniotas (King, 1966). Además de cumplir las funciones que desempeñan las células ependimarias adultas, podrían estar encargadas de dirigir la migración celular que se produce indefinidamente en teleósteos, al mantenerse el crecimiento del Sistema Nervioso durante toda la vida del animal (Bauchot y cols., 1979). Por otra parte, la glía radial y los astrocitos comparten características como la expresión de proteínas de filamentos intermedios, tales como nestina, vimentina y proteína glial fibrilar ácida (Dahl y cols., 1981; Benjelloun-Touimi y cols., 1985; Hockfield y McKay, 1985; Le Vine y Goldman, 1988; Tohyama y cols., 1992), y se ha descrito que la glía radial se transforma en astrocitos en numerosas regiones del Sistema 
Nervioso Central cuando la migración neuronal ha finalizado (Schmechel y Rakic, 1979).

Durante el desarrollo del Sistema Nervioso Central, la primera proteína ligante de calcio en expresarse de las que hemos estudiado es la calretinina, concretamente a los $150^{\circ}$-día en el mielencéfalo y en la médula espinal. Con un ligero retraso, a los $250^{\circ}$-día, se detectaron elementos gliales marcados con el anticuerpo monoclonal McAB 300 contra calbindina D-28k en la placa del suelo de regiones diencefálicas, mielencefálicas y de la médula espinal. La más tardía en aparecer es la parvalbúmina, a los 6 días después de la eclosión, y se localiza en neuronas de los núcleos vestibulares del mielencéfalo y en las células de Purkinje del cerebelo.

La secuencia de aparición de las tres proteínas es diferente en el Sistema Nervioso Periférico. La más temprana en su expresión es también la calretinina, que se observa en células de la placoda olfatoria a los $150^{\circ}$-día. La parvalbúmina, a diferencia de lo que ocurre en el Sistema Nervioso Central, aparece durante el desarrollo embrionario en células ganglionares del ganglio vestibuloacústico a los 250-día. El marcaje para calbindina D-28k es el más tardío, ya que aparece en células gliales del ganglio vestibuloacústico en el estadio de $350^{\circ}$-día. Por tanto, dentro del ganglio vestibuloacústico, la inmunorreactividad para las tres proteínas ligantes de calcio aparece casi a la vez, y evoluciona en paralelo para las tres a lo largo de la ontogenia, con un aumento gradual en el número y tamaño de los elementos inmunorreactivos

Los patrones de evolución del marcaje a lo largo del desarrollo del Sistema Nervioso Central son diferentes para las tres proteínas estudiadas. La calbindina D28k comienza a expresarse en el diencéfalo, mielencéfalo y médula espinal embrionarios. Con un cierto retraso, pero también en estadios embrionarios, se detecta marcaje en el mesencéfalo. Después de la eclosión aparece inmunorreactividad en el telencéfalo y en el metencéfalo. La calretinina comienza a 
desarrollarse en los embriones en el mielencéfalo y la médula espinal, posteriormente en el diencéfalo, mesencéfalo y telencéfalo. La inmunorreactividad para calretinina en el metencéfalo se observa por primera vez en estadios posteclosión. La parvalbúmina, en cambio, no se expresa en estadios embrionarios, apareciendo marcaje en regiones diencefálicas (núcleo del fascículo longitudinal medial), metencefálicas (células de Purkinje) y mielencefálicas (neuronas de los núcleos vestibulares) en los primeros días tras la eclosión. El marcaje para parvalbúmina en el telencéfalo, mesencéfalo y médula espinal aparece ya en estadios juveniles.

De las tres proteínas estudiadas, la calretinina es la única que ha mostrado un patrón de expresión transitoria (células positivas durante el desarrollo que son negativas en el adulto) en la habénula hipotalámica, en el núcleo interpeduncular del tegmentum y en el estrato marginal del techo óptico. Distintos procesos pueden explicar estos fenomenos de expresión transitoria: apoptosis de las poblaciones neuronales inmunorreactivas, cese de la expresión de la proteína, o en el caso del techo óptico, migración de las células inmunopositivas del estrato marginal al estrato óptico.

Los patrones de evolución del marcaje para calretinina y calbindina D-28k muestran un paralelismo con los obtenidos tras análisis del desarrollo relativo de las diversas regiones encefálicas en distintas especies de teleósteos (Pouwels, 1978a,b,c,d; Bäuerle y Rahmann, 1993; Tomoda y Uematsu, 1996; Toyoda y Uematsu, 1994), en los que se demuestra la maduración tardía que presentan el telencéfalo y el metencéfalo respecto al resto de regiones encefálicas. Además, durante el desarrollo embrionario, la expresión de calretinina sigue un gradiente de desarrollo rostrocaudal similar al descrito tras estudios de morfogénesis en el diencéfalo de la trucha común Salmo trutta fario (Corujo y Anadón, 1990). Dentro del techo óptico tanto calretinina como calbindina D-28k se expresan siguiendo el gradiente de desarrollo rostrocaudal y lateromedial que se ha descrito previamente en estudios morfológicos del desarrollo de esta región en teleósteos (Pinganaud, 1980). 
Además, el patrón de expresión de calretinina en los estratos retinorecipientes sigue una evolución paralela al establecimiento de las aferencias retininanas en el techo óptico, que se establecen en el primer tercio rostral al inicio del desarrollo del alevín, y alcanzan las zonas caudales al final del desarrollo (Mansour-Robaey y Pinganaud, 1990). No hemos encontrado correspondencia en la evolución del marcaje para parvalbúmina con ningún proceso morfogenético conocido durante el desarrollo del Sistema Nervioso Central de la trucha arco iris.

Como hemos indicado, la calbindina D-28k aparece sólamente en células gliales radiales, astrocitos y ependimocitos en el Sistema Nervioso Central de la trucha arco iris. La parvalbúmina aparece principalmente en elementos neuronales, pero también hemos detectado su presencia en ependimocitos y oligodendrocitos interfasciculares. Los ependimocitos positivos a parvalbúmina presentan localización similar a los elementos positivos para calbindina D-28k en el telencéfalo y la médula espinal. La expresión de parvalbúmina en ependimocitos es tardía, a partir del año de edad, momento a partir del cual podría darse una colocalización parcial de las dos proteínas en células gliales del telencéfalo y la médula espinal de la trucha arco iris. En este sentido, en cultivos mixtos de células nerviosas telencefálicas se ha descrito la colocalización de calbindina D-28k y parvalbúmina en células gliales (Crespo y cols., 1995). En el resto de las regiones la parvalbúmina aparece en células neuronales en las que nunca hemos observado inmunorreactividad para calbindina D-28k.

En trabajos previos en mamíferos, se ha descrito que calbindina D-28k y calretinina muestran diferentes grados de colocalización (Rogers y Résibois, 1992), siempre en células neuronales. Esta circunstancia no se produce en la trucha arco iris, ya que el marcaje para calbindina D-28k aparece en células gliales, mientras que la calretinina es un marcador exclusivamente neuronal.

Se ha visto la existencia de colocalización de calretinina y parvalbúmina en diferentes poblaciones neuronales adultas de reptiles (Martínez-Guijarro y Freund, 
1992), aves, (Rogers, 1989a), y mamíferos (Miettinen y cols., 1992), así como de modo transitorio durante el desarrollo, en la corteza cerebral del mono (Yan y cols., 1995). Además, se ha descrito que en algunas regiones existe un solapamiento entre la distribución de calretinina y la de parvalbúmina en el encéfalo de la rata, lo que sugiere la existencia de colocalización de ambas proteínas (Arai y cols., 1991; Résibois y Rogers, 1992). En cuanto a su distribución en la trucha arco iris, existen diversas zonas en las que hemos descrito neuronas inmunorreactivas para las dos proteínas. Sin embargo los patrones de expresión son completamente diferentes, ya que la expresión de calretinina precede a la de parvalbúmina durante el desarrollo, a veces con un intervalo que va desde la expresión en estadios embrionarios para la calretinina hasta los estadios juveniles en el caso de la parvalbúmina. Sin embargo, en regiones como el metencéfalo, regiones específicas del mielencéfalo, y en el ganglio vestibuloacústico del Sistema Nervioso Periférico, los patrones de inmunorreactividad siguen un desarrollo paralelo que permite comparar ambos marcajes durante la ontogenia.

En el metencéfalo, las células de Purkinje maduran y se sitúan en una monocapa previamente a que finalice su división y migración en sentido medial-lateral de las células grano (Pouwels, 1978b). En nuestro estudio hemos observado que la inmunorreactividad para parvalbúmina en las células de Purkinje aparece seis días después de la eclosión, tiempo después de que éstas se hayan diferenciado y alcanzado su posición definitiva (Pouwels, 1978b). Las células grano son inmunorreactivas para calretinina en el estadio de eclosión dentro de las regiones laterales del cerebelo. Estas células migran desde regiones centrales hasta las regiones laterales, en las que detienen su migración y culminan su diferenciación (Pouwels, 1978b). A la capa de las células de Purkinje llegan fibras inmunorreactivas para calretinina en el estadio de eclosión, que se localizan en regiones laterales, y a lo largo del desarrollo se van dirigiendo a regiones mediales, siguiendo el mismo gradiente de maduración latero-medial que el cerebelo (Pouwels, 1978b). Por su 
localización dentro de la laminación cerebelar las hemos identificado como fibras trepadoras, que procedentes de la oliva (también inmunorreactiva para calretinina desde el estadio de eclosión), inervan a las dendritas de las células de Purkinje, modulando su actividad (Finger, 1983). El otro tipo celular inmunorreactivo para calretinina lo forman células fusiformes con dendritas de orientación horizontal, de características muy similares a las células de Lugaro, descritas como inmunorreactivas para calretinina en mamíferos y aves (Rogers, 1989a).

Al igual que ocurre en el metencéfalo, podemos encontrar una complementariedad en los patrones de inmunorreactividad para calretinina y parvalbúmina en el circuito que forman los núcleos vestibulares y las células de Mauthner (Retzlaff, 1957). Las células de Mauthner son positivas para parvalbúmina a partir de los seis meses, aunque estas células están en el grupo de las primeras neuronas que se forman durante el desarrollo embrionario en el encéfalo de teleósteos (Leghissa, 1942), pero son negativas para calretinina. Además, están inervadas por aferencias procedentes tanto de las células ganglionares vestibuloacústicas (Meredith y Butler, 1983; Zottoli y cols., 1995) como de los núcleos vestibulares (Triller y Korn, 1978), regiones que son inmunorreactivas para ambas proteínas desde estadios tempranos del desarrollo. En este sentido, hemos encontrado campos terminales inmunorreactivos para ambas proteínas sobre las células de Mauthner desde el estadio de 15 días posteclosión.

Además de las aferencias a las células de Mauthner, desde los núcleos vestibulares se desarrollan proyecciones que se disponen ipsilateralmente por el tracto vestibuloespinal y se dirigen hacia las neuronas medulares (Highstein y cols., 1992), y contralateralmente por el fascículo longitudinal medial hacia los núcleos motores mesencefálicos (Jansen y Enger, 1996a). En nuestro estudio hemos encontrado fibras inmunorreactivas para calretinina y parvalbúmina que discurren por estas vías desde los estadios iniciales del desarrollo posteclosión, así como campos terminales 
positivos sobre motoneuronas medulares y sobre el núcleo del fascículo longitudinal medial, el núcleo del nervio troclear y el núcleo del nervio oculomotor.

En el Sistema Nervioso Periférico, dentro del ganglio vestibular, la inmunorreactividad para calretinina aparece en el mismo tipo celular, las células ganglionares, aunque con un retraso de $50^{\circ}$-día respecto a la parvalbúmina, siendo probable un alto grado de colocalización en este tipo celular a lo largo del desarrollo. Durante la ontogenia se produjo un aumento gradual en el número de células inmunorreactivas para ambas proteínas. Las células ganglionares reciben estimulación de las regiones sensoriales vestibuloauditivas: sáculo, utrículo, lagena, la mácula neglecta y las crestas de los canales semicirculares (Becerra, 1989). Además, envían proyecciones a las células de Mauthner (Meredith y Butler, 1983) y a los núcleos del área octavolateral (McCormick y Braford, 1993), regiones en las que hemos encontrado campos terminales inmunorreactivos para calretinina y para parvalbúmina a lo largo del desarrollo. 


\section{INMUNORREACTIVIDAD PARA PROTEÍNAS LIGANTES DE CALCIO EN EL SISTEMA NERVIOSO DE PECES TELEÓSTEOS}

Son escasos los estudios realizados sobre la distribución de proteínas ligantes de calcio en el Sistema Nervioso de teleósteos. En nuestra revisión bibliográfica solamente hemos encontrado un trabajo en el que se describe la distribución de calbindina D-28k a lo largo del desarrollo de la retina de la trucha común, Salmo trutta fario (Vecino y cols., 1993). Sin embargo, hay diversos estudios acerca de la distribución de calretinina, calbindina D-28k y parvalbúmina en regiones concretas del Sistema Nervioso de teleósteos adultos. A continuación compararemos los resultados obtenidos en la presente Memoria de Tesis Doctoral con los obtenidos por otros autores en trabajos previos.

\section{Distribución de calbindina D-28k}

Se ha detectado inmunocitoquímicamente la presencia de calbindina D-28k en teleósteos adultos en las motoneuronas de la médula espinal (Denizot y cols., 1988; Djebar y cols., 1995), en el techo óptico (Miguel-Hidalgo y cols., 1991), en los núcleos electrosensoriales (Maler y cols., 1984; Losier y Matsubara, 1990) y en el sistema vestibular (Dechesne y cols., 1988; Presson, 1994) de teleósteos adultos, así como en la retina durante el desarrollo (Vecino y cols., 1993). Todos estos trabajos previos indican la presencia de calbindina D-28k en elementos neuronales. Por el contrario, como hemos comentado anteriormente, nosotros encontramos inmunorreactividad para calbindina D-28k en células de glia radial, células satélite perineuronales, así como en células y prolongaciones ependimales y astrocitarias en los estadios juveniles y adulto. Además, en estudios previos realizados por nuestro grupo de investigación en encéfalo (Velasco, 1992), médula espinal, (López, 1996) y retina (Weruaga, 1991) de trucha arco iris adulta se ha detectado la presencia de 
inmunomarcaje con el anticuerpo monoclonal McAB 300 en los mismos tipos de células gliales descritos por nosotros.

Esta divergencia en los resultados obtenidos se debe, como hemos indicado anteriormente, a las diferentes características de los anticuerpos empleados. En este sentido, los resultados descritos para calbindina D-28k por Vecino y cols. (1993) en su estudio durante la ontogenia de la retina de la trucha común, Salmo trutta fario, se asemejan en gran medida tanto en los tipos celulares, como en su secuencia de aparición, con los observados por nosotros en la trucha arco iris utilizando anticuerpos específicos contra calretinina. En el techo óptico de la tenca Tinca tinca, tras emplear anticuerpos policlonales contra calbindina D-28k (Miguel-Hidalgo y cols., 1991) y contra calretinina (Arévalo y cols., 1995b), también se observa una gran similitud entre los dos patrones de inmunotinción, lo que indicaría que se están originando problemas de reactividad cruzada.

\section{Distribución de calretinina}

Los datos existentes sobre la distribución de esta proteína en el Sistema Nervioso de teleósteos son escasos. Se ha descrito inmunorreactividad para calretinina en el techo óptico de la tenca Tinca tinca en estado adulto (Arévalo y cols., 1995b), siendo similar el patrón descrito en este estudio con el observado por nosotros en los ejemplares adultos de trucha arco iris. Así, en ambas especies son inmunorreactivos los axones retinotectales de los estratos óptico y fibroso y gris superficial, así como neuronas inmunorreactivas en los estratos periventricular, blanco central y gris central. Sin embargo, en la trucha arco iris hemos visto neuronas inmunorreactivas para calretinina en el estrato fibroso y gris superficial y en el estrato óptico, que no aparecen en el techo óptico de la tenca. Además, en el estrato marginal observamos expresión transitoria de calretinina hasta el año de edad, desapareciendo en los adultos. Se ha descrito tambien la distribución de calretinina en la médula 
espinal de la trucha arco iris (López, 1996). Al igual que en el presente trabajo, la inmunorreactividad para calretinina en la médula espinal se encuentra en motoneuronas, neuronas supramedulares de los corpúsculos epiteliales, fibras de la sustancia gris y axones de los tractos de la médula espinal.

\section{Distribución de parvalbúmina}

La inmunorreactividad para parvalbúmina ha sido estudiada en regiones concretas del Sistema Nervioso adulto en diferentes especies de teleósteos. En el telencéfalo, las áreas dorsodorsal, dorsolateral y dorsocentral, así como las áreas ventroventral, ventrosupracomisural y ventrodorsal poseen neuronas inmunorreactivas para parvalbúmina en la tenca, Tinca tinca (Ibáñez, 1990; Briñón y cols., 1994). En la trucha arco iris, el marcaje es menos extenso, ya que no hemos encontrado inmunorreactividad para parvalbúmina en el área dorsocentral del telencéfalo, si bien es coincidente en el área ventral. En el cerebelo, nuestros resultados son similares a los descritos hasta ahora en la trucha arco iris y en la tenca adultas (Alonso y cols., 1992). En las dos especies, las células de Purkinje del cerebelo son positivas a parvalbúmina. Por el contrario, en la retina, nuestros resultados son diferentes a los descritos previamente en el carpín dorado Carassius auratus (Sanna y cols., 1993a). No hemos observado células ganglionares ni amacrinas inmunorreactivas para parvalbúmina, que sí han sido descritas en la retina del carpín dorado (Sanna y cols., 1993a). En la medula espinal, al igual que en el caso de la calretinina y la calbindina D-28k, el marcaje para parvalbúmina es similar al que observó López (1996) en la trucha arco iris. Dicho marcaje aparece en oligodendrocitos interfascículares, ependimocitos, tractos fibrilares ascendentes, descendentes y comisurales, y en motoneuronas. Dentro del Sistema Nervioso Periférico, en el ganglio vestibuloacústico encontramos células ganglionares positivas 
a parvalbúmina. Las mismás células han sido descritas como inmunorreactivas para parvalbúmina en el pez cíclido Astronotus ocellatus (Presson, 1994). 


\section{DISTRIBUCIÓN DE PROTEÍNAS LIGANTES DE CALCIO EN OTROS VERTEBRADOS}

La secuencia de aparición de las tres proteínas ligantes de calcio ha sido observada dentro del Sistema Nervioso Central de mamíferos (Enderlin y cols., 1987; Solbach y Celio, 1991; Andressen y cols., 1993) en el mismo orden que nosotros hemos visto en la trucha arco iris. La primera en expresarse es la calretinina, después la calbindina D-28k y por último la parvalbúmina. Sin embargo, en el Sistema Nervioso Periférico de la trucha arco iris, la aparición de parvalbúmina es más precoz que la de las otras dos proteínas, circunstancia que también se ha encontrado en mamíferos (Zhang y cols., 1990; Enderlin y cols., 1987, Solbach y Celio, 1991; Dechesne y cols., 1994). Existen numerosos trabajos sobre la expresión de las tres proteínas ligantes de calcio objeto de nuestro estudio en el Sistema Nervioso de mamíferos adultos (Celio, 1990; Arai y cols., 1991; Jacobowitz y Winsky, 1991; Résibois y Rogers, 1992; Rogers y Résibois, 1992) y durante el desarrollo (Enderlin y cols., 1987; Solbach y Celio, 1991). Sin embargo, los estudios acerca de su expresión durante la ontogenia del Sistema Nervioso en otros vertebrados son escasos, existiendo sólo datos en la corteza cerebral de la lagartija Podarcis hispanica (Martínez-Guijarro y cols., 1994), y en el cerebelo y la retina del pollo (Sanna y cols., 1992, Bastianelli y Pochet, 1993).

\section{Distribución de calbindina D-28k}

En los mamíferos se han realizado numerosos estudios acerca de la distribución de calbindina D-28k a lo largo del desarrollo en diferentes regiones encefálicas: corteza cerebral (Hendrickson y cols., 1991; Hogan y Berman, 1993), hipocampo (Goodman y cols., 1993), cerebelo (Shamley y cols., 1992) complejo olivar superior (Friauf, 1993), núcleos cocleares (Friauf, 1994), médula espinal (Antal y Polgár, 
1993), y también en el conjunto del encéfalo de la oveja (McDonald y cols., 1995) y de la rata (Enderlin y cols., 1987). También se ha estudiado exhaustivamente su distribución en el Sistema Nervioso de la rata adulta (Celio, 1990). En todos estos estudios, el marcaje ha aparecido en subpoblaciones neuronales específicas. Al igual que sucede en la trucha arco iris, en las paredes ventriculares del cerebro de rata adulta aparecen células ependimales inmunorreactivas para calbindina D-28k (Feldman y Christakos, 1983; García-Segura y cols., 1984; Celio, 1990). También en el estriado del ratón se ha descrito la expresión transitoria de calbindina D-28k en células de glía radial durante los últimos días de desarrollo embrionario (Liu y Graybiel, 1992). Dicha región del encéfalo de mamíferos es homóloga al área dorsomedial telencefálica de teleósteos (Butler y Hodos, 1996), en la que nosotros encontramos glia radial positiva a calbindina D-28k durante el desarrollo.

\section{Distribución de parvalbúmina}

El patrón de inmunotinción observado para parvalbúmina en el Sistema Nervioso de la trucha arco iris es mucho más restringido que el que se observa en mamíferos. Además, el inmunomarcaje aparece en estadios tempranos (mayoritariamente prenatales) en mamíferos, mientras que lo hace en estadios tardíos (en numerosas ocasiones juveniles) en la trucha arco iris. A continuación compararemos las características del marcaje para parvalbúmina en las diferentes regiones del Sistema Nervioso de la trucha arco iris con los resultados descritos en otras especies de vertebrados.

\section{$\underline{\text { Telencéfalo }}$}

Dentro del telencéfalo de la trucha arco iris podemos distinguir dos regiones, los bulbos olfatorios y los hemisferios telencefálicos. La estructura del bulbo olfatorio es común a todos los vertebrados (Allison, 1953), aunque existen variaciones entre los 
teleósteos y los tetrápodos, tanto en los tipos neuronales como en los patrones de conectividad (Kosaka y Hama, 1982; Alonso, 1987). En el bulbo olfatorio de la trucha arco iris hemos descrito interneuronas positivas a parvalbúmina localizadas en el límite entre los estratos glomerular y plexiforme, y en el de los granos, pero su aparición durante el desarrollo es muy tardía, en el estadio juvenil de un año. En el bulbo olfatorio de la rata, la expresión de parvalbúmina, comienza siete días después del nacimiento (Kosaka y cols., 1994b), y el número de células inmunorreactivas va aumentando gradualmente hasta alcanzar el patrón adulto, en el que diversos tipos de interneuronas localizadas en la capa plexiforme externa expresan parvalbúmina (Celio, 1990; Kosaka y cols., 1994a).

En los mamíferos, los hemisferios telencefálicos son el centro de integración encefálico más complejo (Delmas, 1976). En teleósteos se encuentran menos desarrollados y están asociados principalmente con la función olfatoria (Romer, 1970), habiéndose establecido una serie de homologías de las diferentes áreas telencefálicas de teleósteos con diversas regiones del telencéfalo de los mamíferos (Vanegas y Ebbesson, 1976; Northcutt y Braford, 1980; Butler y Hodos, 1996). En la corteza cerebral de mamíferos la expresión de parvalbúmina se inicia en la primera semana de vida postnatal, en la rata (Solbach y Celio, 1991; Sánchez y cols., 1992; Alcántara y cols., 1993; De Lecea y cols., 1995), en el ratón (Del Río y cols., 1994) y en el gato (Alcántara y Ferrer, 1994; Hogan y Berman, 1994). Por el contrario, en los primates la expresión es más temprana, puesto que se inicia ya en estadios fetales (Hendrickson y cols., 1991; Verney y Derer, 1995; Yan y cols., 1995; Cao y cols., 1996). En la corteza de la lagartija Podarcis hispanica el número de células inmunorreactivas para parvalbúmina aumenta progresivamente desde el nacimiento hasta el estado adulto (Martínez-Guijarro y cols., 1994). En la región de teleósteos homóloga a la corteza cerebral de otros vertebrados, el área dorsodorsal del telencéfalo, la inmunorreactividad para parvalbúmina aparece en un estadio muy tardío, seis meses después de la eclosión. 
En la rata adulta, además del marcaje en la corteza cerebral, hay otras regiones en las que aparece inmunorreactividad para parvalbúmina (Celio, 1990). Así ocurre en el estriado, homólogo al área dorsomedial del telencéfalo, que presenta neuronas inmunorreactivas para parvalbúmina en la trucha arco iris. Además hay neuronas marcadas para parvalbúmina en la amígdala basolateral y en el complejo septal, cuyas regiones homólogas en teleósteos (el área ventrosupracomisural, y las áreas ventrodorsal y ventroventral, respectivamente) también poseen inmunorreactividad para parvalbúmina en la trucha arco iris.

\section{Diencéfalo}

El diencéfalo es la región encefálica de teleósteos en la que se ha descrito mayor variabilidad en su constitución citoarquitectónica, y la nomenclatura de los núcleos no es homogénea entre los diferentes autores. Además, las homologías con el diencéfalo de tetrápodos son difíciles de establecer. Así, el tubérculo posterior es casi inexistente en los mamíferos, y los núcleos pretectales se encuentran reducidos en gran medida (Butler y Hodos, 1996).

En el diencéfalo de la trucha el marcaje para parvalbúmina es restringido y aparece después de la eclosión. Sin embargo, en los mamiferos es más abundante y más temprano en su aparición, detectándose ya en estadios embrionarios en algunos núcleos (Solbach y Celio, 1991).

Dentro del pretectum de la trucha arco iris, hemos observado marcaje en el núcleo pretectal y en el núcleo geniculado lateral, pero sólo en el estadio adulto, mientras que en la rata el marcaje para parvalbúmina en el área pretectal aparece en el día embrionario 21 (Solbach y Celio, 1991).

No hemos observado células inmunorreactivas para parvalbúmina en ningún núcleo talámico de la trucha arco iris. En el tálamo de la rata se ha descrito la aparición de células inmunorreactivas para parvalbúmina dentro del núcleo reticular 
talámico en el día embrionario 20 (Solbach y Celio, 1991), aumentando progresivamente el número de elementos positivos durante la primera semana de vida postnatal (Frassoni y cols., 1991, Mitrofanis, 1992). También dentro del tálamo, en la rata adulta aparece inmunorreactividad a parvalbúmina en los núcleos paratenial y geniculado lateral (Celio, 1990).

El epitálamo y el área preóptica de la trucha arco iris no poseen células inmunorreactivas para parvalbúmina en ninguna de sus divisiones. En el resto del diencéfalo, aparecen células marcadas únicamente en el núcleo glomeruloso del tubérculo posterior y en el núcleo del fascículo longitudinal medial del sinencéfalo. Sin embargo, en la rata adulta, el marcaje para parvalbúmina es muy abundante: así, además de las zonas talamicas y pretectales anteriormente indicadas, se observan algunas neuronas marcadas en la habénula epitalámica, núcleo paraventricular, área preóptica lateral, hipotálamo lateral y en los núcleos mamilares (Celio, 1990).

En la retina de la rata aparecen células amacrinas y ganglionares inmunorreactivas para parvalbúmina, así como algunos axones inmunorreactivos en el nervio, quiasma y tracto óptico (Celio, 1990). Por el contrario, nosotros no hemos observado inmunorreactividad para esta proteína en la retina de la trucha arco iris, ni en sus conexiones con el techo óptico mesencefálico.

\section{Mesencéfalo}

Existen homologías claras entre las diferentes regiones mesencefálicas de teleósteos y mamíferos. Así, los homólogos del techo óptico y el torus semicircularis de teleósteos en el encéfalo de mamíferos son el colículo superior e inferior, respectivamente (Butler y Hodos, 1996). En la trucha arco iris hemos observado células inmunorreactivas a parvalbúmina en diferentes estratos del techo óptico, pero sólo en animales de un año de edad y en adultos. Durante el desarrollo de la rata, se observan células en el colículo superior desde el día embrionario 21 (Solbach y Celio, 1991), y al alcanzar la edad adulta aparecen fibras inmunorreactivas para 
parvalbúmina, así como células bipolares inmunorreactivas en la capa del nervio óptico (Celio, 1990). En el torus semicircularis de la trucha arco iris, aparecen células inmunorreactivas a partir del año de edad. Sin embargo, en su homólogo en la rata, el colículo inferior, las primeras neuronas positivas a parvalbúmina se observan a la edad embrionaria de 21 días (Solbach y Celio, 1991).

En otras regiones mesencefálicas, como el núcleo oculomotor y el núcleo troclear, aparece inmunorreactividad para parvalbúmina tanto en la trucha arco iris como en la rata, si bien en la rata su expresión comienza en estadios embrionarios tempranos (Solbach y Celio, 1991), y en la trucha arco iris en individuos juveniles.

Otros núcleos mesencefálicos presentan inmunorreactividad en la rata pero no en la trucha, como el núcleo rojo y diversos núcleos tegmentales (Celio, 1990). El núcleo lateral de la válvula, estrechamente relacionado con el cerebelo en teleósteos y que no presenta homólogo en mamíferos (Butler y Hodos, 1996), presenta inmunorreactividad para parvalbúmina en la trucha arco iris.

\section{$\underline{\text { Metencéfalo }}$}

Hemos observado marcaje para parvalbúmina por primera vez dentro del cerebelo en las células de Purkinje en el estadio de 6 días después de la eclosión, alcanzándose el patrón de distribución definitivo a los 21 días despues de la eclosión. Sin embargo, en el metencéfalo de la rata la expresión de parvalbúmina en el cerebelo comienza durante el desarrollo embrionario en las células de Purkinje (Solbach y Celio, 1991), y cuatro días después del nacimiento todas ellas son inmunorreactivas para parvalbúmina, y se disponen en una monocapa. En el cerebelo humano, la inmunorreactividad para parvalbúmina se observa en la semana 16 de gestación en células de Purkinje (Yu y cols., 1996), aumentando la intensidad de inmunotinción hasta la semana 28, en la que puede observarse un elaborado árbol de dendritas inmunorreactivas para parvalbúmina en las células de Purkinje. 
Las células de Purkinje son muy variables en la morfología de su soma y en su patrón de ramificación dendrítica entre los distintos grupos de vertebrados. Además, en los teleósteos no son las células que envían proyecciones fuera del cerebelo, sino que contactan con las células euridendroides situadas por debajo de las células de Purkinje (Finger, 1983). Las células euridendroides son las que envían directamente sus axones a regiones tegmentales, a los núcleos vestibulares y a la médula espinal, no existiendo un contacto en núcleos cerebelosos profundos similar al descrito en otros vertebrados (Finger, 1983; Butler y Hodos, 1996). Si bien la organización citoarquitectónica de la vía es diferente, parece estar conservada en cuanto a su patrón de inmunotinción para parvalbúmina. Las células euridendroides, negativas para parvalbúmina están inervadas por los axones de Purkinje parvalbúmina-positivos. En los mamíferos, la función de las células euridendroides la cumplen las neuronas de los núcleos cerebelosos profundos, que no expresan parvalbúmina y también reciben axones de células de Purkinje positivos a parvalbúmina (Celio, 1990).

En el cerebelo de rata y en el humano son también inmunorreactivas para esta proteína las células estrelladas y las células en cesto (Celio, 1990; Yu y cols., 1996). Aunque estos tipos neuronales han sido descritos previamente en el metencéfalo de teleósteos (Finger, 1983; Pouwels, 1978a,b,c,d), en la trucha arco iris son negativos para parvalbúmina.

\section{$\underline{\text { Mielencéfalo }}$}

Dentro del mielencéfalo, la inmunorreactividad para parvalbúmina en los núcleos de los pares craneales aparece tardíamente en el Sistema Nervioso Central de teleósteos, en animales juveniles de un año y en los adultos. En cambio, en los mamíferos estos núcleos demuestran inmunorreactividad para parvalbúmina en estadios prenatales. Así, aparecen neuronas marcadas de los núcleos de los nervios oculomotor, troclear y abducens en el estadio embrionario 15, y en el núcleo del nervio trigémino en el día embrionario 19 (Solbach y Celio, 1991). En la formación 
reticular de la trucha arco iris las primeras neuronas inmunorreactivas se observan a los tres meses de edad. En la rata se observan interneuronas dispersas por esta región en el día embrionario 19 (Solbach y Celio, 1991).

En la trucha arco iris, las primeras neuronas inmunorreactivas que aparecen en el Sistema Nervioso Central son las que se sitúan en el área octavolateral, a los seis días después de la eclosión. En la rata, los núcleos vestibulares y cocleares son los homólogos de los del área octavolateral de teleósteos, y las primeras células inmunorreactivas que se observan en el núcleo coclear ventral aparecen el día embrionario 21 (Morris y cols., 1988; Solbach y Celio, 1991). En la rata adulta se observan neuronas inmunorreactivas para parvalbúmina en el núcleo vestibular medial (Celio, 1990).

Todos los núcleos de los nervios craneales situados en el mielencéfalo poseen inmunorreactividad para parvalbúmina en la trucha arco iris. En la rata aparecen teñidas las neuronas del núcleo del nervio trigémino, el núcleo del nervio vago y el núcleo del nervio hipogloso (Celio, 1990), que no tiene homólogo en la trucha arco iris (Butler y Hodos, 1996). Las células de Mauthner, neuronas de gran tamaño que no aparecen en los mamíferos (Butler y Hodos, 1996), son positivas a parvalbúmina, al igual que el núcleo del fascículo solitario, que es negativo en la rata (Celio, 1990). Sin embargo, aparecen células inmunorreactivas para parvalbúmina en el núcleo olivar inferior de la rata (Celio, 1990), mientras que no hemos observado inmunorreactividad para parvalbúmina en la oliva de la trucha arco iris.

\section{Médula espinal}

Una característica común entre el marcaje para parvalbúmina en la rata (Celio, 1990; Ren y Ruda, 1994) y en la trucha arco iris es la presencia de inmunorreactividad en gran cantidad de fibras que discurren por tractos axonales ascendentes, descendentes y comisurales presentes en la médula espinal. En la rata se ha descrito la expresión transitoria de parvalbúmina en células de las astas dorsales 
desde el día embrionario 17 hasta el día embrionario 20 (Solbach y Celio, 1991), fenómeno que no se observa en la médula espinal de la trucha arco iris.

\section{$\underline{\text { Sistema Nervioso Periférico }}$}

Nuestros resultados muestran que el sistema vestibuloacústico es la primera región en la que se expresa parvalbúmina en la trucha arco iris. Aparecen células inmunorreactivas en el interior del ganglio en el estadio de $250^{\circ}$-día, y sus prolongaciones inmunomarcadas se observan dentro de los núcleos vestibulares mielencefálicos a los dos días después de la eclosión. En la rata, tambien el sistema vestibuloacústico es muy temprano en la expresión de dicha proteína (Morris y cols., 1988; Solbach y Celio, 1991). En el día embrionario 14 aparecen las primeras neuronas marcadas en el ganglio vestibular, y algunas fibras inmunorreactivas de la raíz del ganglio penetran en el mielencéfalo. La expresión en el ganglio coclear es algo más tardía, comenzando en el día embrionario 17, observándose terminales marcados dentro de la oliva superior en el día embrionario 19 (Morris y cols., 1988; Solbach y Celio, 1991).

\section{Marcaje en células gliales}

En los ejemplares de trucha arco iris de un año y adultos observamos marcaje en ependimocitos del telencéfalo y de la médula espinal. También en la rata, se expresa parvalbúmina de forma transitoria, desde el estadio embrionario 15 hasta el nacimiento, en tanicitos y células ependimales dispersas por los ventrículos telencefálicos y el tercer ventrículo (Solbach y Celio, 1991). En estudios realizados en ratas adultas in vivo (Celio, 1990) o in vitro (Crespo y cols., 1995) se ha descrito la presencia de inmunorreactividad para parvalbúmina en ependimocitos y astrocitos de mamíferos.

\section{Distribución de calretinina}


Como hemos hecho para la parvalbúmina, compararemos nuestros resultados sobre la distribución de calretinina en el encéfalo de la trucha arco iris con datos previos en otros vertebrados. En general, existe un mayor grado de coincidencia en la evolución del marcaje para calretinina entre teleósteos y otros vetebrados, que el observado con parvalbúmina. Sin embargo, hay regiones que presentan diferencias en el marcaje entre los distintos grupos, y es difícil llevar a cabo una correlacion temporal durante el desarrollo. Por ello, el uso del marcaje para calretinina como herramienta para establecer homologías entre áreas del Sistema Nervioso debe circunscribirse a zonas concretas, y confirmar los resultados con los obtenidos mediante estudios morfólogicos o de distribución de otros marcadores específicos.

Los trabajos sobre la distribución de calretinina a lo largo del desarrollo ontogenético del Sistema Nervioso de mamíferos se restringen a zonas concretas, no existiendo un trabajo que estudie en su totalidad el mismo durante los diferentes estadios. En cambio, sí existen estudios detallados de la distribución de calretinina en el conjunto del Sistema Nervioso en el adulto (Arai y cols., 1991; Jacobowitz y Winsky, 1991; Résibois y Rogers, 1992).

\section{Telencéfalo}

En nuestro estudio hemos detectado la presencia de calretinina en estadios embrionarios tempranos en los receptores olfatorios y en sus axones que conectan con el bulbo olfatorio. En los receptores y fibras olfatorias de la rata se observa inmunorreactividad para calretinina desde los primeros días del desarrollo postnatal (Bastianelli y Pochet, 1995; Bastianelli y cols., 1995a), alcanzándose el patrón adulto 20 días después del nacimiento. En la rata, tanto las células mitrales como diferentes tipos de interneuronas (periglomerulares y granos) son inmunorreactivas para calretinina (Wouterlood y Härtig, 1995). Sin embargo, en el bulbo olfatorio de la trucha arco iris sólo aparece inmunorreactividad en un tipo celular, los granos. En el sistema olfatorio accesorio de la rata aparecen marcadas para calretinina las 
aferencias vomeronasales (Bastianelli y cols., 1995a), interneuronas (células periglomerulares y granos) y células mitrales (Jacobowitz y Winsky, 1991). El sistema olfatorio accessorio se desarrolla como un sistema sensorial independiente en los tetrápodos (Allison, 1953), y por tanto no está desarrollado en la trucha arco iris.

En los hemisferios telencefálicos de la trucha arco iris la calretinina aparece ampliamente distribuida. Así, aparece marcaje en el área dorsolateral, región homóloga de la corteza cerebral de mamíferos (Northcutt y Braford, 1980). En esta región se ha descrito expresión transitoria de calretinina durante el desarrollo embrionario en las células de Cajal-Retzius tanto en roedores (Vogt-Weisenhorn y cols., 1994; Del Río y cols., 1995) como en primates (Fonseca y cols., 1995; Verney y Derer, 1995; Yan y cols., 1995). Sin embargo, en el área dorsolateral de la trucha arco iris el marcaje va aumentando gradualmente hasta alcanzar el patrón adulto, y en ningún caso hemos detectado la expresión transitoria de la proteína en dicha región.

Hemos observado también inmunorreactividad para calretinina en el área ventroventral y ventrosupracomisural del telencéfalo de la trucha arco iris. En las regiones homólogas del telencéfalo de la rata, septo medial y amígdala, respectivamente, también se ha descrito la presecia de células positivas a calretinina (Jacobowitz y Winsky, 1991; Résibois y Rogers, 1992). En los núcleos caudado y putamen aparecen células inmunorreactivas en la rata adulta (Jacobowitz y Winsky, 1991; Résibois y Rogers, 1992). Dichos núcleos son homólogos al área dorsodorsal de la trucha arco iris (Northcutt y Braford, 1980), y al contrario de lo que sucede en otras áreas telencefálicas, en ellos no hemos observado marcaje.

\section{Diencéfalo}

En nuestra revisión bibliográfica no hemos encontrado datos sobre la expresión de calretinina a lo largo del desarrollo en el diencéfalo de la rata. Sin embargo, en el diencéfalo de la rata adulta el marcaje está muy extendido (Arai y cols., 1991; Jacobowitz y Winsky, 1991; Résibois y Rogers, 1992). La amplia distribución de 
calretinina en el diencéfalo, importante estación de relevo de vías sensoriales y motoras, así como directamente involucrado en el control neuroendocrino, es una característica compartida entre la rata y la trucha arco iris.

En la trucha arco iris, la inmunorreactividad para calretinina aparece ampliamente distribuida tanto en las regiones talámicas dorsales como en las ventrales, así como en diferentes núcleos del túber y la región periventricular hipotalámica. Igual sucede en la rata, donde aparecen neuronas inmunopositivas en núcleos talámicos como el periventricular, el reticular, el centromedial, el lateral posterior, el paraventricular y el subparafascicular (Jacobowitz y Winsky, 1991; Résibois y Rogers, 1992). En el hipotálamo de la rata todos los núcleos, excepto el paraventricular y el posterior mamilar, poseen células inmunorreactivas para calretinina (Jacobowitz y Winsky, 1991; Résibois y Rogers, 1992).

El marcaje también está ampliamente distribuido en el pretectum de la trucha arco iris, apareciendo neuronas inmunorreactivas en el área pretectal, núcleo geniculado lateral, núcleo pretectal y núcleo rotundo. Todos los núcleos del pretectum de la rata presentan también neuronas inmunorreactivas a calretinina (Jacobowitz y Winsky, 1991; Résibois y Rogers, 1992).

Una de las regiones en las que hemos observado expresión transitoria de calretinina en la trucha es la habénula. Dicha región no presenta células inmunorreactivas en el adulto; por el contrario, en la habénula de la rata sí aparece expresión de calretinina en el adulto (Jacobowitz y Winsky, 1991; Résibois y Rogers, 1992).

También se ha estudiado la distribución de calretinina durante el desarrollo postnatal en la retina de la rata (Bastianelli y cols., 1995b). La inmunorreactividad aparece desde el primer día del desarrollo postnatal en células ganglionares y en células amacrinas, de modo similar a lo que ocurre en la trucha arco iris. Además, se ha estudiado el patrón de inmunorreactividad para calretinina en la retina adulta de 
diferentes especies de vertebrados (Rogers, 1989b; Pasteels y cols., 1990). En todas las especies estudiadas se ha descrito inmunorreactividad en células bipolares, células amacrinas y células ganglionares. Los mismos tipos celulares son positivos para calretinina en la retina de la trucha arco iris.

\section{$\underline{\text { Mesencéfalo }}$}

Igual que en el diencéfalo, no existen estudios que describan la aparición y desarrollo de elementos inmunorreactivos para calretinina en el mesencéfalo de vertebrados amniotas. Sí se ha descrito el patrón de inmunorreactividad en el mesencéfalo de rata adulta (Arai y cols., 1991; Résibois y Rogers, 1992). En la trucha arco iris, los axones de las células ganglionares de la retina, a lo largo de su recorrido por el nervio, quiasma y tracto óptico hasta alcanzar el techo óptico, son positivas para calretinina. También son positivos en la rata en todo su recorrido hasta que llegan al colículo superior (Arai y cols., 1991; Résibois y Rogers, 1992). Se observaron además células inmunorreactivas en la capa del nervio óptico del colículo superior, de modo similar a lo que ocurre en diferentes estratos del techo óptico de la trucha arco iris. Por tanto, el marcaje para calretinina parece estar conservado en la vía visual. También aparece inmunorreactividad en el colículo inferior de la rata (Arai y cols., 1991; Résibois y Rogers, 1992), homólogo del torus semicircularis de la trucha arco iris en el que hemos descrito la presencia de células marcadas para calretinina.

En otras regiones mesencefálicas el marcaje es también similar en la trucha y en la rata. No aparece inmunorreactividad para calretinina en el núcleo troclear ni en el núcleo oculomotor, mientras que sí que aparece en el núcleo tegmental reticular (Résibois y Rogers, 1992). Por el contrario, el marcaje es diferente en otras zonas. En la rata adulta aparecen neuronas inmunorreactivas para calretinina en el núcleo interpeduncular (Résibois y Rogers, 1992), mientras que en la trucha arco iris aparecen transitoriamente durante el desarrollo, pero no se observan en el adulto. En 
el núcleo rojo no aparece inmunorreactividad en la rata (Résibois y Rogers, 1992), mientras que sí la hemos observado en la trucha arco iris.

\section{Metencéfalo}

La expresión de calretinina en el metencéfalo queda restringida al cerebelo, tanto en la trucha arco iris como en otras especies de vertebrados en las que se ha estudiado.

En el cerebelo del pollo, la calretinina se expresa de forma transitoria entre los estadios embrionarios 11 y 20 en granos y células de Golgi (Bastianelli y Pochet, 1993), mientras que en el pollo adulto la inmunorreactividad aparece en las células estrelladas y en cesto de la capa molecular, en las células de Lugaro y en las fibras musgosas y trepadoras (Rogers, 1989a). En el ratón, las células inmunorreactivas aparecen durante el desarrollo embrionario y se mantienen hasta el adulto (Abbott y Jacobowitz, 1995). En la rata adulta se observa inmunorreactividad en granos, en células de Lugaro y en las fibras musgosas (Rogers, 1989a; Résibois y Rogers, 1992). Los elementos positivos para calretinina en el cerebelo de la trucha aparecen en el momento de la eclosión, aumentando su tamaño e intensidad de tinción gradualmente hasta el estadio adulto. Tanto en el pollo como en la rata la expresión de calretinina en el cerebelo es más temprana, aparece en estadios embrionarios (Rogers, 1989a; Bastianelli y Pochet, 1993). Además, en el pollo aparece expresión transitoria de calretinina entre los estadios embrionarios 11 y 21, en granos y células de Golgi (Bastianelli y Pochet, 1993). En el cerebelo de la trucha arco iris no hemos encontrado células que expresen calretinina de forma transitoria. Los granos son positivos en el cerebelo de trucha arco iris y rata adultas (Rogers, 1989a; Résibois y Rogers, 1992). Sin embargo, en el pollo adulto sólo son positivas a calretinina las células estrelladas y en cesto de la capa molecular (Rogers, 1989a). En cuanto a las fibras, en el pollo son positivas las fibras musgosas y trepadoras (Rogers, 1989a), en 
rata sólo las musgosas (Résibois y Rogers, 1992), y en la trucha arco iris sólo las trepadoras.

El dato que más llama la atención es que en las tres especies las células de Lugaro son positivas a calretinina (Rogers, 1989a; Résibois y Rogers, 1992). Las células de Lugaro sólo se habían descrito hasta el momento en mamíferos (Butler y Hodos, 1996), pero su morfología ahusada y la orientación horizontal de sus dendritas en la trucha arco iris nos permite identificarlas como homólogas a las descritas por Rogers (1989a) como inmunorreactivas a calretinina en el cerebelo del pollo y la rata.

\section{$\underline{\text { Mielencéfalo }}$}

La expresión de calretinina en el mielencéfalo de la trucha es muy temprana, igual que sucede en el ratón, especie en la que se han descrito neuronas inmunomarcadas en la formación reticular en el estadio embrionario 10 (Abbott y Jacobowitz, 1995). No hemos encontrado datos sobre la expresión de calretinina durante la ontogenia en otros núcleos mielencefálicos ni en otras especies, pero sí existen estudios sobre su distribución en el cerebro de la rata adulta. El núcleo del trigémino, los núcleos cocleares y vestibulares, los núcleos del rafe, el núcleo del fascículo solitario, y los núcleos reticulares son positivos a calretinina tanto en la trucha arco iris como en la rata adultas (Arai y cols., 1991; Résibois y Rogers, 1992). Sin embargo, en el mielencéfalo de truchas adultas hemos observado inmunorreactividad para calretinina en el núcleo del nervio abducens y en el núcleo del nervio facial, que son negativos en la rata (Arai y cols., 1991; Rogers y Résibois, 1992). En la rata, las células de la oliva inferior son negativas a calretinina, y se encuentran rodeadas por neuropilo positivo (Résibois y Rogers, 1992). En cambio, en la trucha arco iris, además del neuropilo positivo a calretinina, las células de la oliva presentan calretinina.

\section{Médula espinal}


En la trucha arco iris, distintos tipos neuronales presentes en la médula espinal de teleósteos presentan inmunorreactividad para calretinina, así como fibras inmunorreactivas de diferentes calibres que discurren por los tractos medulares, y otras que forman plexos y campos terminales en la sustancia gris de la médula. El mismo tipo de marcaje, tanto en neuronas como en las fibras nerviosas ha sido descrito en la rata adulta (Résibois y Rogers, 1992; Ren y Ruda, 1994).

\section{$\underline{\text { Sistema Nervioso Periférico }}$}

Se ha descrito la expresión de calretinina a lo largo del desarrollo en los ganglios vestibular y coclear del ratón (Dechesne y cols., 1994). Las células ganglionares comienzan a expresar calretinina el día embrionario 19, y aumenta su número a lo largo del desarrollo hasta llegar al día postnatal 14, en el que el marcaje es similar al que aparece en el adulto. El mismo patrón se ha descrito en la rata adulta (Demêmes y cols., 1992). En la trucha arco iris la inmunorreactividad se observa por primera vez en estadios embrionarios, y al igual que sucede en el ratón, se produce un aumento gradual en el número de elementos inmunorreactivos hasta alcanzar el estado adulto. 


\section{DISTRIBUCIÓN DE NEUROTRANSMISORES Y SUSTANCIAS NEUROACTIVAS EN EL SISTEMA NERVIOSO DE TELEÓSTEOS}

Los estudios que describen la distribución de neurotransmisores y sustancias neuroactivas durante el desarrollo del Sistema Nervioso de teleósteos son escasos, conociéndose solamente datos sobre catecolaminas (Ekström y cols., 1992; Manso y cols., 1993), serotonina (Ekström y cols., 1985; Bolliet y Ali, 1992; Ekström, 1994), hormona liberadora de gonadotropina (Chiba y cols., 1994; Parhar y cols., 1995) ácido gamma-aminobutírico (Ekström y Ohlin, 1995), somatostatina (Becerra y cols., 1995) y sustancia P (Vecino y Sharma, 1992). Otras sustancias neuroactivas no se han estudiado a lo largo de la ontogenia, pero sí en el Sistema Nervioso de los animales adultos. Así se conoce la distribución de sustancias como encefalinas (Vecino y cols., 1992), neuropéptido Y (Pickavance y cols., 1992; Subhedar y cols., 1996), y sintasa del óxido nítrico (Holmqvist y cols., 1994; Östholm y cols., 1994; Arévalo y cols., 1995a; Turner y Moroz, 1995; Anken y Rahmann, 1996), entre otras. Estos trabajos han sido realizados en especies muy diversas, y la mayoría de las sustancias no han sido estudiadas en la trucha arco iris, por lo que no podemos realizar una comparación directa con nuestros resultados sobre la distribución de proteínas ligantes de calcio. Analizando los trabajos previos sobre la distribución de diversas sustancias en el Sistema Nervioso de teleósteos tanto durante la ontogenia como en el estado adulto, la conclusión a la que llegamos es que no existe en ningún caso una correspondencia total con los resultados obtenidos para proteínas ligantes de calcio en la trucha arco iris. Aunque en determinadas regiones se produce una colocalización zonal, sería necesario realizar dobles marcajes para demostrar la posible colocalización a nivel celular. 


\section{Catecolaminas}

Se ha estudiado la evolución durante el desarrollo y el patrón adulto de marcaje para tiroxina hidroxilasa, dopamina- $\beta$-hidroxilasa y dopamina en diferentes especies de teleósteos, como la trucha arco iris (Alonso y cols., 1989a), la trucha común Salmo trutta fario (Manso y cols., 1993; Becerra y cols., 1994a), el espinoso Gasterosteus aculeatus (Ekström y cols., 1990,1992) y en el mormírido Gnathonemus petersii (Meek y Joosten, 1993).

El marcaje para tirosina hidroxilasa aparece en estadios embrionarios, como en el caso de la calretinina. La inmunorreactividad para dopamina- $\beta$-hidroxilasa y dopamina aparece en los mismos tipos neuronales que la tirosina hidroxilasa, aunque con un cierto retraso temporal (Ekström y cols., 1992). Los primeros elementos inmunorreactivos para tirosina hidroxilasa aparecen durante el desarrollo embrionario en el núcleo posterior del túber, que es inmunorreactivo para calretinina durante el desarrollo embrionario, y en el núcleo del fascículo solitario, que es positivo para parvalbúmina y calretinina pocos días después de la eclosión. También se observa tirosina hidroxilasa en el locus coeruleus, que no presenta inmunorreactividad para proteínas ligantes de calcio a lo largo del desarrollo. Más tardíamente aparecen neuronas en las áreas ventrodorsal, ventroventral y ventrosupracomisural del telencéfalo, en granos del bulbo olfatorio, en los núcleos del área octavolateral, en los núcleos ventrales y dorsales del tálamo, en el núcleo pretectal, en el núcleo reticular inferior y en el núcleo del fascículo solitario. Todas estas regiones presentan inmunorreactividad para proteínas ligantes de calcio durante el desarrollo embrionario o en los primeros días tras la eclosión.

En la habénula se observó una expresión transitoria de tirosina hidroxilasa en estadios juveniles, estando el marcaje ausente de esta región en los adultos (Manso y 
cols., 1993). Este mismo fenómeno se ha observado en la inmunotinción para calretinina en la habénula de la trucha arco iris.

En la retina (Becerra y cols., 1994a), la inmunorreactividad para tirosina hidroxilasa aparece durante el desarrollo embrionario en células interplexiformes dispersas en la capa nuclear interna, que aparecen en primer lugar en las regiones de la retina periférica, haciéndose el marcaje extensivo a las zonas centrales a lo largo del desarrollo. El marcaje para calretinina observado en la retina de la trucha arco iris, además de aparecer en tipos neuronales diferentes (células ganglionares y amacrinas) sigue un patrón espacio-temporal de aparición inverso a lo largo del desarrollo. Los primeros elementos inmunorreactivos aparecen en la retina central durante el desarrollo embrionario, generalizándose el marcaje a la retina periférica a lo largo de la vida del animal.

\section{Serotonina}

La inmunorreactividad para serotonina aparece durante el desarrollo embrionario en los núcleos del rafe en el salvelino Salvelinus fontinalis (Bolliet y Ali, 1992) y en el espinoso Gasterosteus aculeatus (Ekström y cols., 1985; Ekström, 1994), núcleos que poseen calretinina en la trucha arco iris desde la eclosión. En esas dos especies, a lo largo del desarrollo se han observado además células positivas a serotonina en el área pretectal y en el núcleo del receso posterior, regiones que también presentan calretinina en la trucha arco iris. En los núcleos del rafe, se ha descrito una expresión transitoria de serotonina en las dos especies antes mencionadas, que desaparece en los animales adultos. Por el contrario, en el gimnoto Apteronotus leptorhynchus aparece serotonina en los núcleos del rafe en el adulto (Johnston y cols., 1990). No hemos encontrado expresión transitoria de ninguna de las proteínas ligantes de calcio estudiadas en los núcleos del rafe. 


\section{Hormona liberadora de gonadotropina}

La distribución de hormona liberadora de gonadotropina durante el desarrollo se ha descrito en varias especies de teleósteos: en dos salmones, Oncorhynchus nerka y O. keta (Chiba y cols., 1994; Parhar y cols., 1995), en el gurami enano Colisa lalia (Maejima y cols., 1994; Yamamoto y cols., 1995), en el carpín dorado Carassius auratus (Kim y cols., 1995), y en la anguila Anguilla anguilla (Montero y cols., 1994). Su distribución es muy restringida a lo largo del Sistema Nervioso. Las células positivas se originan primeramente en la placoda olfatoria y van migrando progresivamente a lo largo del desarrollo hacia el bulbo olfatorio, el área ventromedial telencefálica, el núcleo preóptico anterior y la base del ventrículo mesencefálico. Su patrón de aparición y migración no se corresponde con el que hemos detectado para las proteínas ligantes de calcio, aunque en esas mismas zonas encontramos expresión de calretinina y parvalbúmina. En animales adultos la hormona liberadora de gonadotropina aparece en el núcleo del fascículo longitudinal medial, que también presenta calretinina y parvalbúmina en la trucha arco iris adulta, pero en este caso su expresión comienza durante el desarrollo.

\section{Ácido gamma-aminobutírico}

Se ha estudiado la distribución de inmunorreactividad para ácido gammaaminobutírico durante el desarrollo del encéfalo del espinoso, Gasterosteus aculeatus (Ekström y Ohlin, 1995) y de la retina del pez cebra Brachydanio rerio (Sandell y cols., 1994), así como el patrón definitivo en el encéfalo adulto de la anguila Anguilla anguilla (Médina y cols., 1994). Las primeras estructuras en las que aparece ácido gamma-aminobutírico son la región preóptica y la médula espinal, regiones que 
expresan tempranamente calretinina en la trucha arco iris, así como el núcleo del fascículo longitudinal medial, que expresa calretinina y parvalbúmina más tardíamente (después de la eclosión). Posteriormente, aparecen células inmunorreactivas para ácido gamma-aminobutírico en las áreas dorsomedial y ventroventral del telencéfalo, y en los granos del bulbo olfatorio, en los que hay inmunorreactividad para calretinina y parvalbúmina en la trucha arco iris. La placoda olfatoria, que es una de las primeras regiones en expresar calretinina, muestra inmunorreactividad para ácido gamma-aminobutírico en la parte final del desarrollo embrionario. También aparecen grupos de neuronas inmunorreactivas para ácido gamma-aminobutírico en el hipotálamo (núcleos del receso lateral, receso posterior, posterior del túber y difuso del lóbulo inferior), en los núcleos ventrales y dorsales talámicos, así como en los núcleos geniculado lateral y pretectal del pretectum, regiones que también poseen neuronas inmunorreactivas para calretinina durante el desarrollo en la trucha arco iris.

Justo antes de la eclosión se observaron por primera vez neuronas inmunopositivas para ácido gamma-aminobutírico en el estrato periventricular del techo óptico, región en la que aparece inmunorreactividad para calretinina en un momento próximo a la eclosión, y en el cerebelo, region donde, en cambio, no se observó inmunorreactividad para proteínas ligantes de calcio hasta después de la eclosión. En el mielencéfalo son inmunorreactivos los núcleos vestibulares, del rafe, del nervio glosofaríngeo y del nervio vago, regiones que poseen células inmunorreactivas para proteínas ligantes de calcio, así como el locus coeruleus, que en cambio es negativo tanto para calretinina como para parvalbúmina.

En la retina, la inmunorreactividad para ácido gamma-amino butírico se observa por primera vez durante el desarrollo embrionario en células amacrinas de la capa nuclear interna, localizadas en las porciones centrales, que son positivas para calretinina durante el desarrollo embrionario de la trucha arco iris. Posteriormente, aparece inmunorreactividad para ácido gamma-aminobutírico en las células 
ganglionares, que se mantiene durante la vida embrionaria pero desaparece pocos días despues de la eclosión. En la trucha arco iris, la inmunorreactividad para calretinina aparece también más tarde en las células ganglionares que en las amacrinas, pero ambos tipos mantienen su inmunorreactividad durante todo el desarrollo.

\section{Somatostatina}

Se ha estudiado la evolución espacio-temporal del marcaje para somatostatina durante el desarrollo del encéfalo en la trucha común Salmo trutta fario (Becerra y cols., 1995), y su patrón de distribución en el carpín dorado adulto Carassius auratus (Pickavance y cols., 1992), en el pez cuchillo Eigenmania virescens (Zupanc y cols., 1991), y en el gimnoto Apteronotus leptorhynchus (Stroh y Zupanc, 1993),

Las primeras regiones que muestran inmunorreactividad para somatostatina son el núcleo lateral del túber del hipotálamo, región que presenta inmunorreactividad para calretinina durante el desarrollo embrionario de la trucha arco iris, así como las áreas ventrolateral y dorsomedial telencefálicas que son, sin embargo, muy tardías en la expresión de calretinina (se observa en estadios juveniles). Más tardíamente aparecen neuronas positivas a somatostatina en los núcleos preóptico periventricular, preóptico, y anterior periventricular del área preóptica, en el tálamo ventral y dorsal, así como en el núcleo difuso del torus lateralis, regiones que son positivas a calretinina en la trucha arco iris.

En el mesencéfalo aparecen células marcadas para somatostatina en el techo óptico y en el núcleo interpeduncular del tegmentum de forma transitoria, solamente en juveniles, no observándose en embriones, ni en alevines, ni en adultos. En estas regiones de la trucha arco iris también se ha descrito una expresión transitoria de calretinina, pero durante un periodo largo del desarrollo que ocupa los estadios de alevín y juveniles. 
En el metencéfalo es inmunorreactivo para somatostatina un nuevo tipo celular descrito por primera vez en teleósteos (Stroh y Zupanc, 1993), localizado entre los estratos molecular y granular del cerebelo, y con características morfológicas totalmente diferentes a las células de Purkinje positivas para parvalbúmina, a los granos y a las células de Lugaro positivas para calretinina en la trucha arco iris.

En el mielencéfalo, la inmunorreactividad para somatostatina aparece en el adulto en el gris central (inmunonegativo para proteínas ligantes de calcio), en los núcleos del nervio glosofaríngeo y del nervio vago (positivos sólo para parvalbúmina), así como en la formación reticular, en el núcleo del trigémino, y en el núcleo del fascículo solitario (inmunorreactivos tanto para parvalbúmina como para calretinina).

\section{Sustancia P}

La sustancia P se ha estudiado durante la ontogenia del carpín dorado, Carassius auratus (Vecino y Sharma, 1992), así como en el encéfalo adulto del gimnoto Apteronotus leptorhynchus (Weld y Maler, 1992). Los únicos elementos inmunorreactivos para sustancia P que aparecen antes de la eclosión se localizan en la región periventricular del telencéfalo, región que en la trucha arco iris posee neuronas positivas para calretinina durante el desarrollo embrionario, y para parvalbúmina en estadios juveniles y en el adulto. En otras regiones telencefálicas como el núcleo olfatoretinal y la región ventrocentral se ha descrito la presencia de inmunorreactividad para sustancia P, pero no para proteínas ligantes de calcio. Tras la eclosión se observan células inmunorreactivas para sustancia P en los núcleos del receso posterior, del receso lateral, posterior periventricular, posterior del túber del hipotálamo y, más tarde, en el torus semicircularis,el núcleo gustatorio secundario, y el núcleo del nervio vago. En todas estas regiones hemos detectado marcaje para proteínas ligantes de calcio en la trucha arco iris, pero el marcaje para calretinina en 
algunos de estos núcleos ya se observa en estadios embrionarios. También aparece marcaje para sustancia $\mathrm{P}$ en el núcleo ambiguo y en el área postrema, regiones en las que no hemos hallado neuronas inmunoteñidas para calretinina o para parvalbúmina. La habénula presenta inmunorreactividad para sustancia $\mathrm{P}$ en el adulto, mientras que muestra expresión transitoria de calretinina durante el desarrollo, pero es negativa en el adulto.

\section{Encefalinas}

Se ha descrito el patrón de inmunorreactividad para encefalinas en la trucha arco iris adulta (Vecino y cols., 1992). No existe una correlación general en el patrón de inmunorreactividad para encefalinas y proteínas ligantes de calcio, ya que estas últimas presentan una distribución mucho más extensa. Sin embargo, en algunas regiones, como el área ventral telencefálica, núcleos diencefálicos (núcleo ventromedial del tálamo, núcleo lateral del túber, núcleo del receso lateral y núcleo del receso posterior), torus semicircularis, núcleo rostral mesencefálico-tegmental, capa granular del cerebelo, y núcleo del fascículo solitario, que poseen células positivas para proteínas ligantes de calcio, podría existir una colocalización parcial.

\section{Neuropéptido $\mathbf{Y}$}

La distribución de neuropéptido Y se ha estudiado en el encéfalo del carpín dorado Carassius auratus (Pickavance y cols., 1992) y del pez cebra de agua salobre Fundulus heteroclitus (Subhedar y cols., 1996). Comparando la distribución de proteínas ligantes de calcio con la de neuropéptido Y, encontramos que podría existir un solapamiento de estas sustancias en algunas regiones del Sistema Nervioso de teleósteos. Son positivas para neuropéptido Y las áreas ventroventral, ventrolateral y dorsolateral telencefálicas, núcleo preóptico periventricular, núcleo preóptico, núcleo 
lateral del túber y núcleo dorsomedial del tálamo de ambas especies; además, en el carpín dorado son inmunorreactivos para neuropéptido Y los núcleos dorsolateral y ventromedial del tálamo, y el núcleo difuso del lóbulo inferior. Todas estas regiones son inmunorreactivas para proteínas ligantes de calcio en la trucha arco iris. Sin embargo, en regiones mesencéfalicas, metencéfalicas, mielencefálicas y de la médula espinal encontramos proteínas ligantes de calcio y nunca aparece neuropéptido Y. En otras zonas como el núcleo olfatoretinal, el núcleo entopeduncular y el área dorsocentral telencefálica del pez cebra de agua salobre, y el locus coeruleus del carpín dorado, se ha descrito la presencia de neuropéptido $\mathrm{Y}$, pero nosotros no encontramos ni calretinina ni parvalbúmina. En otro teleósteo, el salmón Salmo salar hay células inmunorreactivas para neuropéptido $\mathrm{Y}$ en el torus semicircularis y en el estrato periventricular del techo óptico (Vecino y Ekström, 1990), que en la trucha arco iris presentan marcaje tanto para calretinina como para parvalbúmina.

\section{Sintasa del óxido nítrico y NADPH-diaforasa}

La distribución de sintasa de óxido nítrico se ha estudiado en diversas especies de teleósteos tanto mediante técnicas inmunocitoquímicas, como con su marcador histoquímico, la NADPH-diaforasa. Así, existen trabajos en el carpín dorado Carassius auratus (Villani y Guarnieri, 1995a,b), tenca Tinca tinca (Arévalo y cols., 1995a), gimnoto Apteronotus leptorhynchus (Turner y Moroz, 1995), salmón Salmo salar (Holmqvist y cols., 1994; Östholm y cols., 1994), rodaballo Scophtalmus maximus (Jansen y Enger, 1996b) y en el pez de cola de sable Xiphophorus helleri (Anken y Rahmann, 1996). Esta enzima aparece en numerosos núcleos del Sistema Nervioso de teleósteos, siendo más abundantes las neuronas que la poseen en las áreas caudales del encéfalo y en la médula espinal que en las regiones encefálicas más rostrales (Arévalo y cols., 1995a). 
La distribución de proteínas ligantes de calcio es también muy amplia en el Sistema Nervioso de la trucha, y existen muchas regiones en las que los patrones se superponen con el observado para la sintasa del óxido nítrico, como son: las fibras olfatorias y los glomérulos del bulbo olfatorio, las áreas dorsomedial, ventroventral, ventrodorsal y ventrosupracomisural telencefálicas, el núcleo pretectal, el núcleo lateral del túber, el núcleo difuso del lóbulo inferior, el núcleo difuso del torus lateralis, el núcleo posterior periventricular, el núcleo glomeruloso, los cuerpos mamilares, los núcleos ventrales y dorsales del tálamo, el techo óptico, el torus semicircularis, los granos y células de Purkinje del cerebelo, los núcleos de los nervios troclear, oculomotor, abducens, facial, glosofaríngeo y vago, las células de Mauthner, los núcleos del área octavolateral, el núcleo del fascículo solitario, el rafe y la formación reticular. Sin embargo, los patrones no coinciden en su totalidad con los descritos para calretinina y para parvalbúmina en el Sistema Nervioso de la trucha arco iris adulta. Así encontramos sintasa del óxido nítrico en regiones que no presentan inmunorreactividad para proteínas ligantes de calcio, como las áreas dorsocentral y dorsoposterior telencefálicas, el núcleo entopeduncular, la habénula y el núcleo interpeduncular, el núcleo del istmo, las células euridendroides del cerebelo y el gris central. En cambio, otras regiones presentan inmunorreactividad para proteínas ligantes de calcio, pero en ellas no hay neuronas positivas para sintasa del óxido nítrico como, por ejemplo, los núcleos anterior y posterior del túber, el núcleo rojo, el núcleo lateral de la válvula y la oliva.

\section{Otros neurotransmisores y sustancias neuroactivas}

Además de los estudios que hemos citado hasta este momento, en los que se hace referencia a sustancias con una amplia distribución dentro del Sistema Nervioso adulto de diversas especies de teleósteos, se han realizado descripciones de la distribución de algunas sustancias que se encuentran restringidas a zonas muy 
concretas. Algunas de ellas se localizan en regiones que son inmunorreactivas para proteínas ligantes de calcio en la trucha arco iris, y por lo tanto podría haber colocalización en las mismas células. Así, las fibras y glomérulos olfatorios de la trucha arco iris positivos a calretinina poseen también péptido intestinal vasoactivo (Alonso y cols., 1989b). Los granos del bulbo olfatorio y las células del área ventroventral telencefálica, positivos para calretinina y parvalbúmina en la trucha arco iris poseen factor liberador de tirotropina en el salmón Oncorhynchus tshawytscha (Matz y Takahashi, 1994). Aparece vasotocina e isotocina en células localizadas en el núcleo preóptico de la trucha arco iris (Van Den Dungen y cols., 1982), núcleo en el que hemos detectado células inmunorreactivas para calretinina. En el núcleo del receso posterior, positivo a calretinina en la trucha arco iris, hay histamina en el espinoso Gasterosteus aculeatus (Ekström y cols., 1995). Se ha determinado la presencia de galanina en el área preóptica y el hipotálamo de la brema de mar Sparus aurata (Power y cols., 1996) y del gimnoto Apteronotus leptorhynchus (Yamamoto y cols., 1992), regiones con células inmunorreactivas para proteínas ligantes de calcio en varios de los núcleos que la constituyen. Dentro del estrato periventricular del techo óptico se ha descrito la presencia de cuerpos celulares inmunorreactivos para aromatasa en el carpín dorado Carassius auratus (Gelinas y Callard, 1993), que son positivos tanto para calretinina como para parvalbúmina en la trucha arco iris.

Otras sustancias aparecen en regiones en las que no se ha detectado inmunorreactividad para proteínas ligantes de calcio; así, por ejemplo, en el pez cebra Brachydanio rerio las neuronas del locus coeruleus son inmunorreactivas para colin acetiltransferasa (Ma, 1994). 


\section{ACTIVIDAD FUNCIONAL DE LAS PROTEÍNAS LIGANTES DE CALCIO EN EL SISTEMA NERVIOSO}

Calbindina D-28k, parvalbúmina y calretinina son proteínas ligantes de calcio pertenecientes a la familia del dominio EF, que presentan constantes de afinidad muy altas por el calcio, y no por otros iones que se presentan en el interior de las células en concentraciones similares. Por tanto, pueden actuar como un sistema tamponador muy eficaz que mantenga las concentraciones de calcio en el intervalo óptimo para la actividad celular. En este sentido, hay estudios que demuestran la actuación de parvalbúmina, calbindina D-28k y calretinina en la regulación de los niveles de calcio intracelular (Mattson y cols., 1991; Lledo y cols., 1992; Chard y cols., 1995; Dreessen y cols., 1996), mediando los efectos de este ión dentro de las células nerviosas. Sin embargo, las funciones concretas que desempeñan las proteínas ligantes de calcio en la fisiología celular aún no son bien conocidas, si bien existen datos fragmentarios sobre su posible papel. Así, la parvalbúmina puede controlar la homeostasis del calcio en las neuronas inhibidoras gabaérgicas que presentan alta velocidad de disparo (Celio, 1986), protegiéndolas de la entrada masiva de calcio que se produce durante los trenes de potenciales de acción. La calbindina D-28k está relacionada con la regulación de la neurotransmisión excitatoria en sinapsis hipocampales (Chard y cols., 1995). Por último, además de su función común con el resto de proteínas del grupo, se ha descrito que la calretinina actúa como inhibidor de la fosforilación proteica (Yamaguchi y cols., 1991).

Muchos de los procesos que transcurren a lo largo del desarrollo del Sistema Nervioso se encuentran modulados por el calcio. Debido a su capacidad para mantener la homeostasis del ión, se ha postulado que calbindina D-28k, parvalbúmina y calretinina podrían controlar diversos fenómenos durante la ontogenia (Rasmussen y Means, 1989). La parvalbúmina aparece en ocasiones en neuroblastos en migración (Hogan y Berman, 1994), pudiendo además regular la síntesis de componentes de 
membrana en las neuritas en crecimiento (Braun y cols., 1986). Sin embargo, la aparición de parvalbúmina en la mayoría de las regiones encefálicas comienza cuando las neuronas han alcanzado su posición definitiva y han establecido conexiones funcionales (Solbach y Celio, 1991). En este sentido, la parvalbúmina se asocia con la maduración funcional en el sistema visual en desarrollo (Hendrickson y cols., 1991). Sin embargo, en algunas subpoblaciones de neuronas gabaérgicas la aparición de parvalbúmina está retrasada respecto al inicio de la actividad de las mismas (Solbach y Celio, 1991). En el caso de la trucha arco iris existen regiones, como los núcleos vestibulares o el cerebelo, en las que puede observarse una correlación del patrón de inmunorreactividad con la maduración neuronal. Sin embargo, en la mayoría de regiones del Sistema Nervioso Central de la trucha arco iris la expresión de esta proteína comienza en momentos tardíos del desarrollo, en ocasiones juveniles, en los que la inmensa mayoría de las células nerviosas ya están completamente diferenciadas.

En el Sistema Nervioso Central de mamíferos se ha asociado a la calbindina D28k con el control de los procesos de diferenciación y sinaptogénesis neuronal que se producen durante la ontogenia (Enderlin y cols., 1987). Aunque la expresión de calbindina se produce mayoritariamente en neuronas, se ha descrito también su presencia en células gliales durante el desarrollo (Enderlin y cols., 1987; Crespo y cols., 1995). En el telencéfalo de embriones de ratón aparece calbindina D-28k en células de glía radial (Liu y Graybiel, 1992), de características similares a las descritas por nosotros en la trucha arco iris. Se ha propuesto que los procesos radiales inmunorreactivos para calbindina D-28k podrían regular la proliferación celular en las regiones en que aparecen. En nuestro estudio, la inmunotinción con el anticuerpo monoclonal McAB 300 se observa por primera vez en un estadio embrionario muy temprano en células de glía radial localizadas en la placa del suelo. Esta región guía a los conos de crecimiento durante el desarrollo embrionario temprano en el pez cebra Brachydanio rerio (Greenspoon y cols., 1995). Además, aparecen células gliales 
radiales inmunorreactivas a calbindina D-28k cuyos procesos marcan rutas de migración ya definidas previamente en el diencéfalo de la trucha arco iris, como la que organiza la aparición del núcleo difuso del torus lateralis en el diencéfalo (Corujo y Anadón, 1990), la formación de la capa molecular del cerebelo (Pouwels, 1978a,b,c,d), y la migración celular a través de los estratos del techo óptico mesencefálico (Sharma, 1975; Pinganaud, 1980; Mansour-Robaey y Pinganaud, 1990).

Respecto a la función de la calretinina durante el desarrollo, se la ha involucrado en el control de los niveles de calcio durante la mitosis (Gotzos y cols., 1992), y se ha tomado como índice de madurez de los elementos neuronales en el oído interno del ratón, ya que su patrón de desarrollo discurre paralelamente a la maduración morfológica y fisiológica de las neuronas inmunorreactivas (Dechesne y cols., 1994). En nuestro estudio hemos podido observar que el marcaje para calretinina en la trucha arco iris evoluciona en paralelo con el desarrollo morfofuncional en regiones como la médula espinal, el diencéfalo, el cerebelo, el sistema vestibuloacústico, la vía visual, y el sistema olfatorio, cuyo desarrollo ha sido previamente estudiado mediante técnicas morfológicas y/o fisiológicas (Leghissa, 1942; Sharma, 1975; Pouwels y cols., 1978a,b,c,d; Pinganaud, 1980; Zielinski y Hara, 1988; Corujo y Anadón, 1990; Körtje y cols., 1991; Becerra y cols., 1994b).

Una de las supuestas funciones de las proteínas ligantes de calcio que más atención ha recibido es su posible papel neuroprotector. Así, la calretinina actúa como protector frente a la excitotoxicidad provocada por calcio en neuronas corticales en cultivo (Lukas y Jones, 1994). También se ha demostrado la supervivencia selectiva de neuronas inmunorreactivas para calretinina en enfermedades neurodegenerativas como la enfermedad de Alzheimer (Hof y cols., 1993), o su resistencia a la toxicidad mediada por citoquinas en el cerebro de pacientes con el síndrome de inmunodeficiencia adquirida (Diop y cols., 1996). Por otro lado, la calbindina D-28k podría proteger a las neuronas contra procesos de excitotoxicidad mediada por calcio 
(Mattson y cols., 1991; Iacopino y cols., 1994). La parvalbúmina está presente en neuronas hipocampales resistentes a isquemia (Tortosa y Ferrer, 1994), y las neuronas más resistentes a la degeneración en la esclerosis lateral amiotrófica poseen parvalbúmina (Alexianu y cols., 1994; Reiner y cols., 1995). Sin embargo, existen datos que contradicen los anteriores, por lo que actualmente el papel neuroprotector de las proteínas ligantes de calcio es objeto de controversia. En este sentido, se ha descrito que la resistencia a excitotoxicidad de las neuronas calretinina positivas no se debe a la presencia de la proteína, sino a la existencia de una menor expresión de receptores para aminoácidos excitatorios en estas células (Möckel y Fischer, 1994). En apoyo de esta hipótesis existen estudios que indican que las células inmunorreactivas a calretinina no son resistentes a procesos de isquemia en el hipocampo (Freund y Magloczky, 1993). Se ha propuesto que la naturaleza del agente o proceso neurotóxico, en combinación con las propiedades neuroquímicas intrínsecas de las neuronas, pueden conducir a una respuesta diferente dependiendo de la región del Sistema Nervioso en que éstas se encuentren (Vogt-Weisenhorm y cols., 1996).

En todos los estudios anteriormente citados se da por supuesto que los cambios en los patrones de inmunorreactividad vienen determinados por variaciones en la cantidad de proteína presente dentro de la célula. Sin embargo, cambios detectados en la intensidad de la inmunorreactividad para calretinina en las diferentes fases del ciclo celular no se correlacionan con cambios en la concentración de proteína determinada mediante inmunoblot (Gotzos y cols., 1992). Recientemente se han realizado pruebas de la afinidad de los anticuerpos que nosotros hemos empleado en presencia de diferentes concentraciones de calcio (Winsky y Kuznicki, 1996). Se ha visto que la inmunorreactividad aumenta de manera proporcional a la concentración de calcio añadida (Winsky y Kuznicki, 1995;1996), lo que parece indicar que el anticuerpo se une con mayor afinidad a la proteína cuando ésta cambia su conformación al unirse al calcio. Ello explicaría los cambios en la intensidad de la inmunotinción que se 
producen en algunos estudios tras manipulación experimental, lo cual provoca cambios bruscos en las concentraciones de calcio en el interior de la célula (Mattson y cols., 1991; Sanna y cols., 1993b; Arai y cols., 1995). Todos estos datos aconsejan una mayor cautela a la hora de interpretar las variaciones obtenidas en los patrones de inmunorreactividad para proteínas ligantes de calcio tras diferentes tratamientos experimentales o procesos neurodegenerativos. De cualquier modo, existen también evidencias de aumentos en la expresión de los ARN mensajeros que codifican las proteínas ligantes de calcio en el hipocampo tras estimulación de las vías aferentes (Lowenstein y cols., 1991). Ello nos indica la posibilidad de que existan mecanismos de regulación de la expresión proteica, y que estas se reflejen en variaciones de los patrones de inmunorreactividad para las proteínas ligantes de calcio. 


\section{CONCLUSIONES}


1.- Las proteínas ligantes de calcio son marcadores inmunocitoquímicos de poblaciones celulares específicas durante la ontogenia del Sistema Nervioso de la trucha arco iris.

2.- El anticuerpo monoclonal McAB 300 contra calbindina D-28k es un marcador glial durante el desarrollo del Sistema Nervioso de la trucha arco iris, apareciendo en células de glía radial, ependimocitos, astrocitos, y células gliales perineuronales.

3.- Los anticuerpos contra calretinina y parvalbúmina marcan poblaciones específicas de neuronas en diferentes estadios ontogenéticos. La parvalbúmina aparece, además, en ependimocitos y oligodendrocitos interfasciculares en los estadios más avanzados del desarrollo.

4.- Durante la ontogenia del Sistema Nervioso de la trucha arco iris, la calretinina es la más temprana en su expresión, apareciendo durante el desarrollo embrionario a los $150^{\circ}$-día, tanto en el Sistema Nervioso Central como en el Sistema Nervioso Periférico. El marcaje para calbindina D-28k se observa por primera vez a los $200^{\circ}$-día en el Sistema Nervioso Central, y a los $300^{\circ}$-día en el Sistema Nervioso Periférico. La parvalbúmina aparece a los $250^{\circ}$-día de vida embrionaria en el Sistema Nervioso Periférico, en un estadio intermedio entre la calretinina y la calbindina D-28k, pero es la que más tarde comienza a expresarse durante el desarrollo del Sistema Nervioso Central, seis días después de la eclosión.

5.- Con respecto a la distribución espacial, la expresión de calretinina durante el desarrollo embrionario del Sistema Nervioso Central de la trucha arco iris comienza en el mielencéfalo y en la médula espinal. Más tardíamente, aunque también durante el desarrollo embrionario, aparece inmunorreactividad para calretinina en el diencéfalo, el mesencéfalo y el telencéfalo. El marcaje para calretinina en el metencéfalo aparece después de la eclosión. 
6.- Dentro del Sistema Nervioso Central de la trucha arco iris, la inmunorreactividad para parvalbúmina se inicia a los seis días posteclosión en regiones diencefálicas (núcleo del fascículo longitudinal medial), metencefálicas (células de Purkinje) y mielencefálicas (núcleos del área octavolateral), mientras que aparecen mucho más tardíamente, en estadios juveniles, en el telencéfalo, mesencéfalo y médula espinal.

7.- El marcaje para calbindina D-28k en el Sistema Nervioso Central de la trucha arco iris se produce por primera vez durante el desarrollo embrionario en células gliales radiales localizadas en la placa del suelo del diencéfalo, del mielencéfalo y de la médula espinal. En los estadios finales del desarrollo embrionario aparece inmunorreactividad para calbindina D-28k en el mesencéfalo. Las regiones mas tardías en expresar calbindina D-28k son el telencéfalo y el metencéfalo, en las que se observa marcaje por primera vez en estadios posteclosión.

8.- De modo general, el número de elementos inmunorreactivos para proteínas ligantes de calcio, así como su tamaño e intensidad de marcaje aumenta a lo largo del desarrollo en las diferentes regiones del Sistema Nervioso de la trucha arco iris. Ello no obstante, hemos encontrado expresión transitoria de calretinina en la habénula, y en dos regiones mesencefálicas, el estrato marginal del techo óptico y el núcleo interpeduncular. En ningun caso hemos observado expresión transitoria de parvalbúmina o de calbindina D-28k.

9.- Los patrones de expresión de proteínas ligantes de calcio evolucionan en paralelo a fenómenos conocidos que se producen durante el desarrollo, como son la maduración tardía del telencéfalo, los gradientes de migración celular en el diencéfalo y el cerebelo, el establecimiento de las aferencias retinianas en el techo óptico, y la organización de las vías nerviosas del sistema vestibuloacústico. 
10.- El orden en que se expresan las tres proteínas durante el desarrollo en la trucha arco iris es el mismo que en mamíferos. Sin embargo, existen diferencias significativas en las características de los elementos inmunoteñidos, en la evolución del patrón de inmunorreactividad durante el desarrollo y en su distribución final en el organismo adulto.

11.- Comparando nuestros resultados con los descritos para otros neurotransmisores y sustancias neuroactivas en el Sistema Nervioso de teleósteos, podemos concluir que hay coincidencias parciales en la distribución de proteínas ligantes de calcio con otros marcadores; pero en ningún caso se aprecia un solapamiento general en la evolución del marcaje a lo largo del desarrollo o en su localización en el adulto.

12.- El Sistema Nervioso de teleósteos presenta una estructura neuroquímica tan compleja como el de mamíferos, del que se diferencia por una evolución divergente que se refleja, entre otras características, en el patrón de distribución espacio-temporal de proteínas ligantes de calcio. La organización del Sistema Nervioso de la trucha arco iris no puede ser, por tanto, considerada un modelo simplificado de la de vertebrados anamniotas. 
Bibliografía - 1 -

\section{BIBLIOGRAFÍA}


Abbott, L. C. y D. M. Jacobowitz (1995). Development of calretinin-immunoreactive unipolar brush-like cell and an afferent pathway to the embryonic and early postnatal mouse cerebellum. Anat. Embryol., 191: 541-559.

Alcántara, S., I. Ferrer y E. Soriano (1993). Postnatal development of parvalbumin and calbindin D28K immunoreactivities in the cerebral cortex of the rat. Anat. Embryol., 188: 63-73.

Alcántara, S. y I. Ferrer (1994). Postnatal development of parvalbumin immunoreactivity in the cerebral cortex of the cat. J. Comp. Neurol., 348: 133149.

Alexianu, M. E., B.-K. Ho, H. Mohamed, V. La Bella, G. Smith y S. H. Appel (1994). The role of calcium-binding proteins in selective motoneuron vulnerability in amyotrophic lateral sclerosis. Ann. Neurol., 36: 846-857.

Allison, A. C. (1953). The morphology of the olfactory system in the vertebrates. Biol. Rev., 28: 195-244.

Alonso, J. R., J. Lara, J. J. Miguel y J. Aijón (1987). Ruffed cells in the olfactory bulb of freshwater teleosts. I. Golgi impregnation. J. Anat., 155: 101-107.

Alonso, J. R. (1987). El bulbo olfatorio de los teleósteos de agua dulce. Tesis Doctoral. Universidad de Salamanca.

Alonso, J. R., J. Lara, R. Coveñas y J. Aijón (1988). Two types of mitral cells in the teleost olfactory bulb. Neurosci. Res. Comm., 3: 113-118.

Alonso, J. R., R. Coveñas, J. Lara, R. Arévalo, M. de León y J. Aijón (1989a). Tyrosine hydroxylase immunoreactivity in a subpopulation of granule cells in the olfactory bulb of teleost fish. Brain Behav. Evol., 34: 318-324.

Alonso, J. R., R. Coveñas, J. Lara, M. de León y J. Aijón (1989b). Distribution of vasoactive intestinal polypeptide-like immunoreactivity in the olfactory bulb of the rainbow trout (Salmo gairdneri). Brain Res., 490: 385-389.

Alonso, J. R., R. Coveñas, J. Lara, M. de León, R. Arévalo y J. Aijón (1990). Interspecies differences in the substance $\mathrm{P}$ - and vasoactive intestinal polypeptide-like immunoreactivities in the olfactory bulb of Salmo gairdneri and Barbus meridionalis. J. Neurosci. Res., 25: 103-111. 
Alonso, J. R., R. Arévalo, J. G. Briñón, J. Lara, E. Weruaga y J. Aijón (1992). Parvalbumin immunoreactive neurons and fibres in the teleost cerebellum. Anat. Embryol., 184: 355-361.

Alonso, J. R., R. Arévalo, A. Porteros, J. G. Briñón, J. Lara y J. Aijón (1993). Calbindin D-28k and NADPH-diaphorase activity are localized in different populations of periglomerular cells in the rat olfactory bulb. J. Chem. Neuroanat., 6: 1-6.

Alonso, J. R., R. Arévalo, E. García-Ojeda, A. Porteros, J. G. Briñón y J. Aijón (1995). NADPH-diaphorase active and calbindin D-28k-immunoreactive neurons and fibers in the olfactory bulb of the hedgehog (Erinaceus europaeus). J. Comp. Neurol., 351: 307-327.

Altman, J. (1963). Autoradiographic investigation of cell proliferation in the brains of rats and cats. Anat. Rec., 145: 573-591.

Altman, J. y S. A. Bayer (1978). Development of the diencephalon in the rat. I. Autoradiographic study of the time of origin and settling patterns of neurons of the hypothalamus. J. Comp. Neurol., 182: 945-972.

Altman, J. y S. A. Bayer (1988). Development of the rat thalamus: II. Time and site of origin and settling pattern of neurons derived from the anterior lobule of the thalamic neuroepithelium. J. Comp. Neurol., 275: 378-405.

Amano, M., Y. Oka, K. Aida, N. Okumoto, S. Kawashima y Y. Hasegawa (1991). Immunocytochemical demonstration of salmon GnRH and chicken GnRH-II in the brain of the masu salmon, Oncorhynchus masou. J. Comp. Neurol., 314: 587-597.

Andressen, C., I. Blümcke y M. R. Celio (1993). Calcium binding proteins: selective markers of nerve cells. Cell Tissue Res., 271: 181-208.

Anglister, L., I. C. Farber, A. Shahar y A. Grinvald (1982). Localization of voltagesensitive calcium channels along developing neurites: their possible role in regulating neurite elongation. Dev. Biol., 94: 351-365.

Anken, R. H. y H. Rahmann (1996). An atlas of the distribution of NADPHdiaphorase in the brain of the highly derived swordtail fish Xiphophorus helleri (Atherinoformes: Teleostei). J. Brain Res., 37: 421-449. 
Antal, M. y E. Polgár (1993). Development of calbindin-D28k immunoreactive neurons in the embryonic chick lumbosacral spinal cord. Eur. J. Neurosci., 5: 782-794.

Anthony, F. A., J. A. Babich y S. K. Shrama (1984). Troponin is unlikely to occur in the bovine and chick forebrain. J. Neurochem., 42: 1343-1349.

Arai, R., L. Winsky, M. Arai y D. M. Jacobowitz (1991). Immunohistochemical localization of calretinin in the rat hindbrain. J. Comp. Neurol., 310: 21-44.

Arai, R., D. M. Jacobowitz y I. Nagatsu (1995). Up-regulation of calretinin in the supraoptic nucleus of the rat after chronic salt loading. Brain Res., 673: 339343.

Arévalo, R., J. R. Alonso, J. Lara, J. G. Briñón y J. Aijón (1991). Ruffed cells in the olfactory bulb of freshwater teleosts. II. A Golgi/EM study of the ruff. J. Hirnforsch., 32: 477-484.

Arévalo, R., J. R. Alonso, J. G. Briñón, E. García-Ojeda, A. Velasco, J. Lara y J. Aijón (1992). An atlas of the brain of the tench (Tinca tinca L., 1758; Cyprinidae, Teleostei). J. Hirnforsch., 33: 487-97.

Arévalo, R., J. R. Alonso, E. García-Ojeda, J. G. Briñón, C. Crespo y J. Aijón (1995a). NADPH-diaphorase in the central nervous system of the tench (Tinca tinca L., 1758). J. Comp. Neurol., 352: 398-420.

Arévalo, R., J. R. Alonso, A. Porteros, J. G. Briñón, C. Crespo, J. Lara y J. Aijón (1995b). Calretinin-like immunoreactivity in the optic tectum of the tench (Tinca tinca L.). Brain Res., 671: 112-118.

Ariëns-Kappers, C. U., G. C. Huber y E. C. Crosby (1936). The Comparative Anatomy of the Nervous System of Vertebrates, including Man. Nueva York: Hafner Publishing Co.

Bailhache, T., A. Arazam, H. Klungland, P. Aleström, B. Breton y P. Jego (1994). Localization of salmon gonadotropin-releasing hormone mRNA and peptide in the brain of Atlantic salmon and rainbow trout. J. Comp. Neurol., 347: 444454.

Baimbridge, K. G. y J. J. Miller (1982). Immunohistochemical localization of calcium-binding protein in the cerebellum, hippocampal formation and olfactory bulb of the rat. Brain Res., 245: 223-229. 
Baimbridge, K. G., J. J. Miller y C. O. Parkes (1982). Calcium-binding protein distribution in the rat brain. Brain Res., 239: 519-525.

Bastianelli, E. y R. Pochet (1993). Transient expression of calretinin during development of chick cerebellum. Comparison with calbindin D-28k. Neurosci. Res., 17: 53-61.

Bastianelli, E. y R. Pochet (1995). Calmodulin, calbindin-D28k, calretinin and neurocalcin in rat olfactory bulb during postnatal development. Dev. Brain Res., 87: 224-227.

Bastianelli, E., A. S. Polans, H. Hidaka y R. Pochet (1995a). Differential distribution of six calcium-binding proteins in the rat olfactory epithelium during postnatal development and adulthood. J. Comp. Neurol., 354: 395-409.

Bastianelli, E., K. Takamatsu, K. Okazaki, H. Hidaka y R. Pochet (1995b). Hippocalcin in rat retina. Comparison with calbindin-D28k, calretinin and neurocalcin. Exp. Eye Res., 60: 257-266.

Bauchot, R., M. Diagne y J.-M. Ribet (1979). Post-hatching growth and allometry of the Teleost brain. J. Hirnforsch., 20: 29-34.

Bäuerle, A. y H. Rahmann (1993). Morphogenetic differentiation of the brain of the cichlid fish, Oreochromis mossambicus. J. Hirnforsch., 34: 375-386.

Becerra, M. (1989). Estudio del desarrollo ontogénico del laberinto de Salmo trutta fario L. Tesis Doctoral. Universidad de Santiago de Compostela.

Becerra, M., M. J. Manso, M. I. Rodríguez-Moldes y R. Anadón (1994a). The structure and development of dopaminergic interplexiform cells in the retina of the brown trout, Salmo trutta fario: a tyrosine hydroxylase immunocytochemical study. J. Anat., 185: 377-385.

Cowan, W. M. (1978). Aspects of neuronal development. En: R. Porter (eds.): Neurophysiology. III. International review of Physiology. Vol. 17. Baltimore: University Park Press, pp. 149-191.

Becerra, M., M. J. Manso, I. Rodríguez-Moldes y R. Anadón (1994b). Primary olfactory fibers project to the ventral telencephalon and preoptic region in trout (Salmo trutta): a developmental immunocytochemical study. J. Comp. Neurol., 342: 131-143. 
Becerra, M., M. J. Manso, I. Rodríguez-Moldes y R. Anadón (1995). Ontogeny of somatostatin-immunoreactive systems in the brain of the brown trout (Teleostei). Anat. Embryol., 191: 119-137.

Becerra, M., M. J. Manso, M. Becerra y R. Anadón (1996). A low molecular-weight calbindin-like protein $(9 \mathrm{KDa})$ is expressed in glial cells of the brain of the trout (teleosts). Eur. J. Neurosci. (Suppl.), 9: 142.

Benjelloun-Touimi, S., C. M. Jacque, P. Derer, F. De Vitry, R. Maunoury y P. Dupouey (1985). Evidence that mouse astrocytes may be derived from the radial glia. An immunohistochemical study of the cerebellum in the normal and releer mouse. J. Neuroimmunol., 9: 87-97.

Berchtold, M. y A. R. Means (1985). The $\mathrm{Ca}^{2+}$-binding protein parvalbumin: Molecular cloning and developmental regulation of mRNA abundance. Proc. Natl. Acad. Sci. USA, 82: 1414-1418.

Berchtold, M. (1989). Parvalbumin genes from human and rat are identical in intron/exon organization and containing highly homologous regulatory elements and coding sequences. J. Mol. Biol., 210: 417-427.

Billard, R. y E. Peter (1982). A stereotaxic atlas and technique for nuclei of the diencephalon of rainbow trout (Salmo gairdneri). Reprod. Nutr. Develop., 22: $1-25$.

Bolliet, V. y M. A. Ali (1992). Immunohistochemical study of the development of serotoninergic neurons in the brain of the brook trout Salvelinus fontinalis. Brain Behav. Evol., 40: 234-249.

Braford, M. R. y R. G. Northcutt (1983). Organization of the diencephalon and pretectum of the ray-finned fishes. En: R. E. Davis and R. G. Northcutt (eds.): Fish Neurobiology. Vol. 2. Higher Brain Areas and Functions. Ann Arbor: The University of Michigan Press, pp. 117-163.

Brantley, R. K. y A. H. Bass (1988). Cholinergic neurons in the brain of a teleost fish (Porichthys notatus) located with a monoclonal antibody to choline acetyltransferase. J. Comp. Neurol., 275: 87-105.

Braun, K., M. Schacner, H. Scheich y C. W. Heizmann (1986). Cellular localization of the $\mathrm{Ca} 2+$ binding protein parvalbumin in the developing avian cerebellum. Cell Tissue Res., 243: 69-78. 
Briñón, J. G., J. R. Alonso, R. Arévalo, E. García-Ojeda, J. Lara y J. Aijón (1992). Calbindin D-28k-positive neurons in the rat olfactory bulb. Cell Tissue Res., 269: 289-297.

Briñón, J. G., M. Médina, R. Arévalo, J. R. Alonso, J. Lara y J. Aijón (1993). Volumetric analysis of the telencephalon and tectum during metamorphosis in a flatfish, the turbot Scophthalmus maximus. Brain Behav. Evol., 41: 1-5.

Briñón, J. G., J. R. Alonso, E. García-Ojeda, R. Arévalo, A. Porteros, A. Velasco y J. Aijón (1994). Parvalbumin imunoreactivity in the telencephalic hemispheres of the tench, Tinca tinca. Arch. Ital. Biol., 132: 1-12.

Brüning, G., R. Katzbach y B. Mayer (1995). Histochemical and immunocytochemical localization of nitric oxide synthase in the central nervous system of the goldfish, Carassius auratus. J. Comp. Neurol., 358: 353382.

Butler, A. B. y W. Hodos (1996). Comparative Vertebrate Neuroanatomy: Evolution and Adaptation. Nueva York: Wiley-Liss.

Buwalda, B., R. Naber, C. Nyakas y P. G. M. Luiten (1994). Nimopidine accelerates the postnatal development of parvalbumin and S-100b immunoreactivity in the rat brain. Dev. Brain Res., 78: 210-216.

Campbell, A. K. (1983). Intracellular Calcium. Chichester: John Wiley.

Cao, Q. L., X. X. Yan, X. G. Luo y L. J. Garey (1996). Prenatal development of parvalbumin immunoreactivity in the human striate cortex. Cerebral Cortex, 6: 620-630.

Celio, M. R., E. G. Gray y G. M. Yasargil (1979). Ultrastructure of the Mauthner axon collateral and its synapses in the goldfish spinal cord. J. Neurocytol., 8: 19-29.

Celio, M. R. y C. W. Heizmann (1981). Calcium-binding protein parvalbumin as a neuronal marker. Nature, 293: 300-302.

Celio, M. R. (1986). GABA neurons contain the calcium-binding protein parvalbumin. Science, 232: 995-997. 
Celio, M. R., L. Schärer, J. H. Morrison, A. W. Norman y F. E. Blom (1986). Calbindin D-28k immunoreactivity alternate with cytochrome oxidase richzones in some layers of the primate visual cortex. Nature, 323: 715-717.

Celio, M. R., W. Baier, P. de Viragh, L. Schärer y C. Gerday (1988). Monoclonal antibodies directed against the calcium binding protein parvalbumin. Cell Calcium, 9: 81-86.

Celio, M. R. (1989). Calcium binding proteins in the brain. Arch. Ital. Anat. Embriol., 94: 227-236.

Celio, M. R. (1990). Calbindin D-28k and parvalbumin in the rat nervous system. Neuroscience, 35: 375-475.

Celio, M. R., W. Baier, L. Schärer, G. H.J., P. A. de Viragh y A. W. Norman (1990). Monoclonal antibodies directed against the calcium-binding protein, calbindin D-28k. Cell Calcium, 11: 599-602.

Chard, P. S., J. Jordán, C. J. Marcuccilli, R. J. Miller, J. M. Leiden, R. P. Roos y G. D. Ghadge (1995). Regulation of excitatory transmission at hippocampal synapses by calbindin D28k. Proc. Natl. Acad. Sci. USA, 92: 5144-5148.

Chiba, A., S. Oka y Y. Honma (1994). Ontogenetic development of gonadotropinreleasing hormone-like immunoreactive neurons in the brain of the chum salmon, Oncorhynchus keta. Neurosci. Lett., 178: 51-54.

Corujo, A. y R. Anadón (1990). The development of the diencephalon of the rainbow trout (Salmo gairdneri Richardson). Thalamus and hypothalamus. J. Hirnforsch., 31: 669-680.

Cowan, W. M. (1979). The development of the brain. Sci. Amer., 241: 106-117.

Crespo, C., R. Arévalo, M. Rubio, J. Aijón, M. Santos, R. Vázquez y J. R. Alonso (1995). Calbindin D-28k and parvalbumin expression in mitotic cells of rat primary cortical cultures. Neuroreport, 6: 1137-1140.

Cunningham, T. J. (1982). Naturally ocurring neuron death and its regulation by developing neural pathways. Int. Rev. Cytol., 74: 163-186.

Dahl, D., D. C. Rueger y A. Bignami (1981). Vimentin, the 57000 molecular weight protein of fibroblast filaments, is the major cytoskeletal component in immature glia. Eur. J. Cell. Biol., 24: 191-196. 
De Lecea, L., J. A. Del Río y E. Soriano (1995). Developmental expression of parvalbumin mRNA in the cerebral cortex and hippocampus of the rat. Mol. Brain Res., 32: 1-13.

Dechesne, C. J., M. Thomasset, A. Brehier y A. Sans (1988). Calbindin (CaBP 28 $\mathrm{kDa}$ ) localization in the peripheral vestibular system of various vertebrates. Hearing Res., 33: 273-278.

Dechesne, C. J., D. Rabejac y G. Desmadryl (1994). Development of calretinin immunoreactivity in the mouse inner ear. J. Comp. Neurol., 346: 517-529.

Del Río, J. A., L. De Lecea, I. Ferrer y E. Soriano (1994). The development of parvalbumin immunoreactivity in the neocortex of the mouse. Dev. Brain Res., 81: 247-259.

Del Río, J. A., A. Martínez, M. Fonseca, C. Auladell y E. Soriano (1995). Glutamatelike immunoreactivity and fate of Cajal-Retzius cells in the murine cortex as identified with calretinin antibody. Cerebral Cortex, 5: 13-21.

Delmas, A. (1976). Vías y centros nerviosos. Barcelona: Toray-Masson.

Demêmes, D., J. Raymond, P. Atger, C. Grill, L. Winsky y C. J. Dechesne (1992). Identification of neuron subpopulations in the rat vestibular ganglion by calbindin-D 28K, calretinin and neurofilament proteins immunoreactivity. Brain Res., 582: 168-172.

Denizot, J. P., B. O. Bratton, A. Bréhier y M. Thomasset (1988). Immunohistochemical demonstration of calbindin-D 28k (CABP28K) in the spinal cord motoneurons of teleost fish. Cell Tissue Res., 254: 629-634.

Diop, A. G., C. Dussartre, D. Barthe y J. Hugon (1996). Neuroprotective properties of calretinin against the HIV-1gp120 toxicity. Neurosci. Res. Comm., 18: 107113.

Djebar, B., M. Bensouilah, M. Thomasset y J.-P. Denizot (1995). Immunohistochemical localization of calbindin-D28K (CABP 28K) in the projections of teleost fish electromotoneurons: a comparison of its distribution with endogenous calcium. Acta Histochem. Cytochem., 28: 291-298.

Donato, R. (1991). Perspectives in S-100 protein biology. Cell Calcium, 12: 713-726. 
Dreessen, J., C. Lutum, B. W. Schäffer, C. W. Heizmann y T. Knöpfel (1996). aParvalbumin reduces depolarization-induced elevations of cytosolic free calcium in human neuroblastoma cells. Cell Calcium, 19: 527-533.

Edelman, G. M. (1984). Modulation of cell adhesion during induction, histogenesis and perinatal development of the nervous system. Ann. Rev. Neurosci., 7: 339377.

Ekström, P., L. Nyberg y T. van Veen (1985). Ontogenetic development of serotoninergic neurons in the brain of a teleost, the three-spined stickleback: an immunohistochemical study. Dev. Brain Res., 17: 209-224.

Ekström, P., M. Reschke, H. W. M. Steinbusch y T. van Veen (1986). Distribution of noradrenaline in the brain of the teleost Gasterosteus aculeatus L: an immunohistochemical analysis. J. Comp. Neurol., 254: 297-313.

Ekström, P. (1987). Distribution of choline acetyltransferase-immunoreactive neurons in the brain of a cyprinid teleost (Phoxinus phoxinus L.). J. Comp. Neurol., 256: 494-515.

Ekström, P. y S. O. E. Ebbesson (1989). Distribution of serotonin-immunoreactive neurons in the brain of sockeye salmon fry (Oncorhynchus nerka). J. Chem. Neuroanat., 2: 201-213.

Ekström, P., T. Honkanen y H. W. M. Steinbusch (1990). Distribution of dopamineimmunoreactive neuronal perikarya and fibres in the brain of a teleost, Gasterosteus aculeatus. Comparison with tyrosine hydroxylase- and dopamineß-hydroxylase-immunoreactive neurons. J. Chem. Neuroanat., 3: 233-260.

Ekström, P., T. Honkanen y B. Borg (1992). Development of tyrosine hydroxylase-, dopamine- and dopamine ß-hydroxylase-immunoreactive neurons in a teleost, the three-spined stickleback. J. Chem. Neuroanat., 5: 481-501.

Ekström, P. (1994). Developmental changes in the brain-stem serotoninergic nuclei of teleost fish and neural plasticity. Cell. Molec. Neurobiol., 14: 381-393.

Ekström, P., B. I. Holmqvist y P. Panula (1995). Histamine-immunoreactive neurons in the brain of the teleost Gasterosteus aculeatus L. Correlation with hypothalamic tyrosine hydroxylase- and serotonin-immunoreactive neurons. J. Chem. Neuroanat., 8: 75-85. 
Ekström, P. y L.-M. Ohlin (1995). Ontogeny of GABA-immunorreactive neurons in the central nervous system in a teleost, Gasterosteus aculeatus L. J. Chem. Neuroanat., 94: 271-288.

Enderlin, S., A. W. Norman y M. R. Celio (1987). Ontogeny of the calcium-binding protein calbindin D-28k in the rat nervous system. Anat. Embryol., 177: 15-28.

Evered, D. y J. Whelan (1986). Calcium and the cell. Chichester: Wiley.

Faber, D. S. y H. Korn (1978). Electrophysiology of the Mauthner cell: basic properties, synaptic mechanisms and associated networks. En: D. S. Faber and H. Korn (eds.): Neurobiology of the Mauthner cell. Nueva York: Raven Press, pp. 47-131.

Feldman, S. C. y S. Christakos (1983). Vitamin D-dependent calcium-binding protein in the rat brain: biochemical and immunocytochemical characterization. Endocrinology, 112: 290-302.

Finger, T. E. (1983). Organization of the teleost cerebellum. En: R. J. Northcutt and R. E. Davis (eds.): Fish Neurobiology. Vol. I: Brain Stem and Sense Organs. Ann Arbor: The University of Michigan Press, pp. 261-284.

Fonseca, M., J. A. Del Río, A. Martínez, G. S. y E. Soriano (1995). Development of calretinin immunoreactivity in the neocortex of the rat. J. Comp. Neurol., 361: 177-192.

Frassoni, C., M. Bentivoglio, R. Spreafico, M. P. Sánchez, L. Puelles y A. Fairén (1991). Postnatal development of calbindin and parvalbumin immunoreactivity in the thalamus of the rat. Dev. Brain Res., 58: 243-249.

Freund, T. F. y Z. Magloczky (1993). Early degeneration of calretinin-containing neurons in the rat hippocampus after ischemia. Neuroscience, 56: 581-596.

Friauf, E. (1993). Transient appearance of calbindin-D-28k-positive neurons in the superior olivary complex of developing rats. J. Comp. Neurol., 334: 59-74.

Friauf, E. (1994). Distribution of calcium-binding protein calbindin-D28k in the auditory system of adult and developing rats. J. Comp. Neurol., 349: 193-211.

Gage, S. P. (1893). The brain of Diemyctilus viridescens from larval to adult life and comparison with the brain of Amia and of Petromyzon. Ithaca: The Wilder Quarter Century Book, pp. 259-314. 
García-Segura, L. M., D. Beatens, J. Roth, A. W. Norman y L. Orci (1984). Immunohistochemical mapping of calcium-binding protein in the rat central nervous system. Brain Res., 296: 75-86.

Geiger, B. y O. Ayalon (1992). Cadherines. Ann. Rev. Cell Biol., 8: 307-332.

Gelinas, D. y G. V. Callard (1993). Immunocytochemical and biochemical evidence for aromatase in neurons of the retina, optic tectum and retinotectal pathways in goldfish. J. Neuroendocrinol., 5: 635-641.

Gerday, C. (1988). Soluble calcium-binding proteins in vertebrates and invertebrates muscles. En: C. Gerday, L. Bollis and R. Gilles (eds.): Calcium and Calcium Binding Proteins. Molecular and Functional Aspects. Heidelberg: SpringerVerlag, pp. 23-39.

German, D. C., K. F. Manaye, P. K. Sonsalla y B. A. Brooks (1992). Midbrain dopaminergic cell loss in Parkinson's disease and MPTP-induced parkinsonism: sparing of calbindin-D28k-containing cells. Ann. NY Acad. Sci., 648: 42-62.

Giorgi, O., A. M. Deiana, S. Salvadori, D. Lecca y M. G. Corda (1994). Developmental changes in the content of dopamine in the olfactory bulb of the European eel (Anguilla anguilla). Neurosci. Lett., 172: 35-38.

Glew, R. H. y C. J. Coffee (1984). Calmodulin and parvalbumin: activator of human liver glucocerobrosidase. Arch. Biochem. Biophys., 229: 65-79.

Goodman, J. H., C. G. Wasterlain, W. F. Massarweh, E. Dean, A. L. Sollas y R. S. Sloviter (1993). Calbindin-D28k immunoreactivity and selective vulnerability to ischemia in the dentate gyrus of the developing rat. Brain Res., 606: 309314.

Gotzos, V., B. Schwaller, N. Hetzel, M. Bustos-Castillo y M. R. Celio (1992). Expression of the calcium binding protein calretinin in WiDr cells and its correlation to their cell cycle. Exp. Cell Res., 202: 292-302.

Greenspoon, S., C. K. Patel, S. Hashmi, R. R. Benhardt y J. Y. Kuwada (1995). The notochord and floor plate guide growth cones in the zebrafish spinal cord. J. Neurosci., 15: 5956-5965. 
Gregersen, H. J., C. W. Heizmann, U. Kaegi y M. R. Celio (1990). Ca2(+)-dependent mobility shift of parvalbumin in one- and two-dimensional gel-electrophoresis. Adv. Exp. Med. Biol., 269: 89-91.

Hamoir, G. (1968). The comparative biochemistry of fish sarcoplasmic proteins. Acta Zool. Pathol. (Antwerpen), 49: 69-76.

Heizmann, C. W. (1984). Parvalbumin, an intracellular calcium-binding protein; distribution, properties and possible roles in mammalian cells. Experientia, 40: 910-921.

Heizmann, C. W. y M. Berchtold (1987). Expression of parvalbumin and other $\mathrm{Ca}^{2+}$ binding proteins in normal and tumor cells: a topical review. Cell Calcium, 8: $1-41$.

Heizmann, C. W. y W. Hunziker (1989). Intracellular calcium-binding molecules. En: F. Bronner (eds.): Intracellular Calcium Regulation. Nueva York: Alan R. Liss, pp. 211-248.

Heizmann, C. W., J. Röhrenbeck y W. Kamphuis (1990). Parvalbumin, molecular and functional aspects. En: R. Pochet, D. E. M. Lawson and C. W. Heizmann (eds.): Calcium Binding Proteins in Normal and Transformed cells. Vol. 269. Nueva York: Plenum Press, pp. 57-66.

Hendrickson, A. E., J. F. M. Van Brederode, K. A. Mulligan y M. R. Celio (1991). Development of the calcium-binding proteins parvalbumin and calbindin in monkey striate cortex. J. Comp. Neurol., 307: 626-646.

Hepler, P. K. (1994). The role of calcium in cell division. Cell Calcium, 16: 322-330.

Herrick, C. J. (1948). The brain of the tiger salamander. Chicago: University of Chicago Press.

Hidaka, H., E. Carafoli, A. R. Means y T. Tanaka (1988). Calcium Protein Signaling. Nueva York: Plenum Press.

Highstein, S. M., R. Kitch, J. Carey y R. Baker (1992). Anatomical organization of the brainstem octavolateralis area of the oyster toadfish, Opsanus tau. J. Comp. Neurol., 319: 501-518. 
Hirose, G. y M. Jacobson (1979). Clonal organization of the central nervous system of the frog. I. Clones stemming from individual blastomeres of the 16-cell and earlier stages. Dev. Biol., 71: 191-202.

His, W. (1893). Vorschlage zur Einteilung des Gehirns. Arch. Anat. Entwicklungsgesch., 17: 172-179.

Hisaoka, K. K. y H. I. Battle (1958). The normal developmental stages of the zebrafish, Brachydanio rerio (Hamilton-Buchanan). J. Morphol., 102: 311-328.

Hockfield, A. y R. D. G. McKay (1985). Identification of major cell clases in the developing mammalian nervous system. J. Neurosci., 5: 3310-3318.

Hof, P. R., E. A. Nimchinsky, M. R. Celio, C. Bouras y J. H. Morrison (1993). Calretinin-immunoreactive neocortical interneurons are unaffected in Alzheimer's disease. Neurosci. Lett., 152: 145-148.

Hogan, D. y N. E. J. Berman (1993). Transient expression of calbindin-D28k immunoreactivity in layer $\mathrm{V}$ pyramidal neurons during postnatal development of kitten cortical areas. Dev. Brain Res., 74: 177-192.

Hogan, D. y N. E. J. Berman (1994). The development of parvalbumin and calbindin D-28k immunoreactive interneurons in kitten visual cortical areas. Dev. Brain Res., 77: 1-21.

Holmqvist, B. I. y P. Ekström (1991). Galanin-like immunoreactivity in the brain of teleosts: distribution and relation to substance $\mathrm{P}$, vasotocin and isotocin in the Atlantic salmon (Salmo salar). J. Comp. Neurol., 306: 361-381.

Holmqvist, B. I., T. Östholm, P. Alm y P. Ekström (1994). Nitric oxide synthase in the brain of a teleost. Neurosci. Lett., 171: 205-208.

Holmqvist, B. I. y P. Ekström (1995). Hypophysiotrophic systems in the brain of the Atlantic salmon. Neuronal innervation of the pituitary and the origin of pituitary dopamine and nonapeptides identified by means of combined carbocyanine tract tracing and immunocytochemistry. J. Chem. Neuroanat., 8: 125-145.

Hoogenboom, K. J. H. (1929). Das Gehirn von Polyodon folium lacep. Z. Mikrosk. Anat. Forsch., 18: 311-392. 
Hornby, P. J., D. T. Piekut y L. S. Demsky (1987). Localization of immunoreactive tyrosine hydroxylase in the goldfish brain. J. Comp. Neurol., 261: 1-14.

Hornby, P. J. y D. T. Piekut (1990). Distribution of catecholamine-synthesizing enzymes in goldfish brains: presumptive dopamine and norepinephrine neuronal organization. Brain Behav. Evol., 35: 49-64.

Hunzinker, W. y S. Schrickel (1988). Rat brain calbindin D-28k: six domain structure and extensive amino acid sequence homology with chick calbindin D28k. Mol. Endocrinol., 2: 465-473.

Iacopino, A. M. y S. Christakos (1990). Specific reduction of calcium-binding protein (28-kilodalton calbindin-D) gene expression in aging and neurodegenerative diseases. Proc. Natl. Acad. Sci. USA, 87: 4078-4082.

Iacopino, A. M., E. M. Quintero y E. K. Miller (1994). Calbindin D-28k: a potential neuroprotective protein. Neurodegeneration, 3: 1-20.

Ibáñez, T. (1990). Distribución de neuropéptidos, catecolaminas y proteínas ligantes de calcio en el telencéfalo de teleósteos: estudio inmunocitoquímico. Grado de Licenciatura. Universidad de Salamanca.

Ito, H. y R. Kishida (1978). Afferent and efferent fiber connections of the carp torus longitudinalis. J. Comp. Neurol., 181: 465-476.

Jacobowitz, D. M. y L. Winsky (1991). Immunocytochemical localization of calretinin in the forebrain of the rat. J. Comp. Neurol., 304: 198-218.

Jansen, J. K. S. y P. S. Enger (1996a). Pre- and postmetamorphic organization of the vestibular nuclear complex in the turbot examined by retrograde tracer substances. J. Comp. Neurol., 364: 677-689.

Jansen, J. K. S. y P. S. Enger (1996b). NADPH-diaphorase activity is asymmetrically distributed in the optic tectum during the period of eye migration in turbots. Acta Physiol. Scand., 157: 515-517.

Johnston, J. B. (1911). The telencephalon of ganoids and teleosts. J. Comp. Neurol., 21: 489-591.

Johnston, S. A., L. Maler y B. Tinner (1990). The distribution of serotonin in the brain of Apteronotus leptorhynchus: an immunohistochemical study. J. Chem. Neuroanat., 3: 429-465. 
Källen, B. (1951). Embryological studies on the nuclei and their homologization in the vertebrate forebrain. Kungl. Fysiogr. Sällsk. Handl., 62: 1-36.

Kennedy, M. B. (1989). Regulation of neuronal function by calcium. Trends Neurosci., 12: 417-420.

Khanna, N. C., M. Tokuda y D. M. Waisman (1988). The role of calcium-binding proteins in signal traduction. En: B. A. Cooke, R. J. King and B. van der Molen (eds.): Hormones and Their Actions. Amsterdam: Elsevier, pp. 63-92.

Kim, M.-H., Y. Oka, M. Amano, M. Kobayashi, K. Okuzawa, Y. Hasegawa, S. Kawashima, Y. Suzuki y K. Aida (1995). Immunocytochemical localization of sGnRH and cGnRH-II in the brain of goldfish, Carassius auratus. J. Comp. Neurol., 356: 72-82.

Kimmel, C. B., D. A. Kane y R. K. Ho (1991). Lineage specification during early embryonic development of the zebrafish. En: Cell-Cell Interactions in Early Development. Wiley-Liss, Inc., pp. 203-225.

King, J. S. (1966). A comparative investigation of neuroglia in representative vertebrates. J. Morphol., 119: 435-466.

Kishimoto, J., E. B. Keverne y P. C. Emson (1993). Calretinin, calbindin-D28k, and parvalbumin-like immunoreactivity in mouse chemoreceptor neurons. Brain Res., 610: 325-329.

Kosaka, T. y K. Hama (1982). Synaptic organization in the teleost olfactory bulb. J. Physiol. (Paris), 78: 707-719.

Kosaka, K., C. W. Heizmann y T. Kosaka (1994a). Calcium-binding protein parvalbumin-immunoreactive neurons in the rat olfactory bulb. 1. Distribution and structural features in adult rat. Exp. Brain Res., 99: 191-204.

Kosaka, K., C. W. Heizmann y T. Kosaka (1994b). Calcium-binding protein parvalbumin-immunoreactive neurons in the rat olfactory bulb. 2. Postnatal development. Exp. Brain Res., 99: 205-213.

Körtje, K. H., H. Weber y H. Rahmann (1991). Morphogenetic development of the area octavolateralis in the cichlid fish Oreochromis mossambicus. J. Hirnforsch., 32: 491-495. 
Kretsinger, R. H. (1980). Structure and evolution of calcium modulated proteins. CRC Crit. Rev. Biochem., 8: 119-174.

Kudo, H., H. Ueda, H. Kawamura, K. Aida y K. Yamauchi (1994). Ultrastructural demonstration of salmon-type gonadotropin-releasing hormone (sGnRH) in the olfactory system of masu salmon (Oncorhynchus masou). Neurosci. Lett., 166: 187-190.

Kuhlenbeck, H. (1973). The Central Nervous System of Vertebrates. Basilea: S. Karger.

Kuo, W. N., T. Blake, I. R. Chemman, J. Domínguez, J. Nicholson, K. Puente, P. Shells y J. Lowery (1986). Regulatory effects of S-100 protein and parvalbumin on protein kinases and phosphoprotein phosphatases from brain and skeletal muscle. Molec. Cell. Biochem., 71: 19-24.

Lara, J., M. I. Cuadrado, M. T. Alonso y J. Aijón (1983). Estructura general del techo óptico de Cyprinus carpio. Revista de la Real Academia de Ciencias Exactas, Físicas y Naturales de Madrid, LXXVII: 663-679.

Lara, J., J. Repérant, M. Médina, R. Ward y D. Miceli (1990). Regeneration of the retinotectal system in a flatfish: Scophtalmus maximus. J. Exp. Biol., 48: 313318.

Lara, J. M., A. Velasco, J. R. Alonso y J. Aijón (1995). The neuroglia in the CNS of teleost. En: E. Vernardakis and B. Roots (eds.): Neuron-glia interactions during phylogeny: I. Phylogeny and ontogeny of glial cells. Vol. 1. Totawa: Humana Press Inc., pp. 131-156.

Lavoie, B. y A. Parent (1991). Dopaminergic neurons expressing calbindin in normal and parkinsonian monkeys. Neuroreport, 2: 601-604.

Le Vine, S. M. y J. E. Goldman (1988). Embryonic divergence of oligodendrocyte and astrocyte lineages in developing rat cerebrum. J. Neurosci., 8: 3992-4006.

Leghissa, S. (1942). Le basi anatomiche nella evoluzione del "comportamento" durante lo sviluppo embrionale e post-embrionale di trota (Salmo fario, irideus e lacustris). Z. Anat. Entwicklungsgesch., 111: 601-675.

Liu, F.-C. y A. M. Graybiel (1992). Transient calbindin-D28k-positive systems in the telencephalon: ganglionic eminence, developing striatum and cerebral cortex. J. Neurosci., 12: 674-690. 
Lledo, P.-M., B. Somasundaram, A. J. Morton, P. C. Emson y W. T. Mason (1992). Stable transfection of calbindin-D28k into the GH3 cell line alters calcium currents and intracellular calcium homeostasis. Neuron, 9: 943-954.

Losier, B. y J. A. Matsubara (1990). Comparison of calbindin D 28k and cytochrome c oxidase in electrosensory nuclei of high- and low-frequency weakly electric fish (Gymnotiformes). Cell Tissue Res., 260: 29-39.

Lowenstein, D. H., M. F. Miles, F. Hatam y T. McCabe (1991). Up regulation of calbindin-d28k mRNA in the rat hippocampus following focal stimulation of the perforant path. Neuron, 6: 627-633.

López, R. (1996). Estudio cito-arquitectónico de la médula espinal de la trucha arcoiris Oncorhynchus mykiss (Walbaum, 1792). Tesis Doctoral. Universidad de Salamanca.

Lukas, W. y K. A. Jones (1994). Cortical neurons containing calretinin are selectively resistant to calcium overload and excitotoxicity in vitro. Neuroscience, 61: 307-316.

Lumsden, A. y R. Keynes (1989). Segmental patterns of neuronal development in the chick hindbrain. Nature, 337: 424-428.

Ma, P. M. (1994). Catecholaminergic systems in the zebrafish. I. Number, morphology, and histochemical characteristics of neurons in the locus coeruleus. J. Comp. Neurol., 344: 242-255.

Maejima, K., Y. Oka, M. K. Park y S. Kawashima (1994). Immunohistochemical double-labeling study of gonadotropin-releasing hormone (GnRH)immunoreactive cells and oxytocin-immunoreactive cells in the preoptic area of the dwarf gourami, Colisa lalia. Neurosci. Res., 20: 189-193.

Maler, L., S. Jande y D. E. M. Lawson (1984). Localization of vitamin D-dependent calcium binding protein in the electrosensory and electromotor system of high frequency gymnotid fish. Brain Res., 301: 166-170.

Maler, L., E. Sas, S. Johnston y W. Ellis (1991). An atlas of the brain of the electric fish Apteronotus leptorhynchus. J. Chem. Neuroanat., 4: 1-38.

Manso, M. J., M. Becerra, P. Molist, I. Rodríguez-Moldes y R. Anadón (1993). Distribution and development of catecholaminergic neurons in the brain of the 
brown trout. A tyrosine hydroxylase immunohistochemical study. J. Hinforsch., 2: 239-260.

Mansour-Robaey, S. y G. Pinganaud (1990). Quantitative and morphological study of cell proliferation during morphogenesis in the trout visual system. J. Hirnforsch, 31: 495-504.

Marino-Neto, J. y R. M. E. Sabbatini (1988). A stereotaxic atlas for the telencephalon of the siameses fighting fish (Betta splendens). Braz. J. Med. Biol. Res., 21: 971-986.

Martínez-Guijarro, F. J. y T. F. Freund (1992). Distribution of GABAergic interneurons immunoreactive for calretinin, calbindin D28K, and parvalbumin in the cerebral cortex of the lizard Podarcis hispanica. J. Comp. Neurol., 322: 449-460.

Martínez-Guijarro, F. J., J. M. Blasco-Ibáñez y C. López-García (1994). Postnatal increase of GABA- and parvalbumin- immunoreactive cells in the cerebral cortex of the lizard Podarcis hispanica. Brain Res., 634: 168-172.

Mattson, M. P. y S. B. Kater (1987). Calcium regulation of neurite elongation and growth cone motility. J. Neurosci., 7: 4034-4043.

Mattson, M. P., A. Taylor-Hunter y S. B. Kater (1988). Neurite outgrowth in individual neurons of a neuronal population is differentially regulated by calcium and cyclic AMP. J. Neurosci., 8: 1704-1711.

Mattson, M. P., B. Rychlik, C. Chu y S. Christakos (1991). Evidence for calciumreducing and excito-protective roles for the calcium-binding protein calbindin D-28k in cultured hippocampal neurons. Neuron, 6: 41-51.

Matz, S. P. y T. T. Takahashi (1994). Immunohistochemical localization of thyrotropin-releasing hormone in the brain of chinook salmon (Oncorhynchus tshawytscha). J. Comp. Neurol., 356: 214-223.

McCormick, C. A. y M. R. J. Braford (1993). The primary octaval nuclei and inner ear afferent projections in the otophysan Ictalurus punctatus. Brain Behav. Evol., 42: 48-68.

McDonald, T. J., C. Li y R. H. Wasserman (1995). Distribution of calbindin-D28k in the brain of the fetal sheep in late gestation. Brain Res., 675: 303-315. 
Meek, J., H. W. J. Joosten y H. W. M. Steinbusch (1989). The distribution of dopamine-immunoreactivity in the brain of the mormyrid teleost Gnathonemus petersii. J. Comp. Neurol., 281: 362-383.

Meek, J., H. W. J. Joosten y T. G. M. Hafmans (1993). Distribution of noradrenalineimmunoreactivity in the brain of the mormyrid teleost Gnathonemus petersii. J. Comp. Neurol., 328: 145-160.

Meek, J. y H. W. Joosten (1993). Tyrosine hydroxylase-immunoreactive cell groups in the brain of the teleost fish Gnathonemus petersii. J. Chem. Neuroanat., 6: 431-446.

Meredith, G. E. y A. B. Butler (1983). Organization of eighth nerve afferent projections from individual endorgans in the inner ear in the teleost Astronotus ocellatus. J. Comp. Neurol., 220: 44-62.

Médina, M., J. Repérant, S. Dufour, R. Ward, N. Le Belle y D. Miceli (1994). The distribution of GABA-immunoreactive neurons in the brain of the silver eel (Anguilla anguilla L.). Anat. Embryol., 189: 25-39.

Miettinen, R., A. I. Gulyas, K. G. Baimbridge, D. M. Jacobowitz y T. F. Freund (1992). Calretinin is present in non-pyramidal cells of the rat hippocampus. II. Co-existence with other calcium binding proteins and GABA. Neuroscience, 48: 29-43.

Miguel-Hidalgo, J. J., H. Ito y J. Lara (1991). Distribution of calbindinlike immunoreactive structures in the optic tectum of normal and eye-enucleated cyprinid fish. Cell Tissue Res., 265: 511-516.

Mitrofanis, J. (1992). Patterns of antigenic expression in the thalamic reticular nucleus of developing rats. J. Comp. Neurol., 320: 161-181.

Montero, M., B. Vidal, J. A. King, G. Tramu, F. Vandesande, S. Dufour y O. Kah (1994). Immunocytochemical localization of mammalian GnRH (gonadotropinreleasing hormone) and chicken GnRH-II in the brain of the european silver eel (Anguilla anguilla L.). J. Chem. Neuroanat., 7: 227-241.

Mori, K., J. Ikeda y O. Hayaishi (1990). Monoclonal antibody R2D5 reveals midsagittal radial glial system in postnatally developing and adult brainstem. Proc. Natl. Acad. Sci. USA, 8: 5489-5493. 
Morris, R. J., J. N. Beech y C. W. Heizmann (1988). Two distinct phases and mechanisms of axonal growth shown by primary vestibular fibres in the brain demostrated by parvalbumin immunohistochemistry. Neuroscience, 27: 571596.

Möckel, V. y G. Fischer (1994). Vulnerability to excitotoxic stimuli of cultured rat hippocampal neurons containing the calcium binding proteins calretinin and calbindin D28k. Brain Res., 684: 109-120.

Naito, N., E. G. de Jesus, Y. Nakai y T. Hirano (1993). Ontogeny of pituitary celltypes and the hypothalamo-hypophysial relationship during early development of chum salmon, Oncorhynchus keta. Cell Tissue Res., 272: 429-437.

Nieuwenhuys, R. (1963). The comparative anatomy of the actinopterygian forebrain. J. Hirnforsch., 6: 171-192.

Nieuwenhuys, R. (1964). Further studies on the general structure of the actinopterygian forebrain. Acta Morphol. Néerl. Scand., 6: 65-79.

Nieuwenhuys, R. y E. Pouwels (1983). The brain stem of actinopterygian fishes. En: R. G. Northcutt and R. E. Davis (eds.): Fish Neurobiology. Vol. 1: Brain Stem and Sense Organs. Ann Arbor: The University of Michigan Press, pp. 25-87.

Nieuwenhuys, R. y J. Meek (1990). The telencephalon of actinopterygian fishes. En: E. G. Jones and A. Peters (eds.): Cerebral Cortex. Vol. 8A, part I. Comparative structure and evolution of cerebral cortex. Nueva York: Plenum Press, pp. 3173.

Northcutt, R. G. y M. R. Braford (1980). New observations on the organization and evolution of the telencephalon of actinopterygian fishes. En: S. O. E. Ebesson (eds.): Comparative Neurology of the Telencephalon. Nueva York: Plenum Press, pp. 41-97.

Northmore, D. P. M., B. Williams y H. Vanegas (1983). The teleostean torus longitudinalis: responses related to eye movements, visuotopic mapping and functional relations with the optic tectum. J. Comp. Physiol., 150: 39-50.

Omura, Y. y M. Oguri (1993). Early development of the pineal photoreceptors prior to the retinal differentiation in the embryonic rainbow trout, Oncorhynchus mykiss (Teleostei). Arch. Histol. Cytol., 56: 283-291. 
Oppenheim, R. W. (1981). Neuronal cell death and some related regressive phenomena during neurogenesis: A selective historical review and progress report. En: W. H. Cowan (eds.): Studies in Developmental Neurobiology: Essay in Honor of Viktor Hamburger. Nueva York: Oxford University Press, pp. 74-133.

Orr, H. (1887). Contribution to the embryology of the lizard. J. Morphol., 1: 311-372.

Östholm, T., B. I. Holmqvist, P. Alm y P. Ekström (1994). Nitric oxide synthase in the CNS of the atlantic salmon. Neurosci. Lett., 168: 233-237.

Parhar, I. S. y M. Iwata (1994). Gonadotropin releasing hormone (GnRH) neurons project to growth hormone and somatolactin cells in the steelhead trout. Histochemistry, 102: 195-203.

Parhar, I. S., M. Iwata, D. W. Pfaff y M. Schwanzel-Fukuda (1995). Embryonic development of gonadotropin-releasing hormone neurons in the sockeye salmon. J. Comp. Neurol., 362: 256-270.

Parmentier, M., M. Ghysens, F. Rypens, D. M. Lawson, J. L. Pasteels y R. Pochet (1987). Calbindin in vertebrate classes: immunohistochemical localization and Western blot analysis. Gen. Comp. Endocrinol., 65: 399-407.

Pasteels, B., J. Rogers, F. Blachier y R. Pochet (1990). Calbindin and calretinin localization in retina from different species. Visual Neurosci., 5: 1-16.

Pechère, J. F., J. Derancourt y J. Haiech (1977). The function of parvalbumin. Fed. Eur. Biochem. Soc. Lett., 75: 111-114.

Persechini, A., N. D. Moncrief y R. H. Kretsinger (1989). The EF-hand family of calcium-modulated proteins. Trends Neurosci., 12: 462-467.

Peter, R. E. y V. E. Gill (1975). A stereotaxic atlas and technique for forebrain nuclei of the goldfish, Carassius auratus. J. Comp. Neurol., 159: 69-102.

Peter, R. E., M. J. Macey y V. E. Gill (1975). A stereotaxic atlas and technique for forebrain nuclei of the killifish, Fundulus heteroclitus. J. Comp. Neurol., 159: 103-128.

Pérez, E., F. Adrio, M. A. Rodríguez, I. Rodríguez-Moldes y R. Anadón (1996). NADPH-diaphorase histochemistry reveals oligodendrocytes in the rainbow trout (teleosts). Neurosci. Lett., 205: 83-86. 
Pickavance, L. C., W. A. Staines y J. N. Fryer (1992). Distributions and colocalization of neuropeptide $\mathrm{Y}$ and somatostatin in the goldfish brain. J. Chem. Neuroanat., 5: 221-233.

Pinganaud, G. (1980). Le développement du système visuel primaire de Salmo irideus. Archives d'Anatomie Microscopique, 69: 215-231.

Pinol, M. R., U. Kägi, C. W. Heizmann, B. Vogel, J. M. Séquier, W. Haas y W. Hunzinker (1990). Poly- and monoclonal antibodies against recombinant rat brain calbindin D-28K were produced to map its selective distribution in the Central Nervous System. J. Neurochem., 54: 1827-1833.

Pouwels, E. (1978a). On the development of the cerebellum of the trout, Salmo gairdneri. I. Patterns of cell migration. Anat. Embryol., 152: 291-308.

Pouwels, E. (1978b). On the development of the cerebellum of the trout, Salmo gairdneri. II. Early development. Anat. Embryol., 152: 309-324.

Pouwels, E. (1978c). On the development of the cerebellum of the trout, Salmo gairdneri. III. Development of neuronal elements. Anat. Embryol., 153: 37-54.

Pouwels, E. (1978d). On the development of the cerebellum of the trout, Salmo gairdneri. IV. Development of the pattern of connectivity. Anat. Embryol., 153: 55-65.

Power, D. M., A. V. M. Canario y P. M. Ingleton (1996). Somatotropin releaseinhibiting factor and galanin innervation in the hypothalamus and pituitary of seabream (Sparus aurata). Gen. Comp. Endocrinol., 101: 264-274.

Presson, J. C. (1994). Immunocytochemical reactivities of precursor cells and their progeny in the ear of a cichlid fish. Hearing Res., 80: 1-9.

Rakic, P. (1972). Mode of cell migration to the superficial layers of fetal monkey neocortex. J. Comp. Neurol., 145: 61-84.

Rasmussen, C. D. y A. R. Means (1989). Calmodulin, cell growth and gene expression. Trends Neurosci., 12: 433-438.

Raymond, P. A. y S. S. Easter Jr. (1983). Postembryonic growth of the optic tectum in goldfish. I. Location of germinal cells and numbers of neurons produced. J. Neurosci., 3: 1077-1091. 
Raymond, P. A., S. S. Easter Jr., J. A. Burnham y M. K. Powers (1983). Postembryonic growth of the optic tectum in goldfish. II. Modulation of cell proliferation by retinal fiber input. J. Neurosci., 3: 1092-1099.

Reaves, T. A. J. y J. N. Hayward (1979). Immunocytochemical identification of enkephalinergic neurons in the hypothalamic magnocellular preoptic nucleus of goldfish, Carassius auratus. Cell. Tissue Res., 200: 147-151.

Reichenbach, A. (1990). Radial glial cells are present in the velum medullare of adult monkeys. J. Hirnforsch., 31: 2690-2692.

Reiner, A., L. Medina, G. Figueredo-Cardenas y S. Anfinson (1995). Brainstem motoneuron pools that are selectively resistant in amyotrophic lateral sclerosis are preferentially enriched in parvalbumin: evidence from monkey brainstem for a calcium mediated mechanism in sporadic ALS. Exp. Neurol., 131: 239250.

Ren, K. y M. A. Ruda (1994). A comparative study of the calcium-binding proteins calbindin-D28K, calretinin, calmodulin and parvalbumin in the rat spinal cord. Brain Res. Rev., 19: 163-179.

Retzlaff, E. (1957). A mechanism for excitation and inhibition of the Mauthner's cells in teleosts: a histological and neurophysiological study. J. Comp. Neurol., 107: 209-225.

Résibois, A. y J. H. Rogers (1992). Calretinin in rat brain: an immunohistochemical study. Neuroscience, 46: 101-134.

Roberts, B. L., G. E. Meredith y S. Maslam (1989). Immunocytochemical analysis of the dopamine system in the brain and spinal cord of the European eel, Anguilla anguilla. Anat. Embryol., 180: 401-412.

Roberts, B. L., S. Maslam, G. Scholten y W. Smit (1995). Dopaminergic and GABAergic cerebrospinal fluid-contacting neurons along the central canal of the spinal cord of the eel and trout. J. Comp. Neurol., 354: 423-437.

Rogers, J. H. (1987). Calretinin: a gene for a novel calcium-binding protein expressed principally in neurons. J. Cell Biol., 105: 1343-1353.

Rogers, J. H. (1989a). Immunoreactivity for calretinin and other calcium-binding proteins in cerebellum. Neuroscience, 31: 711-721. 
Rogers, J. H. (1989b). Two calcium-binding proteins mark many chick sensory neurons. Neuroscience, 31: 697-709.

Rogers, J. H. y A. Résibois (1992). Calretinin and calbindin-D28k in rat brain: patterns of partial co-localization. Neuroscience, 51: 843-865.

Roisen, F. J., F. J. Wilson, G. Yorke, M. Inczedy-Marcsek y T. Hirabayashi (1983). Immunohistochemical localization of troponin-C in cultured neurons. J. Muscle Res. Cell Motil., 4: 163-175.

Romer, A. S. (1970). Vertebrate Paleontology. Chicago: University of Chicago Press.

Rubin, R. P., G. B. Weiss y J. W. Putney (1985). Calcium in Biological Systems. Nueva York: Plenum Press.

Sandell, J. H., S. C. Martin y G. Heinrich (1994). The development of GABA immunoreactivity in the retina of the zebrafish (Brachydanio rerio). J. Comp. Neurol., 345: 596-601.

Sanna, P. P., K. T. Keyser, T. J. Deerink, M. H. Ellisman, H. J. Karten y F. E. Bloom (1992). Distribution and ontogeny of parvalbumin immunoreactivity in the chicken retina. Neuroscience, 47: 745-751.

Sanna, P. P., K. T. Keyser, T. J. Deerink, M. H. Ellisman, H. J. Karten y F. E. Bloom (1993a). Distribution of parvalbumin immunoreactivity in the vertebrate retina. Brain Res., 600: 141-150.

Sanna, P. P., M. R. Celio, F. E. Bloom y M. Rende (1993b). Presumptive Renshaw cells contain decreased calbindin during recovery from sciatic nerve lesions. Proc. Natl. Acad. Sci. USA, 90: 3048-3052.

Sas, E. y L. Maler (1991). Somatostatin-like immunoreactivity in the brain of an electric fish (Apteronotus leptorhynchus) identified with monoclonal antibodies. J. Chem. Neuroanat., 4: 155-186.

Sauer, F. C. (1935). The cellular structure of the neural tube. J. Comp. Neurol., 63: 13-23.

Sánchez, M. P., C. Frassoni, G. Alvarez-Bolado, R. Spreafico y A. Fairén (1992). Distribution of calbindin and parvalbumin in the developing somatosensory cortex and its primordium in the rat: an immunocytochemical study. J. Neurocytol., 21: 717-736. 
Schmechel, D. E. y P. Rakic (1979). A Golgi study of radial glial cells in developing monkey telencephalon: morphogenesis and transformation into astrocytes. Anat. Embryol., 156: 115-152.

Schmitz, B., C. Papan y J. A. Campos-Ortega (1993). Neurulation in the anterior trunk region of the zebrafish Brachydanio rerio. Roux's Arch. Dev. Biol., 202: 250-259.

Schober, A., C. R. Malz y D. L. Meyer (1993). Enzymehistochemical demonstration of nitric oxide synthase in the diencephalon of the rainbow trout (Oncorhynchus mykiss). Neurosci. Lett., 151: 67-70.

Schoenwolf, G. C. y J. L. Smith (1990). Mechanisms of neurulation: traditional viewpoint and recent advances. Development, 109: 243-270.

Schöffl, F. y H. Jockusch (1990). Genetic mapping and physical characterization of parvalbumin genes. Int. J. Biochem., 22: 1211-1215.

Schwaller, B., P. Buchwald, I. Blümcke, M. R. Celio y W. Hunziker (1993). Characterization of a polyclonal antiserum against the purified human recombinant calcium binding protein calretinin. Cell Calcium, 14: 639-648.

Shamley, D. R., L. Opperman, R. Buffenstein y F. P. Ross (1992). Ontogeny of calbindin-D28k and calbindin-D9k in the mouse kidney, duodenum, cerebellum and placenta. Development, 116: 491-496.

Sharma, S. C. (1975). Development of the optic tectum in brown trout. En: M. A. Ali (eds.): Vision in Fishes: New Approach in Research. Nueva York: Plenum Press, pp. 411-417.

Sharma, S. C. y M. Romeskie (1984). Plasticity of retinotectal connections in teleosts. En: H. Vanegas (eds.): Comparative Neurology of the Optic Tectum. Nueva York: Plenum Press, pp. 163-184.

Sharma, S. C., M. Berthoud y R. Breckwoldt (1989). Distribution of substance P-like immunoreactivity in the goldfish brain. J. Comp. Neurol., 279: 104-116.

Sohal, G. S. (1976). An experimental study of cell death in the developing trochlear nucleus. Exp. Neurol., 51: 684-698.

Solbach, S. y M. R. Celio (1991). Ontogeny of the calcium binding protein parvalbumin in the rat nervous system. Anat. Embryol., 184: 103-124. 
Spemann, H. (1938). Embryonic Development and Induction. New Haven: Yale University Press.

Sperry, R. W. (1963). Chemoaffinity in the orderly growth of nerve fiber patterns and connections. Proc. Natl. Acad. Sci. USA, 50: 703-710.

Stroh, T. y G. K. H. Zupanc (1993). Identification and localization of somatostatinlike immunoreactivity in the cerebellum of gymnotiform fish, Apteronotus leptorhynchus. Neurosci. Lett., 160: 145-148.

Subhedar, N., J. Cerdá y R. A. Wallace (1996). Neuropeptide Y in the forebrain and retina of the killifish, Fundulus heteroclitus. Cell Tissue Res., 283: 313-323.

Takeichi, M. (1990). Cadherines: a molecular family important in selective cell-cell adhesion. Ann. Rev. Biochem., 59: 237-52.

Taylor, A. N. (1974). Chick brain calcium-binding protein: comparison with intestinal vitamin-D induced calcium-binding protein. Arch. Biochem. Biophys., 161: 100-108.

Tohyama, T., V. M.-Y. Lee, L. B. Rorke, M. Marvin, R. D. G. McKay y J. Q. Trojanowski (1992). Nestin expression in embryonic human neuroepithelium and in human neuroepithelial tumor cells. Lab. Invest., 66: 303-313.

Tomoda, H. y K. Uematsu (1996). Morphogenesis of the brain in larval and juvenile Japanese eels, Anguilla japonica. Brain Behav. Evol., 47: 33-41.

Tortosa, A. y I. Ferrer (1994). Poor correlation between delayed neuronal death induced by transient forebrain ischemia, and immunoreactivity for parvalbumin and calbindin D28k in developing gerbil hippocampus. Acta Neuropathol., 88: 67-74.

Toyoda, J. y K. Uematsu (1994). Brain morphogenesis of the red sea bream, Pagrus major (Teleostei). Brain Behav. Evol., 44: 324-337.

Triller, A. y H. Korn (1978). Mise en évidence électrophysiologique et anatomique de neurones vestibulaires inhibiteurs commissuraux chez la tanche (Tinca tinca). C.R. Acad. Sci. Paris, 286: 89-92.

Turner, R. W. y L. L. Moroz (1995). Localization of nicotinamide adenine dinucleotide phosphate-diaphorase activity in electrosensory and electromotor 
systems of a gymnotiform teleost, Apteronotus leptorhynchus. J. Comp. Neurol., 356: 261-274.

Vallarino, M., D. Tranchand-Bunel, J. L. Thoumas, M. A. Masini, J. M. Conlon, A. Fournier, G. Pelletier y H. Vaudry (1995). Neuropeptide tyrosine in the brain of the African lungfish, Protopterus annectens: immunohistochemical localization and biochemical characterization. J. Comp. Neurol., 356: 537-551.

Van Brederode, J. F. M., K. A. Mulligan y A. E. Hendrickson (1990). Calcium binding proteins as markers for subpopulations of GABA-ergic neurons in monkey striate cortex. J. Comp. Neurol., 298: 1-22.

Van Den Dungen, H. M., R. M. Buijs, C. W. Pool y M. Terlou (1982). The distribution of vasotocin and isotocin in the brain of the rainbow trout. J. Comp. Neurol., 212: 146-157.

Van Veen, T., P. Ekström, L. Nyberg, B. Borg, I. Vigh-Teichmann y B. Vigh (1984). Serotonin and opsin immunoreactivities in the developing pineal organ of the three-spined stickleback, Gasterosteus aculeatus L. Cell Tissue Res., 237: 5595564.

Vanegas, H. y S. O. E. Ebesson (1976). Telencephalic projections in two teleost species. J. Comp. Neurol., 165: 181-195.

Vanegas, H., S. O. E. Ebbesson y M. Laufer (1984). Morphological aspects of the teleostean optic tectum. En: H. Vanegas (eds.): Comparative Neurology of the Optic Tectum. Nueva York: Plenum Press, pp. 93-120.

Varghese, S., S. Lee, Y. Huang y S. Christakos (1988). Analysis of rat vitamin D dependent calbindin D28k gene expression. J. Biol. Cel., 263: 9776-9784.

Vecino, E., R. Coveñas, J. R. Alonso, J. Lara y J. Aijón (1989). Immunocytochemical study of substance P-like cell bodies and fibres in the brain of the rainbow trout, Salmo gairdneri. J. Anat., 165: 191-200.

Vecino, E. y P. Ekström (1990). Distribution of met-enkephalin, leu-enkephalin, substance P, neuropeptide Y, FMRFamide, and serotonin immunoreactivities in the optic tectum of the Atlantic salmon (Salmo salar L.). J. Comp. Neurol., 299: 229-241.

Vecino, E. y S. C. Sharma (1992). The development of substance P-like immunoreactivity in the goldfish brain. Anat. Embryol., 186: 41-47. 
Vecino, E., C. Piñuela, R. Arévalo, J. Lara, J. R. Alonso y J. Aijón (1992). Distribution of enkephalin-like immunoreactivity in the central nervous system of the rainbow trout: an immunocytochemical study. J. Anat., 180: 435-453.

Vecino, E., J. García-Briñón, A. Velasco, E. Caminos y J. Lara (1993). Calbindin D28K distribution in the retina of the developing trout (Salmo fario L.). Neurosci. Lett., 152: 91-95.

Velasco, A. (1992). Glía en el Sistema Nervioso Central de teleósteos. Aportaciones morfológicas e inmunocitoquímicas. Grado de Licenciatura. Universidad de Salamanca.

Velasco, A. (1994). Glía en procesos degenerativos/regenerativos en la vía visual de tenca (Tinca tinca): estudio histoquímico e inmunohistoquímico. Tesis Doctoral. Universidad de Salamanca.

Velasco, A., E. Caminos, E. Vecino, J. M. Lara y J. Aijón (1995). Microglia in normal and regenerating visual pathways of the tench (Tinca tinca L. 1758; Teleost): a study with tomato lectin. Brain Res., 705: 315-324.

Verney, C. y P. Derer (1995). Cajal-Retzius neurons in human cerebral cortex at midgestation show immunoreactivity for neurofilament and calcium-binding proteins. J. Comp. Neurol., 359: 144-153.

Villani, L. y T. Guarnieri (1995a). Localization of NADPH-diaphorase in the goldfish brain. Brain Res., 679: 261-266.

Villani, L. y T. Guarnieri (1995b). Ultrastructural localization of NADPH-diaphorase in the goldfish brain. Brain Res., 705: 332-336.

Vogt-Weisenhorn, D. M., E. Weruaga-Prieto y M. R. Celio (1994). Localization of calretinin in cells of layer I (Cajal-Retzius cells) of the developing cortex of the rat. Dev. Brain Res., 82: 293-297.

Vogt-Weisenhorn, D. M., E. Weruaga-Prieto y M. R. Celio (1996). Calretininimmunoreactivity in organotypic cultures of the rat cerebral cortex: effects of serum deprivation. Exp. Brain Res., 108: 101-112.

Wang, D. y L. Maler (1994). The immunocytochemical localization of glutamate in the electrosensory system of the gymnotiform fish, Apteronotus leptorhynchus. Brain Res., 653: 215-222. 
Wassermann, R. H. y A. N. Taylor (1966). Vitamin D3 induced calcium-binding protein in chick intestinal mucosa. Science, 152: 791-793.

Waterman, R. E. y T. A. McCarty (1977). SEM observations of the developing teleost central nervous system. Scanning Electron Microsc., 2: 387-394.

Weld, M. y L. Maler (1992). Substance P-like immunoreactivity in the brain of the gymnotiform fish Apteronotus leptorhynchus: presence of sex differences. J. Chem. Neuroanat., 5: 107-129.

Weruaga, E. (1991). Localización inmunocitoquímica de proteínas ligantes de calcio en la retina de teleósteos. Grado de Licenciatura. Universidad de Salamanca.

Williams, R. J. P. (1992). Calcium fluxes in cells: new views on their significance. Cell Calcium, 13: 273-275.

Winsky, L. y D. M. Jacobowitz (1991). Radioimmunoassay of calretinin in the rat brain. Neurochem. Int., 19: 517-522.

Winsky, L. y J. Kuznicki (1995). Distribution of calretinin, calbindin D-28k, and parvalbumin in subcellular fractions of rat cerebellum: effects of calcium. J. Neurochem., 65: 381-388.

Winsky, L. y J. Kuznicki (1996). Antibody recognition of calcium-binding proteins depends on their calcium-binding status. J. Neurochem., 66: 764-771.

Wouterlood, F. G. y W. Härtig (1995). Calretinin-immunoreactivity in mitral cells of the rat olfactory bulb. Brain Res., 682: 93-100.

Yamada, T., P. McGeer, K. Baimbridge y E. McGeer (1990). Relative sparing in Parkinson's disease of substantia nigra dopamine neurons containing calbindinD28k. Brain Res., 526: 303-307.

Yamaguchi, T., L. Winsky y D. M. Jacobowitz (1991). Calretinin, a neuronal calcium binding protein, inhibits phosphorylation of a $39 \mathrm{kDa}$ synaptic membrane protein from rat brain cerebral cortex. Neurosci. Lett., 131: 79-82.

Yamamoto, T., L. Maler y J. I. Nagy (1992). Organization of galanin-like immunoreactive neuronal systems in weakly electric fish (Apteronotus leptorhynchus). J. Chem. Neuroanat., 5: 19-38. 
Yamamoto, N., Y. Oka, M. Amano, K. Aida, Y. Hasegawa y S. Kawashima (1995). Multiple gonadotropin-releasing hormone ( $\mathrm{GnRH})$-immunoreactive systems in the brain of the dwarf gourami, Colisa lalia: immunohistochemistry and radioimmunoassay. J. Comp. Neurol., 355: 354-368.

Yan, Y. H., J. F. Van Brederode y A. E. Hendrickson (1995). Transient colocalization of calretinin, parvalbumin and calbindin D-28K in developing visual cortex of monkey. J. Neurocytol., 24: 825-837.

Yu, M. C., E. Cho, C. B. Luo, W. W. Y. Li, W. Z. Shen y D. T. Yew (1996). Immunohistochemical studies of GABA and parvalbumin in the developing human cerebellum. Neuroscience, 70: 267-276.

Zhang, J. H., Y. Morita, T. Hironaka, P. C. Emson y M. Tohyama (1990). Ontological study of calbindin D-28k-like and parvalbumin-like immunoreactivities in rat spinal cord and dorsal root ganglia. J. Comp. Neurol., 302: 715-728.

Zielinski, B. y T. J. Hara (1988). Morphological and physiological development of olfactory receptor cells in rainbow trout (Salmo gairdneri) embryos. J. Comp. Neurol., 271: 300-311.

Zottoli, S. J., K. J. Rhodes, R. J. G. Corrodi y E. J. Mufson (1988). Putative cholinergic projections from the nucleus isthmi and the nucleus reticularis mesencephali to the optic tectum in the goldfish (Carassius auratus). J. Comp. Neurol., 273: 385-398.

Zottoli, S. J., A. P. Bentley, B. J. Prendergast y H. I. Rieff (1995). Comparative studies on the Mauthner cell of teleost fish in relation to sensory input. Brain Behav. Evol., 46: 151-164.

Zupanc, G. H. K., L. Maler y Heiligenberg (1991). Somatostatin-like immunoreactivity in the region of the prepacemaker nucleus in weakly electric knifefish, Eigenmannia: a quantitative analysis. Brain Res., 559: 249-260. 